\title{
Cooperating teaching as a professional development activity
}

Trina Lorraine Spencer

William \& Mary - School of Education

Follow this and additional works at: https://scholarworks.wm.edu/etd

Part of the Teacher Education and Professional Development Commons

\section{Recommended Citation}

Spencer, Trina Lorraine, "Cooperating teaching as a professional development activity" (2007). Dissertations, Theses, and Masters Projects. Paper 1550154168.

https://dx.doi.org/doi:10.25774/w4-8s78-f442

This Dissertation is brought to you for free and open access by the Theses, Dissertations, \& Master Projects at W\&M ScholarWorks. It has been accepted for inclusion in Dissertations, Theses, and Masters Projects by an authorized administrator of W\&M ScholarWorks. For more information, please contact scholarworks@wm.edu. 
COOPERATING TEACHING AS A PROFESSIONAL DEVELOPMENT ACTIVITY

A Dissertation
Presented to
The Faculty of the School of Education
The College of William and Mary
Of the Requirements for the Degree
Doctor of Philosophy
brina Lorraine Spencer
May 2007


Cooperating Teaching as a Professional Development Activity

Trina L. Spencer

Approved May, 2007

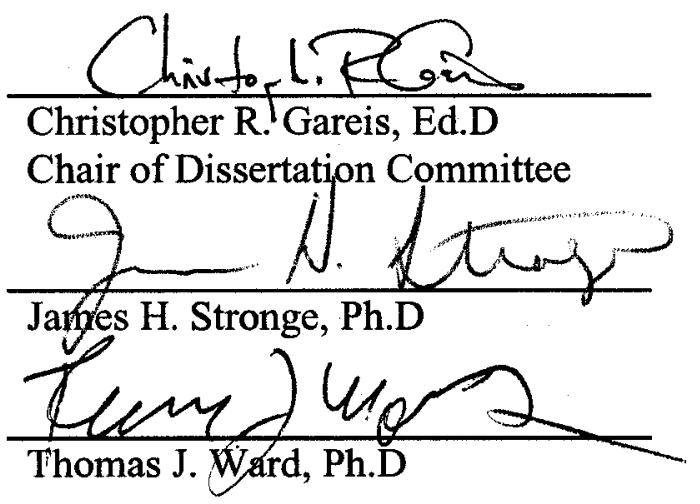




\section{DEDICATION}

This achievement was accomplished through the blessings of God and the love of a kind

and caring mother. Her perseverance, friendship, and strength of character were some of her endearing traits that will sustain her memory.

iii

Reproduced with permission of the copyright owner. Further reproduction prohibited without permission. 


\section{ACKNOWLEDGEMENTS}

"The Road Less Taken" for pursuing this degree has been filled with many blessings and happy moments. Gratitude is expressed to my dissertation committee for their expertise and guidance. As chair, Dr. Gareis' pursuit of excellence assisted me in expanding my thinking, developing a research conceptual framework, and gaining professional insight. Dr. Sronge's patience and efforts helped clarify the thoughts and ideas needed for quality research. Dr. Ward's enthusiasm and support guided the modifications of the research instrument and his knowledge expanded my statistical skills.

I am grateful for the support and kindness from Deborah Walker and the friends I have made through the School of Education.

Sincere appreciation is extended to my family and friends for their prayers, words of encouragement, understanding, and thoughtfulness.

Thanks is also extended to my dad for his love and support. 


\section{Table of Contents}

Chapter 1: Introduction

History of Professional Development 4

$\begin{array}{ll}\text { History of Student Teaching } & 7\end{array}$

$\begin{array}{ll}\text { Research Purpose and Rationale } & 10\end{array}$

$\begin{array}{ll}\text { Conceptual Framework } & 11\end{array}$

$\begin{array}{ll}\text { Research Questions } & 13\end{array}$

$\begin{array}{ll}\text { Definition of Terms } & 14\end{array}$

$\begin{array}{ll}\text { Limitations of the Study } & 14\end{array}$

Chapter 2: A Review of Literature $\quad 16$

$\begin{array}{lr}\text { Cooperating Teaching } & 17\end{array}$

Professional Development $\quad 32$

Cooperating Teaching as Professional Development 52

Chapter 3: Methodology 59

$\begin{array}{ll}\text { Participants and Setting } & 60\end{array}$

Instrument and Instrument Development $\quad 62$

$\begin{array}{ll}\text { Data Collection } & 73\end{array}$

$\begin{array}{ll}\text { Data Analysis } & 74\end{array}$

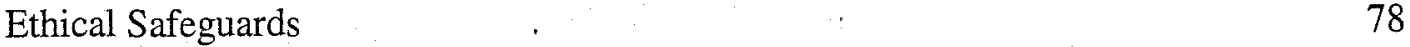

$\begin{array}{ll}\text { Chapter 4: Results } & 79\end{array}$

$\begin{array}{ll}\text { Return Rate and Demographic Information } & 79\end{array}$

Analysis of Research Questions $\quad 85$

$\begin{array}{ll}\text { Primary Research Question } & 85\end{array}$ 
Research Question 1

Research Question 2 88

$\begin{array}{ll}\text { Research Question } 3 & 90\end{array}$

$\begin{array}{ll}\text { Research Question } 4 & 91\end{array}$

Research Question 5 92

Research Question 6 95

$\begin{array}{ll}\text { Research Question } 7 & 96\end{array}$

Chapter 5: Summary, Discussion, and Recommendations 101

$\begin{array}{ll}\text { Summary of Findings } & 101\end{array}$

$\begin{array}{ll}\text { Discussion of Findings } & 103\end{array}$

$\begin{array}{ll}\text { Conceptual Framework } & 104\end{array}$

Cooperating Teacher Demographics and Experience 105

$\begin{array}{ll}\text { Cooperating Teacher Preparation } & 107\end{array}$

Cooperating Teacher Grade Level Assignment 109

Relating Findings to Other Research $\quad 109$

$\begin{array}{ll}\text { Summary of Conclusion } & 113\end{array}$

$\begin{array}{ll}\text { Areas of Further Attention } & 114\end{array}$

$\begin{array}{ll}\text { Future Research } & 115\end{array}$

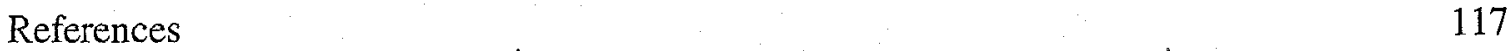

$\begin{array}{ll}\text { Appendices } & 129\end{array}$ 


\section{LIST OF TABLES AND FIGURES}

$\begin{array}{ll}\text { Figure 1. Conceptual framework } & 11\end{array}$

Table 1. Demographic information on cooperating teachers 24

Table 2. National Staff Development Council (NSDC) Standards 36

Table 3. Features of professional development 40

Table 4. Professional development evaluation 51

Table 5. Cooperating teacher research that addresses professional development 53

$\begin{array}{ll}\text { Table } 6 . \quad \text { Cooperating teachers by grade level } & 61\end{array}$

Table 7. Clinical faculty teachers by grade level 61

$\begin{array}{lll}\text { Table 8. Cooperating teachers and clinical faculty teachers } & 62\end{array}$

Table 9. Demographic information on cooperating teachers by school district 62

Figure 2. Standards Assessment Inventory (SAI)-Context Category 66

Figure 3. Standards Assessment Inventory (SAI)-Process Category 67

Figure 4. Standards Assessment Inventory (SAI)-Content Category 67

Figure 5. Logic model on converting the Standards Assessment Inventory survey 68 items

$\begin{array}{lll}\text { Table 10. Examples of original and modified survey items } & 69\end{array}$

Table 11. Number of converted and not converted survey items $\quad 70$

Figure 6: Modified Standards Assessment Inventory (SAI)-Context Category 71

Figure 7. Modified Standards Assessment Inventory (SAI)-Process Category 71

Figure 8. Modified Standards Assessment Inventory (SAI)-Content Category 72

Table 12. Timeline for data collection $\quad 75$

Table 13. Data analysis by research sub-question 76 
Table 14. Data analysis by participant demographics and NSDC standards

Table 15. Frequency and percentages of original sample size and response rate by grade level

Table 16. Frequency and percentages of original sample size and response rate by gender

Table 17. Frequency and percentages of participants by gender, ethnicity, age, highest degree, and years of teaching

Table 18. Frequency and percentages of the student teachers supervised by the participants

Table 19 Frequency and percentages of participants by cooperating teacher preparation

Table 20 Descriptive statistics for professional development

Table 21 Classifications for NSDC category and standard averages

Table 22 Descriptive statistics for context category and standards

Table 23 Descriptive statistics for process category and standards

Table 24 Descriptive statistics for content category and standards

Table 25 Analysis of variance for grade levels (elementary, middle, and high)

Table 26 Descriptive statistics for process category by grade level (elementary, middle, and high)

Table 27 Summary of stepwise multiple regression analyses for cooperating teacher 95 experience

Table 28 Summary of stepwise multiple regression analysis for cooperating teacher preparation 
Table 29 Summary of stepwise multiple regression analysis for demographics

Table 30 Summary of stepwise multiple regression analysis for demographics

Table 31 Descriptive statistics of clinical faculty and cooperating teachers

Table 32 Analysis of variance of clinical faculty and cooperating teachers

Table 33 Cooperating teacher studies and their alignment to the National Staff Development Council (NSDC) Standards 


\section{LIST OF APPENDICES}

Appendix A: Original and Modified Standard Assessment Inventory Items 126

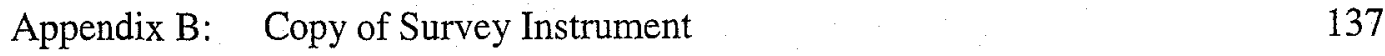

$\begin{array}{lll}\text { Appendix C: } & \text { Pre-Contact Letter } & 143\end{array}$

Appendix D: Survey Cover Letter and Survey Reminder 145

$\begin{array}{ll}\text { Appendix E: } \quad \text { Survey Item Results } & 147\end{array}$ 
COOPERATING TEACHING AS A PROFESSIONAL DEVELOPMENT ACTIVITY

\section{ABSTRACT}

This study examined cooperating teachers' perceptions of how student teacher supervision is aligned with the standards of the National Staff Development Council (NSDC). The conceptual framework of this research advanced that serving as a cooperating teacher is equivalent to a professional development activity. The researcher adapted an instrument from the NSDC to measure cooperating teachers' perceptions in grades $\mathrm{K}-12$. The survey was completed by 181 out of the 287 sample population. The research findings indicated that cooperating teaching is a professional development activity that aligned with the standards of the NSDC. This role used the three categories needed for effective professional development: context, process, and content. Clinical faculty and mentorship training are methods of cooperating teacher preparation that significantly predicted how cooperating teachers viewed this role as a professional development activity. Clinical faculty trained teachers had higher perceptions of supervising student teachers as a professional development activity than non-trained clinical faculty teachers. Other findings revealed that the number of experiences in supervising student teachers was a significant predictor of cooperating teachers' perceptions.

TRINA LORRAINE SPENCER

PROGRAM IN EDUCATIONAL POLICY, PLANNING, AND LEADERSHIP THE COLLEGE OF WILLIAM AND MARY IN VIRGINIA 
Cooperating Teaching as a Professional Development Activity 


\section{Chapter 1}

Teacher quality and professional development are interconnected issues which have grown in importance through educational policies, reforms, and movements. Our national, state, and local political leaders continue to launch initiatives that create change in what children learn and how they are taught. The success of these initiatives depends on teacher quality and effectiveness. Professional development makes a positive impact on a teacher's ability to carry out the new and continuing demands of educational reform (Garet, Porter, Desimone, Birman, \& Yoon, 2001).

"High quality professional development is a central component in nearly every modern proposal for improving education" (Guskey, 2002b, p. 381). As our knowledge base continues to expand, new types of expertise will be needed to keep pace. All educational levels need professional development to help them adapt to their new roles, such as encouraging parental involvement, shared decision making, and implementing the new policies that restructure the organization. Educational reforms require us to rethink our roles and responsibilities (Guskey, 2002b).

Professional development is in an era that is moving away from activities that are disconnected from the classroom to experiences that promote student learning needs (Sparks \& Hirsh, 1997). Our changing view of professional development also requires a shift in how educators view their roles. Increasing teacher growth and capacity can occur through a variety of roles such as presenter, school board advisory member, and gradelevel chair person. Formal and informal positions within a school setting that involve a 
willingness to collaborate can enhance a teacher's professional growth (Speck \& Knipe, 2001).

Being a cooperating teacher is another role that can increase an individual's professional growth. However, this role is generally unrecognized as a professional development activity (Ganser \& Wham, 1998). On the other hand, researchers have concluded that cooperating teaching impacts a person's personal and professional development (Holm, 2004; Landt, 2002).

'The cooperating teacher's role has been cited as influential, important, and essential to the teaching experience of student teachers" (Glickman \& Bey, 1990, p 558). Cooperating teachers provide a positive and supportive classroom environment that nurtures the development of student teachers (Conner \& Killmer, 2001; Ganser \& Wham, 1998; Woolley, 1997). They also provide a pivotal connection between university coursework and field experiences (Ganser, 1996).

This descriptive study determined the degree to which serving as a cooperating teacher is a professional development activity that aligned with the National Staff Development Council (NSDC) standards. This study was based on the concept that cooperating teaching is equivalent to a professional development activity. To explore the foundation of this study, this chapter will trace the progression of professional development, the history of student teaching, and present this study's conceptual framework. 


\section{History of Professional Development}

The launch of the Russian satellite, Sputnik, in 1957 was one of the first events that created interest for our public schools, especially in the subject areas of math and science. The Defense Fund Act of the 1960s generated professional development opportunities to help enhance curriculum and instructional strategies. Summer training programs were also enacted to increase teacher knowledge of current research and subject matter (Speck \& Knipe, 2001).

In the 1970s, staff development activities such as conferences, keynote speakers and workshops continued to increase. They offered a wide range of information on curriculum and instruction (Speck \& Knipe, 2001). These types of programs were scheduled for a short duration (less than a day) and provided basic information about a

new educational topic (Bellanca, 1995). Professional development programs attempted to match "how to teach" with "what to teach." Checklists, lesson plans, and models of specific behaviors were developed and presented to construct effective teaching behaviors (Borich; 2000; Hunt, Touzel, \& Wiseman, 1999; McEwan, 2002).

The terms professional development and staff development will be interchanged throughout this document because these words have similar meanings. However, in the 1980s, the term "professional development" began to replace "staff development." Staff development was becoming linked to isolated experiences that were meant to "fix" the teacher's behavior, while professional development was associated with experiences that are a part of a lifelong learning process (Bellanca, 1995).

The educational research of the 1980 s focused on how teacher knowledge is learned and applied. Workshops reflected this trend by presenting information on content 
knowledge and instructional strategies. The concept of "coaching" successful teaching behaviors began. The "coach" developed the teacher's understanding of the new strategy and gave feedback on how the learning was being implemented (Speck \& Knipe, 2001). Congress enacted the Improving America's School Act of 1994. This act recognizes the importance of professional development for achieving the goals of school readiness, parental participation, adult literacy, safe and drug-free schools, teacher education and student achievement. Title II of this legislation, Dwight D. Eisenhower Professional Development Program, outlined strategies for achieving high quality professional development. These activities:

- Must focus on teaching and learning

- Must focus on a disciplined-base of knowledge and effective subject-specific pedagogical skills

- Require time for teachers to incorporate into their existing practices

- Have knowledge and strategies for serving populations that have historically lacked access to equal opportunities for advaniced learning and career advancement

- Use teachers and, where appropriate, administrators, pupil services personnel and parents in developing and implementing activities (U.S. Congress, 1994).

. The professional development efforts of the 1990s also recognized the importance of the organization in transforming schools. A teacher's ability to improve his or her performance is connected to organizational support and services. Organizational changes and individual learning are both needed to support and sustain school reforms (Speck \& Knipe, 2001). 
The decade of the 1990s also witnessed professional development activities for the school staffs and saw a shift in how professional development was being evaluated. As an outgrowth of viewing the school organization as an interconnected group, professional development activities were now being extended to principals, teachers and staff and were seen as a necessary process for improving student outcomes. Evaluating professional development activities shifted from using a teacher's "happiness" quotient to measure success to using student outcomes to measure success (Speck \& Knipe, 2001).

Evaluating professional development involves collecting and analyzing information on five levels: participant reactions, participant learning, organizational support and change, participants' use of new knowledge and skills, and student learning outcomes. The information gained at each level indicates how a program's design, delivery, and content can be improved. However, when planning a professional development activity, one uses these levels in reverse. For example, planning begins with identifying the student learning outcomes and progresses to deciding which strategies will lead to your desired student outcomes (Guskey, 2002a).

In 2002, President Bush's No Child Left Behind (NCLB) legislation was enacted by Congress and increased our view of high quality professional development. High quality professional development is aligned with state standards and assessments and has sustained and intensive classroom focus. Professional development activities should extend beyond one-day workshops and include activities that increase teacher academic knowledge, provide technology training, and assist teachers in gaining instructional strategies. 
Professional development efforts were once viewed as fragmented activities that had limited impact on classroom life. These activities were derived from adult needs, emphasized basic instructional skills, and used professional developers for delivery and implementation. New trends suggest that these efforts should be a part of a school or school district's strategic plan that directly effect classroom learning. Professional development should be based on student learning needs, accentuate basic and content specific skills, and use multiple educators for implementation and development (Sparks \& Hirsh, 1997).

Quality professional development activities engage teachers in various roles and responsibilities. These efforts should be centered on observation, assessment and reflection and sustained over a period of time. These activities must engage teachers in concrete teaching tasks. Collaboration is needed to foster professionalism, commitment, and respect for learning (Darling-Hammond \& McLaughlin, 1995; Kent, 2004).

Supervising student teachers provides one potential avenue for improving an individual's professional growth and practice. This role allows teachers the opportunity to reflect daily and collaborate, and is connected to their employment. Guiding student teachers helps cooperating teachers to look critically at what is occurring in their classroom (Holm, 2004).

\section{History of Student Teaching}

The training and supervision of student teachers has evolved from an apprenticeship model to an experience that integrates fields of related study and technology. Although schools have educated pupils for over 4,000 years, the interest in 
educating and training teachers has only existed in the past 300 years (Guyton \& McIntyre, 1990).

In the late 1700 s, Jean Bapiste de la Salle, the Father of Student Teaching founded the first normal school in France (Guyton \& McIntyre, 1990). The first normal school in the United States was established in 1839 in Lexington, Massachusetts (Garland \& Shippy, 1995). By the mid 1800s, the normal school model had replaced the apprenticeship model for training student teachers (Guyton \& McIntyre, 1990). In the apprenticeship model, student teachers worked with experienced teachers to learn the skills of teaching. Student teachers were expected to learn and mimic the experienced teachers' patterns and then teach their students in the same manner (Garland \& Shippy, 1995).

Normal schools were the first to offer specific academic training for teacher education. They provided student teachers subject knowledge and the techniques for managing instruction (Feisman-Nemser, 1990). When secondary education expanded, normal schools offered a two-year course of study and required a high school diploma for admission (Feisman-Nemser, 1990). A liberal arts degree was the only requirement for secondary teachers (Guyton \& McIntyre, 1990). Over time, the expansion of secondary education caused states to create teacher colleges. Teacher colleges began to replace normal schools at the beginning of the $20^{\text {th }}$ century (Garland \& Shippy, 1995).

In teacher colleges, student teachers modeled and practiced the methods taught by the professors and modeled by the classroom teachers. However, student teaching was primarily a vocationally trained practice until the 1920s (Guyton \& McIntyre, 1990). Between the 1920 and 1940 , states started to require student teaching and courses as 
prerequisites to teacher certification. In 1928, the American Association for Teacher Colleges (AATC), later renamed as the American Association of Colleges for Teacher Education (AACTE), required member institutions to have 90 minimum clock hours for student teaching and published student teacher guidelines and standards. The Association for Student Teaching (ATC) also contributed to the advancement of student teaching by publishing books, research, and newsletters on this topic (Guyton \& McIntyre, 1990). By the 1940s student teachers received their opportunities for teaching, observation, demonstration, and participation in laboratory schools. The primary purpose for laboratory schools on the college and university campuses was to serve teacher education. These schools were staffed by experienced and qualified teachers who guided the student teachers' experiences in a controlled setting (Garland \& Shippy, 1995; Stallings \& Kowalski, 1990). Prior to the 1940s, laboratory schools were expected to focus on research activities intended to improve preservice teacher experiences. Laboratory schools were established at the beginning of the $20^{\text {th }}$ century through the influence of Columbia University and the University of Chicago. John Dewey postulated that teaching laboratories would resemble the work of scientific laboratories. Teaching laboratories would verify, test, or criticize theoretical statements and would provide information to add to the facts and principles of education (Stallings \& Kowalski, 1990).

In the 1950 s, colleges and universities began to use public schools for field experiences because the laboratory schools were becoming dissimilar to public schools and could not accommodate the large number of student teachers (Garland \& Shippy, 1995). Student teachers' experience also shifted from practice teaching to studying the 
act of teaching. Prospective teachers were now considered students of teaching (Garland \& Shippy, 1995).

In the 1960s it became evident that colleges/universities and schools needed to develop a closer partnership and relationship due to the high number of student teachers that were completing their field experiences in the public schools. The term cooperating teacher reflects the emphasis on the cooperation between the public schools and colleges/universities. It also signified the importance of a joint responsibility in educating the student teacher, and this term had a positive connotation over the terms critic teacher and supervising teacher (Garland \& Shippy, 1995).

This history of student teaching reveals that experienced teachers have been a part of developing student teachers' skills and knowledge for the history of teacher training. The title of these teachers has changed from critic or master teacher to supervising teacher to cooperating teacher. Although we have rich knowledge about how student teacher experiences have developed, we have limited research on cooperating teachers' experiences (Clarke, 2001). Zeichner, Liston, Mahilos, and Gomez (as cited in Clarke, 2001) were the first to raise the issue of studying cooperating teachers' experiences in 1987. Glickman and Bey (1990) described the research findings on how cooperating teachers prepare to function in this role in the late 1980s. This indicates that we have less than 20 years of information on role that spans over 300 years. Additional and current research is needed to describe the experiences of cooperating teachers.

\section{Research Purpose and Rationale}

The purpose of this study was to describe how serving as a cooperating teacher aligned with the professional development standards of the National Staff Development 
Council (NSDC). The research on cooperating teachers is limited, especially on how this role can affect a teacher's individual growth (Kiraz 2004; Landt, 2002). Studying how cooperating teaching creates professional growth gives us insight into teacher development, which is an important element for improving schools (Ganser 1997). Validating this role as professional development activity will help teachers and administrators recognize this experience as another opportunity to maximize teacher learning and growth (Holm 2004; Landt, 2002).

Figure 1

Conceptual Framework

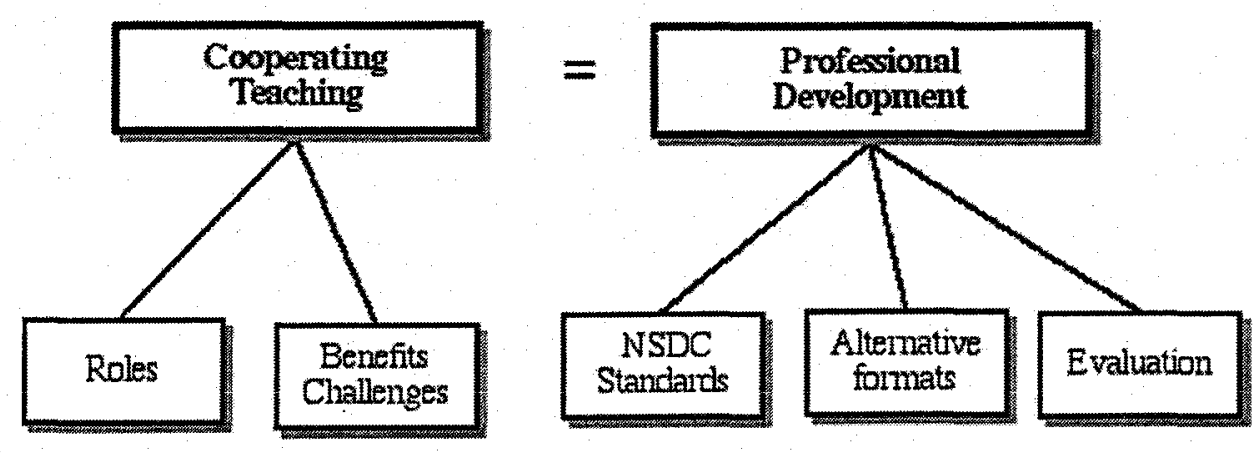

Conceptual Framework

Cooperating teaching is a professional development activity (see Figure 1).

Cooperating teaching should be considered an alternative format of professional development. Alternative formats engage teachers in real issues and questions related to. student learning, content, and instruction. Cooperating teachers are certainly involved in tasks with student teachers that are connected to student knowledge, achievement, and instruction. Through these roles, mentor, assessor, model, guide, and coach (Ganser \& 
Wham, 1998 \& Portner, 2003), cooperating teachers pursue their ultimate goal of helping pre-service teachers transition into the world of teaching (Ganser, 1996).

The role of cooperating teacher role does offer benefits and challenges. It offers benefits such as increasing an individual's enthusiasm for teaching and gaining instructional strategies (Kosela \& Ganser, 1995; Landt, 2002). However, the challenges of this responsibility include having a lack of clear guidance and direction from the student teacher's university or college and having different philosophies and cultural beliefs than the student teacher (Kahn, 2001; Koerner, 1992). The benefits and challenges both lead to an individual's professional growth.

As defined by the National Staff Development Council (NSDC), professional development incorporates 12 standards that are divided into the three categories of context, process, and content (NSDC, 2001). These standards represent the best practices of professional development and are based on research as well as a broad range of expert opinion (Guskey 2002). Serving as a cooperating teachers, involves the context, process, and content variables that are described in these standards.

Finally, the evaluation of professional development is needed to make improvements and judgments about a program based on clear objective and goals (Guskey, 2000). This information from program evaluations reveals strengths and weaknesses and can be used to help leaders justify a program's existence (Kirkpatrick, 1996). 
Research Questions

Primary Question: Using the National Staff Development Council (NSDC) standards as a survey framework, how do cooperating teachers perceive student teacher supervision as a professional development activity?

Research Questions

1. Does the role of cooperating teaching support the context standards needed for professional development?

2. Does the role of cooperating teaching support the process standards needed for professional development?

3. Does the role of cooperating teaching support the content standards needed for professional development?

4. To what degree do cooperating teachers at different grade levels (elementary, middle, and high) have different perceptions of student teacher supervision as a professional development activity?

5. What is the relationship between cooperating teachers' experience levels (degree earned, years of full time teaching, and number of student teachers supervised) in their perceptions of student teacher supervision as a professional development activity?

6. What is the relationship between cooperating teachers with different preparation (no training, informal meeting, student teacher orientation, mentorship training, or clinical faculty training) in their perceptions of student teacher supervision as a professional development activity? 
7. What demographic factors help predict how cooperating teachers perceive student teacher supervision as a professional development activity?

Definition of Terms

This section provides a brief explanation of the terms that were presented in the preceding chapters.

\section{Cooperating teacher}

An experienced teacher who supervises pre-service teachers by monitoring their performance and providing them the opportunity to plan and conduct student learning activities in a school setting.

Clinical faculty teacher

Cooperating teachers who have completed a supervision training program or course offered through this university or another university

\section{Student teacher}

An individual who is a full-time intern in the field-based portion of a teacher preparation program that extends over a predetermined length of time. This person is also called a pre-service teacher.

\section{Professional development}

An ongoing process that continuously improves educator knowledge through activities that causes critical reflection.

$$
\text { Limitations of the Study }
$$

The following limitations apply to the results of this study:

1. The participants represented a convenience sample, which may cause the results to not be generalizable to all cooperating teachers. 
2. The sample population was restricted to cooperating teachers who have had one or more student teachers within the past five years.

3. The participants represented a limited geographic area which may limit generalizing these results to other areas.

4. The survey information was determined through self-report methods and may not reflect an individual's actual feelings or thoughts. 


\section{Chapter II: Literature Review}

Dedicated teachers pursue a variety of roles that demonstrate their commitment to the education profession. These responsibilities include, but are not limited to, grade level or department chair person, school improvement team member, and member of a school district's curriculum committee. Serving as a cooperating teacher is one of the most significant ways to contribute to the profession (Ganser, 2002).

Cooperating teachers accept the responsibility of guiding preservice teachers or student teachers through the field-based portion of a teacher preparation program (Rudney \& Guillaume, 2003). Each year thousands of cooperating teachers share their time and talent with student teachers. After the student teacher leaves, Tatel (1994) raises the following questions, "Was this experience instructive for the cooperating teacher? Is this effective professional development? When they look back upon the experience, do cooperating teachers think that they profited from supervising a student teacher?" (p. 1).

Although cooperating teachers are one of the most important components in the teacher preparation program, there is limited research on their experiences and how this role impacts their professional development (Clarke, 2001; Koskela \& Ganser, 1995). The purpose of this study is to determine the degree to which serving as a cooperating teacher is a professional development activity that aligns with the National Staff Development Council (NSDC) standards. The literature review that follows will examine the nature of being a cooperating teacher, professional development, and cooperating teaching as professional development. 


\section{Cooperating Teacher}

Cooperating teachers play a significant role in the preparation, behaviors, and attitudes of student teachers by shaping their pedagogical choices and thought processes (Glickman \& Bey, 1990; Osunde, 1996). Cooperating teachers are expected to display excellent classroom expertise and be superior teaching role models. Student teachers learn and mirror their teaching strategies and discipline techniques through this individual's actions (Rudney \& Guillaume, 2003).

Student teaching is the field-based portion of the teacher preparation program that extends over a given time frame. This experience is highly valued by educators because it initiates the beginning phase of teacher development (Ganser, 1997). Cooperating teachers are the key element in teacher preparation because they provide "real-life" ventures into the teaching profession and transition future teachers from "students of teaching" to "teachers of students" (Ganser, 1996; Kahn, 2001).

Cooperating teachers use various roles to help student teachers transition into their teaching careers. Cooperating teachers are offered an array of avenues that prepare them for responsibilities and challenges. Supervising student teachers also presents personal and professional benefits. The roles, preparation, challenges, and benefits of cooperating teaching will be described in the next sections.

\section{Roles and Responsibilities}

Cooperating teachers have an assortment of roles and responsibilities. They use their previous experiences and memories as novice teachers to help define their views on this role (Koerner, 1992). Cooperating teachers feel that this role validates their experiences and provides a chance for thinking and reflecting on teaching. This role 
raises the enthusiasm for teaching and increases a person's awareness of innovative instructional and management techniques (Koskela \& Ganser, 1995).

Evidently, the research on the role of cooperating teachers shows their obligation to model, guide, and facilitate. As models, they demonstrate instructional strategies and techniques. Modeling assists student teachers in mastering teaching skills and developing an understanding of the teaching process (Connor, Killmer, \& Mckay, 1993; Koskela \& Ganser, 1995; Ganser \& Wham, 1998). Cooperating teachers are concerned about being good role models, are introspective, and are anxious about their performance (Caruso, 1998; Glickman \& Bey, 1990).

In addition to modeling, cooperating teachers guide and develop the student teacher competencies in lesson planning, classroom management, lesson delivery and any new task of expected behavior (Glickman \& Bey, 1990; Weasmer \& Woods, 2003). Disseminating directions, constructive criticism, and ideas for student learning characterize the actions for guiding student teachers. As facilitators, cooperating teachers encourage, motivate, nurture, and provide the support that helps student teachers gain confidence (Caruso, 1998; Koskela \& Ganser, 1995; Ganser \& Wham, 1998).

An another study concluded that cooperating teachers felt that their role was to help, guide, advise, and encourage student teachers. Cooperating teaching involves the tasks of creating a relationship with the student teacher and exchanging ideas and feedback on lessons. Cooperating teachers should integrate student teachers into the school and school district by encouraging them to attend staff meeting and activities. Cooperating teachers believed that it was their duty was to organize the practicum experience to enable student teachers to progress towards full-time teaching and to 
provide opportunities for student teachers to practice their instructional delivery (Boudreau, 1999).

Cooperating teachers' duties carry rights and responsibilities. They are responsible for providing honest and caring feedback, hearing different viewpoints, and granting freedom for student teachers to develop their teaching style. Cooperating teachers have the right to expect professional behavior and high-quality instructional practices from their student teachers. Other rights include obtaining assistance from university and school building personnel and administrators (Rudney \& Guillame, 2003).

Effective cooperating teacher research shows that they provide classroom experiences in a flexible atmosphere that is a psychologically safe for the student teacher. They also display a caring attitude, establish a good working rapport and have positive communication skills. Effective cooperating teachers provide constructive criticism and experiences that enable student teachers to integrate theory into practice and extend textbook learning (Connor \& Killmer, 2001; Kahn, 2001; Ganser, 1997; Ganser, 2002; Ganser \& Wham, 1998; Sudzina, Giebelhaus, \& Coolican, 1997; Woolley, 1997).

Effective cooperating teachers provide helpful feedback, shares ideas and methods for planning and management, and have positive communication skills. Other qualities include providing nurture and support, and allowing the freedom to try new endeavors (Connor \& Killmer, 2001; Connor, Killmer, \& Mckay, 1993; Kahn, 2001; Woolley, 1997).

Cooperating teachers as mentors

Being a cooperating teacher involves mentoring a student teacher's growth and development. Broadly defined, a mentor, formally or informally, assists a teacher's 
professional development. Cooperating teachers are usually deemed the primary mentors to preservice teachers (Rudney \& Guillaume, 2003). Trubowitz (2004) states that "mentoring is a process of enabling another to act and of building on the mentee's strengths, rather than one of imposing ideas and information from the outside" (p. 59). Alleman, Cochran, Doverspike, and Newman (as cited in Giebelhaus \& Bowman, 2002) state that, "mentoring is a relationship in which a person of greater rank or expertise teachers, guides, and develops a novice" (p. 1). Based on these definitions, mentoring is a process that involves a relationship with another individual who has more knowledge. The person with the greater knowledge builds on the person's strengths and guides his or her development.

There are similar traits between being a mentor and serving as a cooperating teacher. Ganser (1997) surveyed teachers who have served both as a mentor and a cooperating teacher. Participants felt that both roles were influential for personal and professional reasons and were a critical function in teacher induction. Each role involves promoting reflection, teaching instructional techniques and strategies, and reinforcing approaches to classroom management. This study concluded that most teachers would benefit by serving in either role.

There are also distinct differences in the responsibilities of mentors and cooperating teachers. Cooperating teachers support student teachers' development and are expected to evaluate their performance with the support of a university supervisor. The cooperating teacher-student teacher relationship has been called an unbalanced relationship because of the cooperating teachers' supervisory responsibility of evaluation (Rudney \& Guillaume, 2003). In contrast, mentors nurture the development of first-year 
or novice teachers. Although mentors may observe and assess their mentees' strengths and weaknesses, mentors are supporters not evaluators. Evaluating new teachers' performances are the duty of a principal or assistant principal (Boreen, Johnson, Niday, \& Potts, 2000).

Mentoring student teachers is one of the primary roles for cooperating teachers. It is a collaborative effort and a process that requires a commitment from both cooperating teachers and student teachers. Mentoring should be viewed as a serving relationship that implies an equal and mutual partnership. However, poor student teacher-cooperating teacher relationships can attribute to a failed student teaching experiences (Awaya, McEwan, Heyler et. al., 2003; Portner, 2003; Sudzina, Giebelhaus, \& Coolican, 1997). Cooperating teachers have mentoring roles that are slightly different from the roles that were described earlier. Cooperating teacher mentor roles describe a personal and interactive process and relationship between the cooperating teacher and student teachers. These roles and process are titled relating, assessing, coaching, and guiding. In the first step, relating, cooperating teachers and student teachers form and develop a relationship that is built on trust, respect, and professionalism and mutual concern (Portner, 2003). As the relationship develops, trust increases and then there is a greater focus on teaching and learning (Sudzina, Giebelhaus, \& Coolican, 1997).

Cooperating teachers are responsible for assessing the strengths and weaknesses of student teachers by gathering and analyzing information. The role of assessing also involves obtaining resources to share with the student teacher on these and other areas (Portner, 2003). Topics of student teacher concern may include classroom management 
skills, instructional skills, and knowledge of school policies and procedures (Rudney \& Guillaume, 2003).

As coaches, cooperating teachers use strategies to help foster student teachers' confidence. Successful coaches help by clarifying the "what and how" of teaching, and developing their ability to carry out choices that will improve past performances (Portner, 2003).

Systematically guiding student teachers towards self-reliant behaviors is part of being a cooperating teacher. Guiding behavior uses the roles of assessing, coaching, and relating. Cooperating teachers assess the student teachers' motivation and then determines which skill (relating or coaching) is the most appropriate for helping them make more autonomous decisions (Portner, 2003).

The cooperating teachers' role as mentor reveals some of their daily tasks and experiences. Their classroom and background experiences are factors that guide their experience with student teachers. General descriptions of cooperating teachers' background and qualifications will be the topic of the next section.

\section{Cooperating teachers' backgrounds}

Cooperating teachers have different backgrounds and qualifications. These qualifications vary across the United States. They can consist of a combination of teaching experience, advanced degree, and training through seminars, courses or workshops (Ganser, 2002). Some suggest that teaching experience and teacher personality are the most important selection criteria. This is preceded by excellent teaching and a willingness to work diligently with a student teacher (Clarke, 2001). Some colleges or universities have specific requirements, such as having a minimum of 3 years 
teaching experience and a teaching license in the area of study (Gibbs, 1994; College of William and Mary, 2005). Other requirements may include a letter of recommendation from a principal or designee (College of William and Mary, 2005) or attendance at a supervision orientation (Gibbs, 1994).

Based on the research of the American Association of Colleges from Teacher education (AACTE) in 1990 (as cited in Clarke, 2001), 67\% of cooperating teachers are female and $96 \%$ are white. They have teaching experience that averages 16 years and are in their mid-40s. Fifty percent of them have a master's degree and $10 \%$ have advanced degrees.

Survey results of cooperating teachers from Canada show another demographic profile. Fifty-seven percent of cooperating teachers are males and $43 \%$ are females. The average male age is 44 and the average female age is 43 . Cooperating teachers are twice as likely to have a master's degree as non-cooperating teachers (Clarke, 2001).

Other research results assist in providing a demographic profile. Ganser's (1997) study of cooperating teachers consisted of a sample that was $79 \%$ male and $21 \%$ female. Seventy-three percent had masters' degrees, 21 was the average for years of teaching experience, and the seven was the average number of supervised student teachers. Table 1 represents the demographic information that was found in other studies. 
Table 1

Demographic information on cooperating teachers

\begin{tabular}{|c|c|c|c|c|c|}
\hline $\begin{array}{l}\text { Author } \\
\text { Year }\end{array}$ & $\begin{array}{l}\text { Number of student } \\
\text { teachers supervised }\end{array}$ & $\begin{array}{l}\text { Years of } \\
\text { teaching } \\
\text { experience }\end{array}$ & Race & Gender & Highest degree \\
\hline $\begin{array}{l}\text { Ganser } \\
1997\end{array}$ & Average 7 & Average 21 & $\begin{array}{l}\text { Majority } \\
\text { Caucasian }\end{array}$ & $\begin{array}{l}\text { Majority } \\
\text { male }\end{array}$ & $\begin{array}{l}\text { Majority } \\
\text { Master's degree } \\
(72 \%)\end{array}$ \\
\hline $\begin{array}{l}\text { Holm } \\
2004\end{array}$ & $\begin{array}{l}\text { Range } \\
1 \text { to } 9\end{array}$ & $\begin{array}{l}\text { Range } \\
3 \text { to } 11 \text { plus }\end{array}$ & $*$ & $*$ & $\begin{array}{l}\text { Majority } \\
\text { Master's degree } \\
(54 \%)\end{array}$ \\
\hline $\begin{array}{l}\text { Tatel } \\
1996\end{array}$ & $\begin{array}{l}\text { Range } \\
1 \text { to } 15\end{array}$ & $\begin{array}{l}\text { Range } \\
5 \text { to } 37\end{array}$ & $\begin{array}{l}\text { Majority } \\
\text { Caucasian }\end{array}$ & $\begin{array}{l}\text { Majority } \\
\text { female }\end{array}$ & $*$ \\
\hline $\begin{array}{l}\text { Landt } \\
2002\end{array}$ & $\begin{array}{l}\text { Range } \\
1 \text { to } 34\end{array}$ & $\begin{array}{l}\text { Range } \\
8 \text { to } 34\end{array}$ & $*$ & $*$ & $\begin{array}{l}\text { Majority } \\
\text { Master's degree } \\
(60 \%)\end{array}$ \\
\hline $\begin{array}{l}\text { Kiraz } \\
1997\end{array}$ & $\begin{array}{l}\text { Range } \\
1 \text { to } 15\end{array}$ & $\begin{array}{l}\text { Range } \\
2 \text { to } 40\end{array}$ & $*$ & $*$ & $*$ \\
\hline
\end{tabular}

* Information was not provided

Based on the information in Figure B and the preceding paragraphs, cooperating teachers are more likely to be Caucasian females with masters degrees. Their years of teaching experience ranges from three to 40 years. The number of supervised student teachers range from one to 34 . Background experiences and qualifications are important factors for guiding preservice teachers. However, cooperating teachers need opportunities that prepare them for this role.

Cooperating teacher preparation

Ramanathan and Wilkins-Canter (1997) comment that preparing cooperating teachers should be placed in the broader context of their professional development. 
Cooperating teachers need a forum to share opinions and ask questions on the field experiences of student teachers. These discussions help to nurture a deeper understanding of their expectations and responsibilities. However, there is a general a lack of sufficient preparation for cooperating teachers. Preparation helps cooperating teachers in providing specific, objective, and written feedback (Kent, 2001). It can prevent them from having unrealistic student teacher expectations and being hesitant about giving feedback (Giebelhaus \& Bowman, 2002).

Cooperating teachers can have a variety of ways to prepare for this experience that vary with time and intensity. This range can progress from reading a student teacher manual to attending a class on supervision skills. Reviewing a student teacher handbook may take one hour as opposed to taking a graduate-level supervision course which may last 10 or more weeks. Mentor training and student teacher orientation are other avenues for cooperating teacher preparation.

\section{Student teacher handbook or other written materials.}

Some universities or colleges prepare cooperating teachers by giving them a handbook or guide that describes their roles and responsibilities in student teachers' field experiences. This guide may incorporate student teacher evaluation forms but typically do not provide strategies on conferencing and collaboration skills (Ramanathan \& Wilkins-Canter, 1997). Some handbooks provide descriptive information on the student teaching competencies and the goals of the student teaching practica. They can delineate cooperating teacher-student teacher procedures, policies and guidelines on appearance, school placements, handling confidential information, lesson planning, and pacing of the field experience (College of William and Mary, 2005). 


\section{Orientation meetings.}

Orientation or introductory meetings sponsored by a university or college are used to acquaint cooperating teachers with their supervision roles, responsibilities, and the purposes of the student teaching field experience. These meetings may present the expectations of the teacher preparation program, explain the procedures for completing evaluation forms and offer details on course content. Cooperating teachers may also receive an evaluation schedule and the requirements for conducting observations and conferences (Giebelhaus \& Bowman, 2002; Ramanathan \& Wilkins-Canter, 1997).

Mentor training.

Mentor training and programs sponsored by a school system can prepare cooperating teachers. Although these programs are intended to prepare experienced teachers to assist new or novice teachers entering the teaching profession, the strategies associated with mentoring can be used with student teachers. This training presents veteran teachers techniques on helping new teachers develop competence in areas such as classroom management skills, instructional planning and student engagement. Training may offer information on understanding adult learners, using goal-setting strategies, and enhancing communication skills (Evertson \& Smithey, 2000).

Mentoring programs can incorporate information on the roles, relationships and process of mentoring. Training may offer specifics on observation skills, clinical supervision approaches, giving feedback and providing reflective comments. Other topics may include identifying teacher needs, formative assessment techniques, and providing time for reflecting on practice (Diaz-Maggioli, 2004; Moir, 2005). 


\section{Supervision training.}

The research on cooperating teachers tends to focus on training programs, designated courses, and the knowledge needed for this role (Clarke, 2001: Koerner, 1992). Korinek (1989) concluded that cooperating teachers prefer training that focuses on supervisory skills, observations skills, and problem solving. Another study concluded that training should explain the purpose of field experiences, the roles and responsibilities of cooperating teacher, and supervisory skills (Ramanathan \&Wilkins-Canter, 1997).

Supervision training sponsored by a college or university helps cooperating teachers develop an understanding of the clinical supervision model (Kent, 2001; Wilkens-Canter, 1997). Cooperating teachers trained with the clinical supervision model report that it helped them promote student teacher self-reflection and provided support from the university and from cooperating teachers in other schools (Kent, 2001).

Wilkins-Canter (1997) concludes that cooperating teachers need to participate in a supervision course because it assists them in providing written feedback, creating opportunities for reflection, using observational skills, having conferences and collecting objective data. Without this training, they may fail to provide adequate supervisory student teacher feedback. Activities in supervision training include learning the goals and expectations of the teacher education program and the roles and responsibilities of the student teacher, cooperating teacher and university supervisor (Sudzina, Giebelhaus, \& Coolican, 1997). It can also support and enhance the communication between the university, school division, and cooperating teacher. This training strengthens a person's ability to manage student teachers' decisions and analyze their instructional and curricula choices (Dever, Hager, and Klein, 2003; McIntyre \& Killian, 1987). 
Universities offer supervision training for graduate credit hours (Dever, Hager, and Klein, 2003; Gareis, 2005; McIntyre \& Killian, 1987). This preparation may extend over a two-month period (Dever, Hager, and Klein, 2003) or be offered as a summer course with follow-up sessions through the school year (Gareis, 2005).

At some universities or colleges, cooperating teachers who complete this supervision course are designated as "clinical faculty." They receive the benefits of adjunct faculty status, a higher honorarium than non-trained cooperating teachers and chances to network with faculty and teachers from other school districts (Gareis, 2005).

Most of the studies on supervisory training conclude that teachers with this training provide better experiences for student teachers than non-trained cooperating teachers. For example, McIntyre and Killian (1987) found that trained cooperating teachers had more interactions and spent more time with the student teachers on planning, classroom routines, and discussing student teacher performance.

Giebelhaus and Bowman (2002) found that cooperating teachers trained using the Praxis III/Pathwise framework provided better planning, classroom instruction and reflection on practice than their untrained counterparts. Clarke (2001) found that untrained cooperating teachers are less likely to fail a student teacher. This researcher suggested that cooperating teachers with training are more likely to discriminate between excellent and poor student teachers (Clarke, 2001).

Preparing cooperating teachers should be an important component in teacher education. Noted earlier, cooperating teacher preparation improves feedback, understanding student teaching competencies, and assessing weaknesses and strengths. 
This preparation is also needed to help cooperating teacher manage the challenges that can occur.

\section{Cooperating teacher challenges}

Being a cooperating teacher may also present challenges and difficulties. The most common problem results from poor communication with the student teacher. Disputes with student teachers may stem from their poor work ethic or their lack of time or interest for reflecting, interacting and planning. Other problems arise from differences in personality, philosophy, and cultural misunderstandings. Cooperating teachers and student teachers may have disparities that center on evaluating student learning, discipline procedures, classroom climate and curriculum objectives (Ediger, 1994).

Cooperating teachers have challenges with the student teachers' university or college and with their supervision skills. Problems with colleges and universities may be attributed to the lack of clear communication concerning student teacher course requirements and student teaching guidelines. Other difficulties may lie in not knowing and understanding the college's or university's role in evaluation and not receiving supervision help from college or university supervisors. Cooperating teachers encounter problems in not knowing how to provide effective feedback, using appropriate interpersonal skills, and discerning how to honestly approach problematic situations. Some fear that offering corrective feedback could disrupt the student teaching experience (Kahn, 2001; Koerner, 1992; Koskela \& Ganser, 1995; Sudzina, Giebelhaus, \& Coolican, 1997).

Koerner (1992) concluded that being a cooperating teacher presents the challenges of interrupting instruction, displacing the teacher's central position, and 
disrupting classroom routines. Instruction is interrupted and classroom routines are disrupted because of the cooperating teacher's time and energy is involved in helping the student teacher learn classroom management and teaching techniques. Cooperating teachers felt their students' instruction was at risk due to the student teachers' inexperience and different style in handling classroom situations. They also felt displaced from their key position in the classroom due to the student teachers' influence and relationship with their students.

Cooperating teacher benefits

Challenges are part of the nature of being a cooperating teacher. However, the differences between cooperating teachers and student teachers can lead to learning for both parties. This is based on the assumption that their differences are related to sound learning philosophies and psychologies (Ediger, 1994).

Although Koerner (1992) noted many difficulties of this role, his results verified that this role helps an individual's professional growth because it causes them to reflect on themselves and on the teaching profession. Kosela and Ganser (1995) reported that cooperating teachers are challenged by their role as supervisors and the role of the university in preparing student teachers. However, cooperating teachers felt that this role was a positive professional experience.

Cooperating teachers benefit from supervising student teachers. This role offers the personal and professional benefits of increasing reflection skills, witnessing professional growth and improved classroom practices. Collaboration and acquiring new techniques are other benefits (Ganser, 1996; Kosela \& Ganser, 1995; Landt, 2002; Tatel, 1994). 
For cooperating teachers' this role increases an individual's personal growth by boosting their enthusiasm towards children and teaching, and it helps to affirm teaching skills and abilities. Teacher rejuvenation is also fostered and their experiences are validated through the giving and receiving of ideas, information and expertise (Koskela \& Ganser, 1995).

Cooperating teaching increases an individual's reflective abilities and improves classroom practices due to student teacher observations and interactions. This causes cooperating teachers to discover new things about learning and teaching, and assists them in making thoughtful changes in classroom practice. Reflection enables a person to examine her or his professional life and contribution. This role provides an avenue for examining how career knowledge has been acquired and it increases an awareness of instructional and classroom management techniques (Koerner, 1992; Koskela and Ganser, 1995; Ganser, 1996; Landt, 2002; Tatel, 1994).

Supervising student teachers helps cooperating teachers learn new applications of old ideas that may include team teaching, cooperative learning, and test construction. They also acquire new strategies and techniques for motivating students and new pedagogical methods. Student teachers help cooperating teachers learn new curriculum materials and assist them with the learning and using the latest computers and technology. Cooperating teachers' learning also occurs through observing their pupils. Seeing students' enthusiasm and engagement with student teachers' strategies and approaches can stimulate change within cooperating teachers (Landt, 2002; Tatel 1994). Being a cooperating teacher can be a personally rewarding experience because it provides a chance to witness the professional development and growth of another person. 
Cooperating teachers watch their student teachers develop and gain confidence in using instructional strategies, classroom management techniques, and in planning activities. They see their student teachers move from dependent to more autonomous behaviors (Ganser, 1997; Koskela and Ganser, 1995; Ganser, 1997; Ganser and Wham, 1998; Landt, 2002).

Collaboration is another benefit this role provides because it reduces teacher isolation and gives a person a chance to discuss and share thoughts. Through the collaborative efforts of the cooperating and student teacher, both parties acquire new ideas and techniques. Explaining your craft to another person is one way of exhibiting knowledge because it helps you to scrutinize your practice and assess the teaching components valuable for student learning (Ganser, 1996; Ganser, 1997; Koskela and Ganser, 1995; Ganser, 1997; Ganser and Wham, 1998; Landt, 2002).

Supervising student teachers provides many benefits for cooperating teachers. Cooperating teachers experience increased enthusiasm towards student learning and reflective abilities. They learn new instructional applications and gain many opportunities to collaborate on teaching ideas. This role also offers challenges which can provide chances for professional growth.

\section{Professional Development}

The tidal wave of school reform efforts has created changes in teaching and school organizations. Today's students are expected to achieve at much higher levels than previous generations of students. Professional development is critical for moving us from the rhetoric of high standards to permeate practice (Ball \& Cohen, 1999). 
Professional development can be defined broadly or as it relates to a process or activities. Using a broad definition, professional development is "any experience that enlarges a teacher's skills, knowledge, appreciation, and understanding of his or her work" (Glickman, Gordon, \& Ross-Gordon, 2001, p. 360).

Darling-Hammond and McLaughlin (1995) define professional development as "providing occasions for teachers to reflect critically on their practice and to fashion new knowledge and beliefs about content, pedagogy, and learners" (p. 597).

Elmore (2002) states that:

In practice professional development covers a vast array of specific activities, everything from highly targeted work with teachers around specific curricula and teaching practices through short, "hit-and-run" workshops designed to familiarize teachers and administrators with new ides or new rules and requirement, to off-site courses and workshops designed to provide content and academic credit for teachers and administrators. (p. 6)

Landt (2002) states that professional development is "an ongoing process where participants are actively involved in investigating ideas and practices that fit the conditions of their specific situations while also expanding their comprehension of the larger context of school and society" (p. 9).

Using a combination of the above definitions, professional development is an ongoing process that continuously improves educator knowledge through activities that cause critical reflection.

As the above examples reveal, while there are similarities, no commonly agreed upon definition of professional development. Having a definition of this term will guide 
our thinking cooperating teaching is a professional growth experience. To help address this concern, the professional development standards of the NSDC have been selected to frame our understanding of a cooperating teacher.

\section{Professional Development Standards}

Professional development quality has been a major element in policy makers' efforts to improve schools. The United States federal government enacted the No Child Left Behind (NCLB) legislation in 2002 in an effort to make schools more accountable for student achievement. Under this act, high quality professional development activities:

- Increase the academic knowledge of teachers

- Integrate school and district wide educational improvement plans

- Align with academic standards and assessments

- Assist teachers in gaining instructional strategies, classroom management skills, and the knowledge for teaching limited English proficient skills.

- Provide technology training for teachers and principals.

- Provide instruction on how to use data to inform instruction

- Assist school personnel on how to work effectively with parents.

- Can have programs for paraprofessionals

- Can form partnerships with institutions of higher education to establish school-based teacher training teacher programs.

National education organizations, teacher organizations, research groups, and governmental bodies have published lists and standards that address the characteristics of quality or effective professional development (Guskey 2003a, 2003b). Standards assist 
educators in defining what students need to learn and do. They also provide guidance on how educators can support student learning at high levels (Hirsch, 2001).

Noted earlier, there is not a consistent definition of professional development. Guskey's (2003a, 2003b) analysis of the professional development standards supports this view. He explored the professional development standards of 13 prominent educational organizations. His analysis revealed that there is limited agreement on the criteria for effective professional development due to the different ways the lists are generated. Groups developed their criteria for different purposes and audiences, while others formed their criteria from self-report data and/or through a consensus of opinions.

The majority of the professional development standards in Guskey's review emphasized time, resources, collegiality, collaborative exchange, and activities aligned with school reform initiatives. Other characteristics included activities that are school or site-based, build leadership capacity, and are based on the identified needs of teachers (Guskey 2003a, 2003b).

\section{National Staff Development Council (NSDC) Standards}

The NSDC standards are broad, comprehensive and represent an ideal view of professional development based on expert opinion (Guskey, 2002). They describe a complete professional development system that involves the consistent efforts of all members in the organization. These standards start with the underlying assumption that school is the center for change (Roy, 2004a).

The NSDC upholds the belief that standards should provide the direction for developing professional development experiences. The standards of this organization are guided by high expectations for student learning, increasing teacher knowledge in order 
to ensure student success, and having staff development that is focused on meeting these goals (NSDC, 2001). For these reasons, the NSDC standards were selected to frame this study on how cooperating teachers perceive this experience as a professional development activity. Each NSDC standard provides a rationale and annotated bibliography that gives insights and details on their meaning.

The 12 NSDC standards are grouped into the categories of context, process and content standards. The context and content categories each have three standards, and the process category has six standards. These categories accompany each other to build the plan, design and implementation of professional development that will impact student learning. Removing any category diminishes the intended goals of the professional development (Roy, 2004b).

Table 2

National Staff Development Council (NSDC) Professional Development Standards

\begin{tabular}{lll}
\hline \multicolumn{1}{c}{ Context } & \multicolumn{1}{c}{ Process } & Content \\
\hline- Learning & $\bullet$ Data driven & $\bullet$ Equity \\
communities & $\bullet$ Design & $\bullet$ Quality Teaching \\
- Leadership & - Learning & Family Involvement \\
& - Evaluation & \\
& - Research Based & \\
& - Collaboration & \\
\hline
\end{tabular}

\section{Context of professional development.}

Context standards address where the learning occurs -- the who, when, where, and why of the professional development. This involves knowing the traits of the educators, organization, and the environment involved in the professional development activity (Guskey \& Sparks, 2002; Hirsch, 2001).

The NSDC (2001) context standards are divided into three focus areas: 
- Learning communities: They use ongoing teams of various sizes that are involved in problem solving, joint planning, and making continuous improvements. The teams help determine learning needs that are aligned with school and district goals.

- Leadership: Leaders' efforts and support are needed to make improvements in teacher learning. Leaders should continuously guide instruction, have policies and structures to support ongoing professional learning, and distribute their leadership responsibilities among teachers.

- Resources: Resources support adult learning and collaboration. The majority of the professional learning should take place within the school day. However, outside sources, such as workshops or trainers, can be used to increase teacher knowledge. Stipends and other funds can be used to support teachers in lead positions.

Process standards of professional development.

Process standards relate to how the learning activities are planned, organized, carried out and followed up. They address how adults will acquire the knowledge, skills, and dispositions to affect student learning. These standards also involve using student data to determine goals, using collegiality to support change and having a variety of models to develop knowledge. (Guskey \& Sparks, 2002; Roy, 2004b; Hirsch, 2001).

The NSDC (2001) process standards are divided into 6 focus areas:

- Data-driven: The purpose of staff development relies on student data, standardized tests, district tests, student work, and teacher made tests. This 
information determines learning priorities, monitors student progress, and is needed for sustaining continuous improvements.

- Evaluation: Multiple data points should be used to guide and direct the impact of improvements. Evaluation begins with clarifying outcomes, selecting the appropriate forms of adult learning, and deciding how the outcomes will be judged. It also focuses on the acquisition of teaching skills and if the teachers' changed behavior has affected student learning.

- Design: A variety and a combination of strategies should be used for teacher learning. Strategies include, but are not limited to, curriculum development, study groups, collaborative lesson design, coaching, and action research.

- Learning: This involves moving an individual from basic to deeper comprehension levels and provides opportunities for interacting with ideas or procedures. Deeper levels of understanding are facilitated through reflection, dialogue and from the feedback on observed lessons.

- Collaboration: This provides educators with the knowledge and skills needed for collectively meeting goals and objectives. This standard implies that learning can occur in a variety of group settings. Groups provide a social interaction that deepens learning and promotes problem solving.

- Research-based: This standard promotes activities that prepare educators to apply research to decision making. Educators should become informed consumers when selecting research for professional learning efforts. 
Content standards of professional development.

Content standards involve educators gaining the knowledge and skills to ensure student learning. This is the foundation of all professional development efforts. They provide a deeper understanding of the academic disciplines and give educators current knowledge of pedagogy (Guskey \& Sparks, 2002; Hirsch, 2001).

The NSDC (2001) content standards are divided into 3 areas:

- Equity: This standard involves promoting activities that involve having an appreciation and understanding of all students and establishing a safe and orderly learning atmosphere. Plans may include how to differentiate instruction to meet the various ability groups in a classroom.

- Quality teaching: Staff development that uses this standard promote teacher learning in using research-based instructional strategies and content knowledge. Activities also include how to appropriately use classroom assessments.

- Family involvement: This standard includes learning how to engage the family and community in the school. Activities entail gaining information on family cultural backgrounds and hearing the best approaches for using technology as a tool for communication.

The NSDC standards (2001) provide a comprehensive framework for defining our view of professional development. They are based on research and were developed by 25 educators who represented 15 educational organizations and the members of the NSDC. These standards remind us that successful professional development is dependent on the 
simultaneous use of context, process, and content. Research has also identified features that should be incorporated in professional development activities.

\section{Professional development features}

Based on the self-reported teacher data of over 1,000 science and math teachers, Garet, Porter, Desimone, Birman, and Yoon, (2001) identified characteristics of professional development features that raise teacher learning categorized as structural and core. These features are listed in Table 3. The data were collected through an evaluation of the Eisenhower Professional Development program and was the first large studies to compare the effects of the different traits of professional development. Structural features provide the context of the professional development experience and are classified as form, duration, and participation. The core features of professional development emphasize teacher learning are classified as content focus, active learning, and coherence (Birman, Desimone, Porter \& Garet, 2000; Garet, Porter, Desimone, et. al, 2001).

Table 3.

Features of professional development

\begin{tabular}{ll}
\hline Structural & Core \\
\hline$\bullet$ Form & $\bullet$ Content focus \\
- Duration & $\bullet$ Active learning \\
- Collective participation & $\bullet$ Coherence \\
\hline
\end{tabular}

The form of professional development activities have undergone a paradigm shift from traditional formats to reform patterns. This shift represents a change in how professional learning is presented and processed. Traditional formats have been characterized for their fragmented activities, being disconnected from the classroom, and 
being focused only on school district goals. This format tends to use an expert presenter to transmit knowledge and inform. The activities of this format are critized by educators for failing to provide adequate time and content so teachers can make meaningful changes in classroom practices (Sparks \& Hirsch, 1997; Speck \& Knipe, 2001). In contrast, reform patterns of professional development activate teachers' knowledge, affect student learning and treat teachers as transmitters of their own teaching and knowledge. Professional developers are used as consultants and for planning and facilitating workshops. Ample opportunities are provided for teachers to learn the new strategies and integrate them into practice. Reform patterns are intended to develop school and teacher capacity and incorporate peer review methods and collaborative inquiry. Activities take place during the school day and involve teachers using study groups, mentoring or coaching. Although workshops, courses, institutes, and conferences are considered traditional professional formats, these formats can incorporate the reform pattern characteristics that were described. (Birman, Desimone, Porter et. al, 2000; Darling-Hammond \& McLaughlin, 1995; Garet, Porter, Desimone, et. al, 2001; Landt, 2002).

Teacher learning is affected by the duration of the professional development activities. One-day workshops generally provide limited opportunities to learn and acquire new strategies. In contrast, longer activities can provide chances for in-depth conversations and time for teachers to obtain feedback on their new practices. Professional development activities should have continuous experiences and use support from external and or internal resources. The duration or length of these activities should be thoroughly planned, include classroom release time, and involve the participants in 
playing an active role in selecting the goals and activities (Darling-Hammond \& McLaughlin, 1995; Hawley \& Valli, 1999; Kent, 2004; Sparks \& Loucks-Horsley, 1989; Yost, 2002).

Collective participation, the last structural feature, uses designated teacher groups who generally work in the same building. Group meetings can discuss common concerns, identify potential solutions, and the concepts that are provided in a professional development workshop. When skillfully executed, this leads to a clarification of learning and shared knowledge. Collective participation offers the potential for teachers to share materials and help each other sustain a particular change in practice (Birman, Desimone, Porter \& Garet, 2000; Darling-Hammond \& McLaughlin, 1995; Garet, Porter, Desimone, et. al, 2001; Hawley \& Valli, 1999; Kent, 2004; Sparks \& Loucks-Horsley, 1989).

Content focus, active learning, and coherence are the core features of a professional development experience. Activities with a content focus may emphasize learning in a subject area and knowledge and/or pedagogical skills. They can also involve teaching educators how to help students learn subject matter and use curriculum materials (Garet, Porter, Desimone, et. al, 2001).

Active learning utilizes meaningful teacher discussions on student learning, planning, practice, and curriculum materials. Other dimensions of this involve observing, being observed, reviewing student work, presenting, and writing. Watching a videotape is a viable option for observing and being observed. Active learning connects to and engages a person's beliefs and experience. This causes them to transform formal knowledge into practical knowledge (Brown, 2002; Hawley \& Valli, 1999). 
Coherence is linking professional development goals, activities, and teacher involvement. The goals and activities of coherent professional development relate to:

- student learning and performance

- national, state, or local standards

- national, state, or local assessments

Teacher involvement is needed to identify student learning needs and opportunities. This involvement uses teacher dialogue to share concerns and present possible solutions. Professional development is most effective when it is derived from the teacher's work and is connected to aspects of school change (Brown, 2002; DarlingHammond \& McLaughlin, 1995; Hawley \& Valli, 1999; Kelleher, 2003; Kent, 2004; Garet, Porter, et al. 2001).

Collectively, the core features emphasize subject matter, pedagogy, dialogue about student learning and linking goals and activities. The structural and core features of professional development represent what characteristics raise teacher learning. Teacher learning raises student achievement. The features of good professional development incorporate building teacher capacity and emphasize longer activities that use collaboration. This collaboration can emphasize subject area knowledge, discuss the many dimensions related to student learning, and have activities that are related to student learning, assessments and standards. Cooperating teaching is equivalent to a professional development activity. Cooperating teachers are involved in in-depth collaborative activities with student teachers that are related to student learning, content knowledge, and curriculum materials. Cooperating teaching may well be considered an alternative format of professional development. 


\section{Alternative professional development formats}

Education is in an era that is traveling away from "expert" presenters and "oneshot" workshops. Due to this evolving pattern, various formats or alternatives to training models may be considered as professional development. Noted earlier, traditional form of professional development use the expertise of individual to disseminate information at a scheduled time (Speck \& Knipe, 2001). Alternative formats or activities engage teachers in genuine questions or problems over an extended time that relate to student learning, content, and instruction. They also provide access to a broader professional community of learners (Little, 1993).

Currently, cooperating teaching is generally unrecognized as a professional development activity (Ganser \& Wham, 1998). However, as previously stated cooperating teaching is equivalent to professional development in part because it is linked to authentic concerns related to student instruction and learning. This section will describe other accepted alternative formats or activities that are generally accepted as professional development. They include partnerships, teachers as writers, mentoring programs, collegial support groups, learning communities, internal networks, external networks, individually planned professional development, skill development programs, and teacher leadership (Glickman, Gordon \& Ross-Gordon, 2001).

Schools and universities and schools and businesses are examples of partnerships. In these arrangements, both groups are considered equal, make contributions, and receive benefits. University and public school partnerships work toward creating optimal experiences for student teachers by connecting academic learning and practical experiences. The benefits of this arrangement include helping teachers to become more 
responsive to professional development and helping faculty members stay current with teaching realities and trends (Dever, Hager, \& Klein, 2003). The school and business partnership focuses on improving education and the community through a mutual agreement on goals. Schools and teachers benefit from the additional funds which can provide professional development opportunities, professional expertise for hands-on projects and up-to-date equipment. For business, this partnership helps them develop future workers and gives them the satisfaction of having an effect on the educational quality (Warden, 1986).

Teachers can experience professional growth through writing. Writing is a tool that stimulates reflection on teaching and students. Writing formats can range from simple formats (e.g., personal journal writing) to more complicated forms (e.g., reaction papers and articles for publication) (Glickman, Gordon, \& Ross-Gordon, 2001). Journal writing, for example, helps adult learners to have thoughts that are more visible and concrete. It enhances adult memory and provides a context for an individual's future growth and improvement (Kerka, 1996).

In mentoring programs, experienced teachers are assigned to novice teachers for individualized support and assistance. Many mentoring programs use a sequenced process that consists of first selecting the mentor using predetermined criteria. The optimal mentor is people-oriented, possesses instructional expertise, is flexible, and has the time and willingness to nurture another person. Then, the mentor receives training and is matched to a protégé. In the next phase, the mentor and protégé establish goals and expectations for this experience. Successful mentoring programs benefit both individuals by increasing their career aspirations, creativity and work ability (Janas, 1996). 
Collegial support groups, learning communities and internal networks are similar alternative professional development formats. They all utilize teachers within a school who collectively dialogue and collaborate on educational issues. These discussions lead to teacher empowerment, ownership and shared responsibility. Collaboration among several teachers with in the same building is an effective element of professional development (Murphy, 2005). In collegial support groups, teachers work on solving problems or implementing instructional innovations (Glickman, Gordon \& Ross-Gordon, 2001). Teachers in learning communities share common experiences, problems, and ideas. This collaboration may also involve planning professional development activities and sharing resources (Murphy, 2005). Professional networks (internal and external) connect teachers on common concerns, goals, and strategies (Loucks-Horsley, Hewson, Love \& Stiles, 1998). Internal networks use teacher dialogue that primarily concentrates on making structural changes in school. Discussions can happen in grade-level, department, or interdisciplinary team meetings. In these meetings, teachers may review research, explore new teaching ideas, and discuss their experiences with new or existing instructional strategies (Morris, Chrispeels, \& Burke 2003). In contrast, external networks use teachers from different schools and regions to share information and concerns. Data are exchanged through computer links, newsletters, and other types of media (Glickman, Gordon, \& Ross-Gordon, 2001). This collaboration is primarily voluntary and uses reciprocal interaction. Successful external networks provide a supportive environment that enhances teachers' pedagogical knowledge and skills and expands their subject matter knowledge (Morris, Chrispeels, \& Burke, 2003). 
Teachers who have individually planned professional development formulate their own learning goals that are aligned with school and/or district need. This also involves creating a structured plan that includes self-reflection and a method for evaluating the plan's success. This type of professional development is based on the assumption that adults are the best judges of their learning needs and professional growth is stimulated by real life problems and tasks. Learning based on realistic concerns will increase an individual's commitment to their growth and development (Sparks \& Loucks-Horsley, 1989; Speck \& Knipe, 2001).

Skill development programs present workshops over a period of time and enlist the use of a "coach" or presenter to help teachers transfer new skills into their existing practice (Glickman, Ross, \& Ross-Gordon, 2001). These programs are based on clear learner outcomes and the assumption that there are instructional behaviors and techniques worth replicating. The "coach" models how to implement the skill. The teacher applies the new skill with her or his students and the coach provides feedback on the teacher performance (Gall \& Vojtek, 1994; Sparks \& Loucks-Horsley, 1989).

Teacher leadership is another alternative professional development format. A teacher leader influences others, engages colleagues, helps teachers work collaboratively, and promotes change. This person models positive attitudes and enthusiasm, and devotes her or his time towards enhancing the school climate (Murphy, 2005). This adult-centered activity occurs primarily outside of the classroom. Teacher leaders are classified by an assortment of names, roles, and responsibilities which include lead teacher, grade-level chair, hospitality committee chair, and building liaison to a school division committee. The activities associated with teacher leaders entail workshop presenter, cooperating 
teacher, mentor, expert coach, and curriculum developer (Glickman, Gordon \& RossGordon, 2001; Murphy, 2005). Teacher leadership development programs should begin with the belief that teacher growth runs along a continuum and learning is a continuous process. Growth opportunities should have challenges to move individuals beyond their comfort zone. These opportunities enable individuals to learn and apply their new knowledge (Murphy, 2005).

Alternative form of professional development help school districts and organizations manage the challenge of providing time for teacher professional development. Schools can rethink schedules by arranging teachers to have block time or common planning periods, extending the school day or year, and altering staff utilization patterns. Professional development opportunities can be integrated in a school's routine. Departmental meetings can serve as "mini-seminars." Serving on a school instructional committee can enhance teacher practice because these experiences usually involve examining materials, planning curricula and discussing assessments. Giving teachers the opportunity to plan master schedules or make student placements also helps them to reflect on school norms, goals and basic assumptions of the school climate (Abdal-Haqq, 1996; Darling-Hammond \& McLaughlin, 1995). Cooperating teaching can also be considered an alternative form of professional development. This role is integrated into a schools routine and provides opportunities to discuss curriculum instruction and assessment. All professional development formats need to be evaluated to determine their effectiveness. 


\section{Evaluating professional development}

Measuring the effectiveness of a professional development activity is dependent on evaluation procedures. Evaluation is the "systematic investigation of worth" (Guskey, 2000 , p. 41). It incorporates analyzing pertinent data that is collected through a thoughtful and intentional process to appraise the worth of a program or activity (Guskey, 2000).

In education, the purpose of evaluating professional development is to make improvements and judgments based on clear objectives and goals related to student outcomes. It should begin when program goals are planned and evaluation continues through out all phases of the program implementation. Good evaluation is informed by multiple sources including quantitative and qualitative data. The views and opinions of all program components including school leaders, parents, teacher and students should be incorporated into the evaluation efforts (Guskey \& Sparks, 1991).

Evaluation reveals many aspects about a program. It can indicate strengths and weakness that will help improve future programs. Evaluation provides information to help determine if a project or program should be continued or discontinued. Evaluating programs also helps leaders to justify a program's existence (Kirkpatrick, 1996).

Guskey $(2000,2002 \mathrm{a})$ proposes a model of evaluating professional development that uses five levels that are arranged from simple to complex. At the first level of evaluation, the participants' initial satisfaction of the workshop is measured usually through a questionnaire or survey form. The participants are asked questions that measure their happiness quotient. Questions ask about the quality of the workshop facility, food, materials, and presenter. Moving to the higher levels of professional evaluation is dependent on positive experiences at this level. 
Level two measures the new knowledge and skills gained by the participants. This can be assessed through paper-and-pencil instruments, demonstrations, and written or oral reflections. Assessing participants learning is dependent on identifying learning goals prior to the professional development experience. Evaluators should be aware of the possible positive or negative unintended learning outcomes that could be gained (Guskey 2000, 2002a).

Level three assess the organizational support and change of the professional development effort. Information is gathered from structured interviews, questionnaires, focus groups and district or school records. At level four, participant use of new knowledge and skill, information is gathered from direct observations, participant oral and written reflection, structured interviews, and video. Before evaluators have measured how knowledge has been applied sufficient time needs to pass (Guskey 2000, 2002a).

The last level measures how the professional development has impacted student learning outcomes. Collecting knowledge on student impact can be obtained through structured interviews of student, teachers, and parents, student records and student scores on a standardized measure (Guskey 2000, 2002a).

Kirkpatrick (1996) has a model for evaluating training that is similar to the Guskey level's. However, this plan uses a four level evaluation plan emphasizes supervisory and management training. This plan ịs applicable for educational use and has the levels: reaction, learning, behavior, and results. Training programs include any course or program that is intended to increase knowledge and skills. The evaluation levels of Guskey $(2000,2002 \mathrm{a})$ and Kirkpatrick are listed in Table 4. 
Table 4

Professional development evaluation

\begin{tabular}{ll}
\hline \multicolumn{1}{c}{ Guskey $(2000,2002 \mathrm{a})$} & \multicolumn{1}{c}{ Kirkpatrick (1996) } \\
\hline Level one--participant reaction & Level one--reaction \\
Level two--participant learning & Level two--learning \\
Level three--organizational support and change & Level three--behavior \\
Level four--participant new knowledge and & Level four--results \\
skill & \\
Level five--student learning outcomes & \\
\hline
\end{tabular}

At level one in Kirpatrick's framework, reaction, the satisfaction of the participants, is measured. It tells how future sessions can be improved, how the trainers can do a better job, and provides data for leaders who are concerned about the program. Forms that measure participant satisfaction should use a clear and simple design that encourages written comments and honest feedback (Kirkpatrick, 1996).

At the next level, learning, the participants' improvement or increase change in attitudes, knowledge or skills, are analyzed. Guidelines for measuring this include having participants complete a paper pencil test before and after the program and when practical, the use of a control group (Kirkpatrick, 1996).

Behavior is the third level and measures if the participants have changed their behavior as a result of the attending the workshop. Changed behavior occurs when an individual has the desire, knows the how and what to dos, has the proper work climate, and has been rewarded for changing. All of these conditions must be met before change can occur. Methods for evaluating this include by comparing pre and post data and using survey and/or interview data (Kirkpatrick, 1996).

Results, the final level, is "the final results that occurred because the participants attended the program"' (Kirkpatrick, 1996, p. 25). The objective of the training is based 
on the results. The training begins by determining what behavior, attitude, or knowledge needs to be changed. Evaluation at this level is dependent on time (Kirkpatrick, 1996).

Kirkpatrick (1996) states that sequencing training program evaluation progresses along these levels. Reaction is the easiest to measure while the results level is more difficult and complex. Planning a professional development experience uses these levels in reverse. The results of the program are established and participant reaction is measure last.

Guskey's (2000,2002a) and Kirpatrick's (1996) model of evaluating professional development have similarities. The levels in both models range from simple and complex and the levels suggest a sequence for evaluating professional development. The initial levels of each model measure participant reaction to the professional development activities while the upper levels measure any change or increase in participant knowledge. When planning a professional development activity, the levels of both models are used in reverse.

Cooperating Teaching as Professional Development According to Ganser (1997), cooperating teaching is better than traditional forms of professional development such as courses or workshops because it provides a hands-on experience that includes verbalizing, reflecting, and interacting with another adult (Ganser, 1997). Research on this experience indicates that it affects a person's professional development. Although these studies are limited in number, they all suggest that cooperating teachers experience professional growth as a result of supervising student teachers. 
The studies listed in Table 5 have addressed cooperating teaching and professional development and indicate the areas that have been positively influenced.

Cooperating teaching has been viewed as professional development because it affects an individual's teaching practice, reflective abilities, and collegiality.

Table 5

Cooperating teacher research that addresses professional development

\begin{tabular}{|c|c|c|c|c|c|}
\hline Author(s) & $\begin{array}{l}\text { Methodology } \\
\text { Participants }\end{array}$ & $\begin{array}{l}\text { Research Question(s)/ } \\
\text { Research Purpose }\end{array}$ & 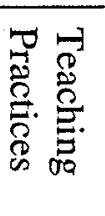 & 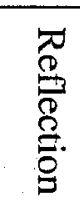 & 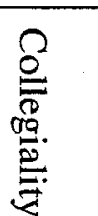 \\
\hline $\begin{array}{l}\text { Arnold } \\
2002\end{array}$ & $\begin{array}{l}\text { Qualitative } \\
\text { Content analysis } \\
5 \text { High school } \\
\text { cooperating } \\
\text { teachers }\end{array}$ & $\begin{array}{l}\text { To investigate the changes in perceptions } \\
\text { of cooperating teachers and if work of a } \\
\text { cooperating teacher impacted students' } \\
\text { perception of classroom life. }\end{array}$ & * & & \\
\hline $\begin{array}{l}\text { Ganser } \\
1997\end{array}$ & $\begin{array}{l}\text { Qualitative } \\
\text { Survey } \\
\text { Follow-up } \\
\text { interviews } \\
157 \mathrm{~K}-12 \\
\text { cooperating teacher } \\
\text { and mentors }\end{array}$ & $\begin{array}{l}\text { To investigate the impact of serving as } \\
\text { cooperating teacher and mentor on their } \\
\text { own professional development }\end{array}$ & $\therefore$ & & $*$ \\
\hline $\begin{array}{l}\text { Gibbs } \\
\text { Montoya } \\
1994\end{array}$ & $\begin{array}{l}\text { Qualitative } \\
\text { Survey } \\
225 \text { elementary } \\
\text { cooperating } \\
\text { teachers }\end{array}$ & $\begin{array}{l}\text { Do cooperating teachers perceive student } \\
\text { teachers to be a positive addition to the } \\
\text { classroom? } \\
\text { Do student teachers play a role in the } \\
\text { professional development of cooperating } \\
\text { teachers? }\end{array}$ & * & . & \\
\hline $\begin{array}{l}\text { Holm } \\
2004\end{array}$ & $\begin{array}{l}\text { Qualitative } \\
\text { Survey and } \\
\text { interviews } \\
46 \text { elementary } \\
\text { cooperating } \\
\text { teachers }\end{array}$ & $\begin{array}{l}\text { To what extent is the supervision of } \\
\text { student teachers seen as a professional } \\
\text { growth experience by cooperating } \\
\text { teacher? Does the experience change the } \\
\text { professional practice of cooperating } \\
\text { teachers? If so, in what ways? What do } \\
\text { teachers see as the benefits of supervising } \\
\text { a student teacher? }\end{array}$ & & $*$ & * \\
\hline
\end{tabular}




\begin{tabular}{|c|c|c|c|c|c|}
\hline $\begin{array}{l}\text { Kiraz } \\
2004\end{array}$ & $\begin{array}{l}\text { Qualitative } \\
26 \text { elementary } \\
\text { student teachers; } \\
11 \text { K-6 supervising } \\
\text { teachers; } 3 \\
\text { university } \\
\text { coordinators }\end{array}$ & $\begin{array}{l}\text { In what areas does the interaction between } \\
\text { student teachers and their supervising } \\
\text { teachers contribute to supervising } \\
\text { teachers' professional growth? } \\
\text { In what ways do student teachers } \\
\text { contribute to supervising teachers' } \\
\text { professional growth? }\end{array}$ & $*$ & $*$ & $*$ \\
\hline $\begin{array}{l}\text { Koerner } \\
1992\end{array}$ & $\begin{array}{l}\text { Case study } \\
\text { Qualitative } \\
8 \text { elementary } \\
\text { cooperating } \\
\text { teachers }\end{array}$ & $\begin{array}{l}\text { What are the consequences of having an } \\
\text { adult student in an elementary school } \\
\text { classroom? How do classroom teachers } \\
\text { construe the role of cooperating teacher? } \\
\text { How does this role affect their } \\
\text { professional development? }\end{array}$ & & $*$ & \\
\hline $\begin{array}{l}\text { Koskela } \\
\text { Ganser } \\
1995\end{array}$ & $\begin{array}{l}\text { Qualitative Survey } \\
302 \\
\text { K-12 cooperating } \\
\text { teachers }\end{array}$ & $\begin{array}{l}\text { What might cooperating teachers learn } \\
\text { about themselves when working with } \\
\text { student teachers? } \\
\text { What is the impact of serving as a } \\
\text { cooperating teacher on one's personal } \\
\text { career path? } \\
\text { What is satisfying or problematic about } \\
\text { the role of the cooperating teacher? } \\
\text { What contributions may the cooperating } \\
\text { teacher make to their profession? }\end{array}$ & * & & \\
\hline $\begin{array}{l}\text { Landt } \\
2002\end{array}$ & $\begin{array}{l}\text { Qualitative } \\
\text { Interview } \\
18 \text { secondary } \\
\text { cooperating } \\
\text { teachers }\end{array}$ & $\begin{array}{l}\text { Do 'cooperating teachers' practices change } \\
\text { as a result of working with a student } \\
\text { teacher? } \\
\text { Does the role of cooperating teacher } \\
\text { stimulate veteran teachers' reflection on } \\
\text { their teaching practices? } \\
\text { What are the processes that affect veteran } \\
\text { teachers' practices when they take on the } \\
\text { role of cooperating teacher? }\end{array}$ & & * & $\dot{*}$ \\
\hline
\end{tabular}




\begin{tabular}{|c|c|c|c|c|c|}
\hline Author(s) & $\begin{array}{l}\text { Methodology } \\
\text { Participants }\end{array}$ & $\begin{array}{l}\text { Research Question(s)/ } \\
\text { Research Purpose }\end{array}$ & 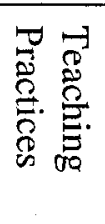 & 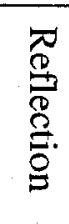 & 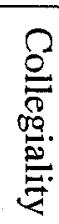 \\
\hline $\begin{array}{l}\text { Lemlech } \\
\text { Hertzog } \\
1999\end{array}$ & $\begin{array}{l}\text { Exploratory Case } \\
\text { study } \\
8 \text { master teachers } \\
3 \text { supervising } \\
\text { teachers } \\
4 \text { university } \\
\text { supervisors } \\
56 \text { elementary } \\
\text { student teachers }\end{array}$ & $\begin{array}{l}\text { Supervising two partner student teachers, } \\
\text { what did the master teachers learn about } \\
\text { professional relationships and their own } \\
\text { leadership role? }\end{array}$ & $*$ & * & \\
\hline $\begin{array}{l}\text { Tatel } \\
1994\end{array}$ & $\begin{array}{l}\text { Qualitative } \\
\text { Semi-structured } \\
\text { interview } \\
30 \text { secondary } \\
\text { cooperating } \\
\text { teachers } \\
\end{array}$ & $\begin{array}{l}\text { To identify changes that experienced } \\
\text { teachers make in their actual classroom } \\
\text { practice-changes that improve their } \\
\text { effectiveness-as a result of supervising a } \\
\text { student teacher. }\end{array}$ & $*$ & & \\
\hline
\end{tabular}

Cooperating teachers improve, change, and learn new teaching practices as a result of supervising student teachers. The changes range from minor to major modifications. Cooperating teachers learn new possibilities for familiar applications such as team teaching or cooperative learning. This experience heightens their awareness of innovative techniques (Arnold, 2002; Gibbs \& Montoya, 1994; Holm, 2004: Koskela \& Ganser, 1995; Landt, 2002).

Researchers conclude that changes in teaching practices are due to the cooperating teachers observations and the verbal interactions with student teachers. When cooperating teachers observe the implementation of a new technique and sees pupil enthusiasm and engagement, this creates change. Observing also helps cooperating teachers to discover new things about teaching and student learning. Cooperating teachers also learn new teaching methods because they want to be able to critique and discuss them with the student teacher. The verbal interactions occur during the student 
teacher/cooperating teacher conferences (Kiraz, 2004; Landt, 2002; Lemlech \& Hertzog, 1999).

Koerner (1992) reported that being a cooperating teacher causes an individual to reflect on self as practitioner and on the teaching profession. When reflecting as a practitioner, a person thinks about classroom organization, classroom management, instruction, and how knowledge was acquired through the years. Reflecting on the teaching profession has a person examine the causes and affects of his or her professional experiences.

The increase in cooperating teachers' reflective abilities is also attributed to student teacher observations and discussions. The student teacher observations cause them to reflect teaching concerns and problem solving approaches. These discussions help cooperating teachers to reflect on their practices as they explain issues about in and out of school concerns (Holm, 2004; Kiraz, 2004; Landt, 2002; Lemlech \& Hertzog, 1999).

Cooperating teaching has been viewed as a professional development experience because it enhances an individual's collegiality. Collegiality is having a relationship that has mutual exchange of perceptions and expertise (Kiraz, 2004). Cooperating teacher collegiality is increased due to the listening and giving of feedback during the student teacher conversations and interactions (Lemlech \& Hertzog, 1999). Working closely with a student teacher is viewed as a positive experience that lessens teacher isolation and improves your interpersonal and communication skills (Ganser, 1997; Holm, 2004; Landt, 2002). 
The studies in Table 5 conclude that cooperating teaching affects an individual's professional growth. However, they fail to provide a definition on how professional growth or development was measured. Noted earlier, studies suggested that this role provides professional growth due to changed practices and increased reflection. It is possible to change ineffective teaching practices to other ineffective practices. Research on adult learning reminds us that reflecting on thoughts and behaviors is necessary for learning and development (Hawley \& Valli, 1999). However, reflection does not necessarily produce a positive change. It may just simply clarify what a person has always believed about teaching and learning (Koskela \& Ganser, 1995).

This study intends to provide a firmer foundation of cooperating teaching as professional development by describing this role with more specific features and factors. It hopes to distinguish itself from other studies by viewing the role of a cooperating teacher through the lens of the best practices of professional development as defined by the NSDC. This study will potentially add a greater depth of our understanding of cooperating teaching as professional development because the results will indicate how serving as a cooperating teacher uses the categories and standards of the NSDC. These standards and categories of the NSDC were explained in a previous section.

The cooperating teachers in the majority of previous studies have either been elementary or secondary teachers. This research used a K-12 population allowed the experiences between the different groups to be compared. This study determined how factors such as number of student teachers supervised, years of teaching experience and cooperating teacher preparation affected cooperating teachers' perceptions on this role as 
a professional development experience. The research methodology, questions, and data analysis will be further explained in Chapter 3. 


\section{Chapter III: Methodology}

Cooperating teachers are responsible for assisting student teachers with their personal and social development within the school context (Boudreau, 1999). Effective professional development is linked to the teachers' classroom, relies on student data, is driven by results, causes teachers to become immersed in instructional strategies and subject matter, and is centered on curriculum (Sparks \& Hirsch, 2000). The purpose of this descriptive study was to determine the degree to which serving as a cooperating teacher is a professional development activity that aligned with the National Staff Development Council (NSDC) standards. The primary research question was:

Using the standards of the NSDC as a survey framework, how do cooperating teachers' perceive student teacher supervision as a professional development activity?

Research questions follow:

1. Does the role of cooperating teaching support the context standards needed for professional development?

2. Does the role of cooperating teaching support the process standards needed for professional development?

3. Does the role of cooperating teaching support the content standards needed for professional development?

4. To what degree do cooperating teachers at different grade levels (elementary, middle, and high) have different perceptions of student teacher supervision as a professional development activity? 
5. What is the relationship between cooperating teachers' experience levels (degree earned, years of full time teaching, and number of student teachers supervised) in their perceptions of student teacher supervision as a professional development activity?

6. What is the relationship between cooperating teachers with different preparation (no training, informal meeting, student teacher orientation, mentorship training, or clinical faculty training) in their perceptions of student teacher supervision as a professional development activity?

7. What demographic factors help predict how cooperating teachers perceive the supervision student teachers as a professional development activity? In this study, cooperating teachers in grades K-12 completed the researcher's modified version of the Standards Assessment Inventory (SAI) and was titled Cooperating Teacher and Professional Development. The modified version measured cooperating teachers' perceptions of this role as a professional development activity. The data for this survey instrument was collected over a three week period. It was analyzed using descriptive statistics, frequency counts, analysis of variance (ANOVA) and multiple regression analysis. Surveys are used in quantitative research to describe the attitudes, opinions or characteristics of population (Creswell, 2005). This chapter will provide further discussion on the participants, setting, instrument, instrument development, data collection, and data analysis.

\section{Participants and Setting}

The participants were elementary, middle, and high school cooperating teachers who were affiliated with a moderate-sized university in southeastern region of the United 
States. There were 287 participants who were general or special education cooperating teachers. The criterion for selection was supervising one or more student teachers in the past five years.

The cooperating teachers in this study represented a convenience sample due to their availability and close proximity to the researcher (Fraenkel \& Wallen, 2001). Based on the guidelines for this university, cooperating teachers must have at least three years of successful teaching, a valid and current teaching license, and the verbal or written recommendation by a building principal or designee. Many of the participants (118 out of 287) had taken a 3-credit, graduate-level course in supervision skills sponsored by this university and are distinguished as "Clinical Faculty." Elementary school teachers represented the highest number of cooperating teachers $(\mathrm{N}=140)$ in this population while middle school teachers represented the lowest group $(\mathrm{N}=31)$. The following charts illustrate the number of participants by grade level and clinical faculty training. Table 6

Cooperating Teachers by Grade Level

\begin{tabular}{cccc}
\hline Elementary & Middle & High & Total \\
\hline 140 & 31 & 116 & 287 \\
\hline
\end{tabular}

Table 7

Clinical Faculty Teachers by Grade Level

\begin{tabular}{cccc}
\hline Elementary & Middle & High & Total \\
\hline 79 & 3 & 36 & 118 \\
\hline
\end{tabular}


Table 8

Cooperating Teachers and Clinical Faculty Teachers

\begin{tabular}{ccc}
\hline Cooperating Teachers & Clinical Faculty teachers & Total \\
\hline 169 & 118 & 287 \\
\hline
\end{tabular}

The cooperating teachers in this sample represented 12 school districts that were within 50-mile radius of this university. However, approximately $90 \%$ of the participants represented the four school districts that are listed in Table 9. As Table 9 reveals, the majority of the cooperating teachers were from school district $C$. This was due to the close proximity between this district's schools and the university campus. There was $\$ 1400$ range of difference in per pupil spending and a range of approximately 23,000 students among these four school districts. School districts C and D are characterized as suburban school districts and $\mathrm{E}$ and $\mathrm{F}$ are characterized as urban school districts.

Table 9

Demographic Information on Cooperating Teachers' School Districts

\begin{tabular}{ccccc}
\hline $\begin{array}{c}\text { School } \\
\text { District }\end{array}$ & $\begin{array}{c}\text { Student } \\
\text { Population }\end{array}$ & $\begin{array}{c}\text { Number of } \\
\text { Schools }\end{array}$ & $\begin{array}{c}\text { Per Pupil } \\
\text { Spending }\end{array}$ & $\begin{array}{c}\text { Number of } \\
\text { Cooperating } \\
\text { Teachers }\end{array}$ \\
\hline C & 9,400 & 12 & $\$ 9400$ & 135 \\
\hline D & 12,300 & 19 & $\$ 8000$ & 67 \\
\hline E & 23,000 & 35 & $\$ 8500$ & 15 \\
\hline F & 33,000 & 45 & $\$ 8600$ & 41 \\
\hline
\end{tabular}

Instrument and Instrument Development

The participants completed a self-administered survey that the researcher modified from the Standards Assessment Inventory (SAI). The SAI was created to measure educators' perceptions on how the NSDC standards were being implemented in their school (SEDL, 2003). The modified version intended to measure cooperating 
teacher perceptions on how the role of cooperating teachers aligns with the NSDC standards.

Self-administered surveys are frequently used in research studies to gather data on the individuals completing them (Bourque \& Fielder, 2003). Surveys are used to generalize attitudes or behaviors of a sample or population. Survey information reveals opinions and practices and can describe the general characteristics or aspects of a group. This study used a cross-sectional survey design because the data was collected at one point in time (Creswell, 2003; Gall, Gall, \& Borg, 2003; Wallen \& Fraenkel, 2001). Survey methodology presents advantages and disadvantages. Surveys offer participants the advantage of completing them in stages and at their own convenience (Gall, Gall, \& Borg, 2003). They allow a researcher to cover a broad geographic region and study a large sample size. Compared to other methods, timing is another advantage of using surveys. It can be assumed that all participants receive the surveys at nearly the same time. This reduces the influence of outside or unrelated events that could impact an individual's reactions or opinions. Compared to interviews, surveys may allow participants to provide more truthful responses, especially on sensitive topics (Bourque \& Fielder, 2003). They allow a researcher to ask a series of similar questions and ask questions that have lengthy or complex category responses (Fowler, 2002). Other advantages include their economy of design and quick turn around time in data collection (Creswell, 2003).

Surveys present disadvantages and limitations. They are not able to probe and clarify research participants' inner experiences, beliefs, and attitudes (Gall, Gall, \& Borg, 2003). Self-administered surveys are dependent on respondents with good reading and 
writing skills, and require questions that are carefully designed and formatted. Surveys also rely on having participants who are motivated to complete them. Other disadvantages and limitations for the researcher include not having control over who answers the questions and not being able to exercise the quality control needed to ensure that all questions have been answered (Fowler, 2002).

Noted earlier, this study used the researcher's modified version of the Standards Assessment Inventory (SAI) entitled Cooperating Teachers and Professional Development. The SAI had 60 questions that are equally divided among the 12 standards of the NSDC, used close-ended questions, and employed a five-point Likert scale. Closed-ended questions provide answers with a pre-specified response. This form offers ease in making quantitative data analysis. It provides the researcher a more reliable way of interpreting the responses and helps the participants in providing more reliable answers (Gall, Gall, \& Borg, 2003). The NSDC standards include the following:

- learning communities

- leadership

- resources

- data-driven

- evaluation

- research-based

- design

- learning

- collaboration

- equity 
- quality teaching

- family involvement

These 12 standards are divided among the categories of context, process, and content. Each category and corresponding standard was briefly described in Chapter 2.

Standards Assessment Inventory (SAI).

The SAI was developed by the Evaluation Services of the Southwest Educational Development Laboratory (SEDL) at the request of the NSDC. The survey items were constructed by the staff of the SEDL and were reviewed and refined by four experts in NSDC standards and a focus group of teachers. This group also established the reliability and validity of this instrument (SEDL, 2003).

Initially there were 360 survey items on the SAI. By the first pilot test, this number was reduced to 100 and by the third pilot test this number was 60 . The SAI was pilot tested three times at a total of 60 schools. The results of the pilot tests concluded that this instrument has a high reliability with an alpha coefficient of .98 .

An instrument's content validity measures the extent to which the items on it represent all of the possible questions that could be asked. This is accomplished by using a panel of judges or experts who examine the instrument and determine if the items are valid and relevant to the selected area of study (Creswell, 2005). The content validity of the SAI was established by four experts in NSDC standards and a focus group of teachers. These experts provided input and feedback on survey wording and relevance of the items in representing the standards. The teacher focus group provided feedback on the survey wording and the item relevance to their experiences (SEDL, 2003). 
The SAI also has acceptable criterion-related validity. This type of validity determines if the scores on an instrument can predict scores on another outcome (Creswell, 2005). In each pilot test, a discriminant function analysis was done by comparing the teacher school ratings to the ratings of the NSDC experts. NSDC experts independently rated each school in the pilot test. This analysis concluded that the SAI has good criterion-related validity (SEDL, 2003).

However, the construct validity of this instrument does not support the 12 standards of the NSDC. A factor analysis on each pilot test revealed that this instrument has five to seven distinct categories instead of 12 . This suggests that survey items overlap among the 12 standards (SEDL, 2003).

Each of the following graphics were created for this study to show the relationship between the NSDC categories, the standards, and the SAI survey items: Figure 2

Standards Assessment Inventory (SAI)- Context Category

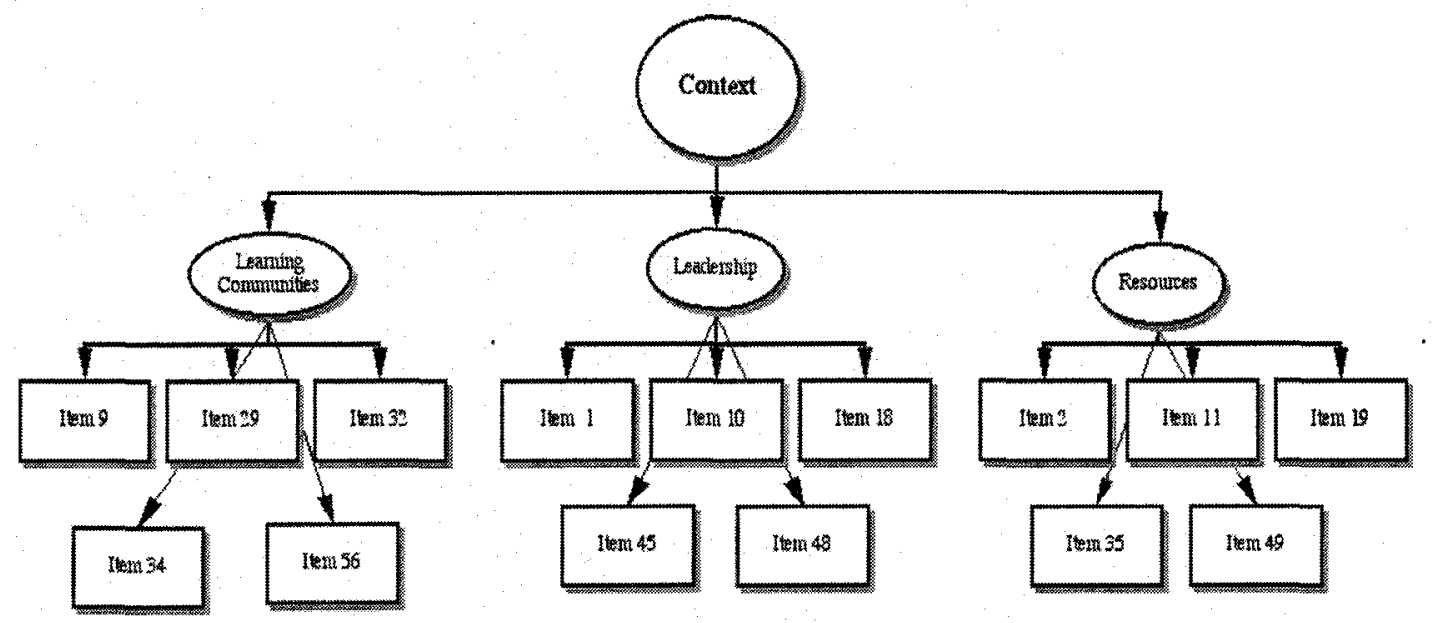


Figure 3

Standards Assessment Inventory (SAI)-Process Category

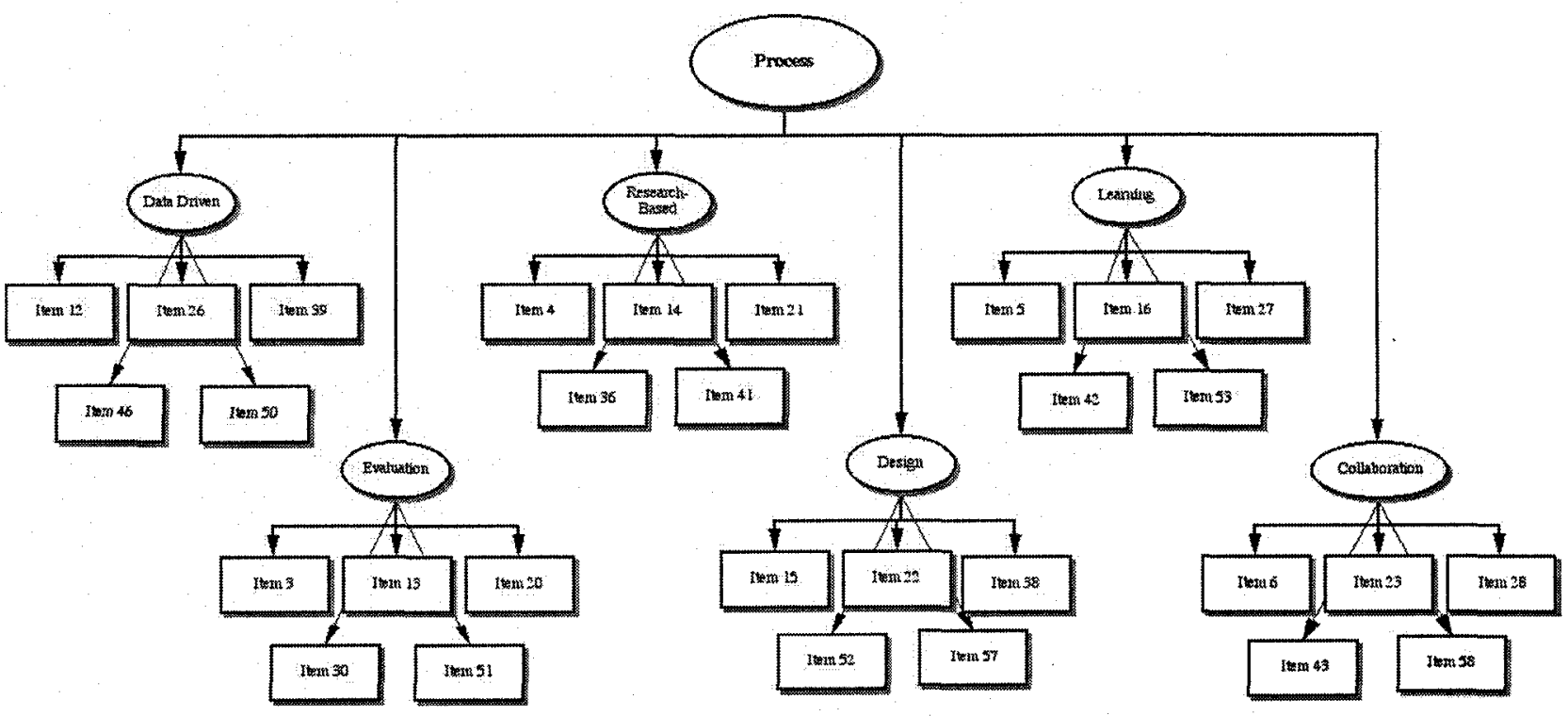

Figure 4

Standards Assessment Inventory (SAI)-Content Category

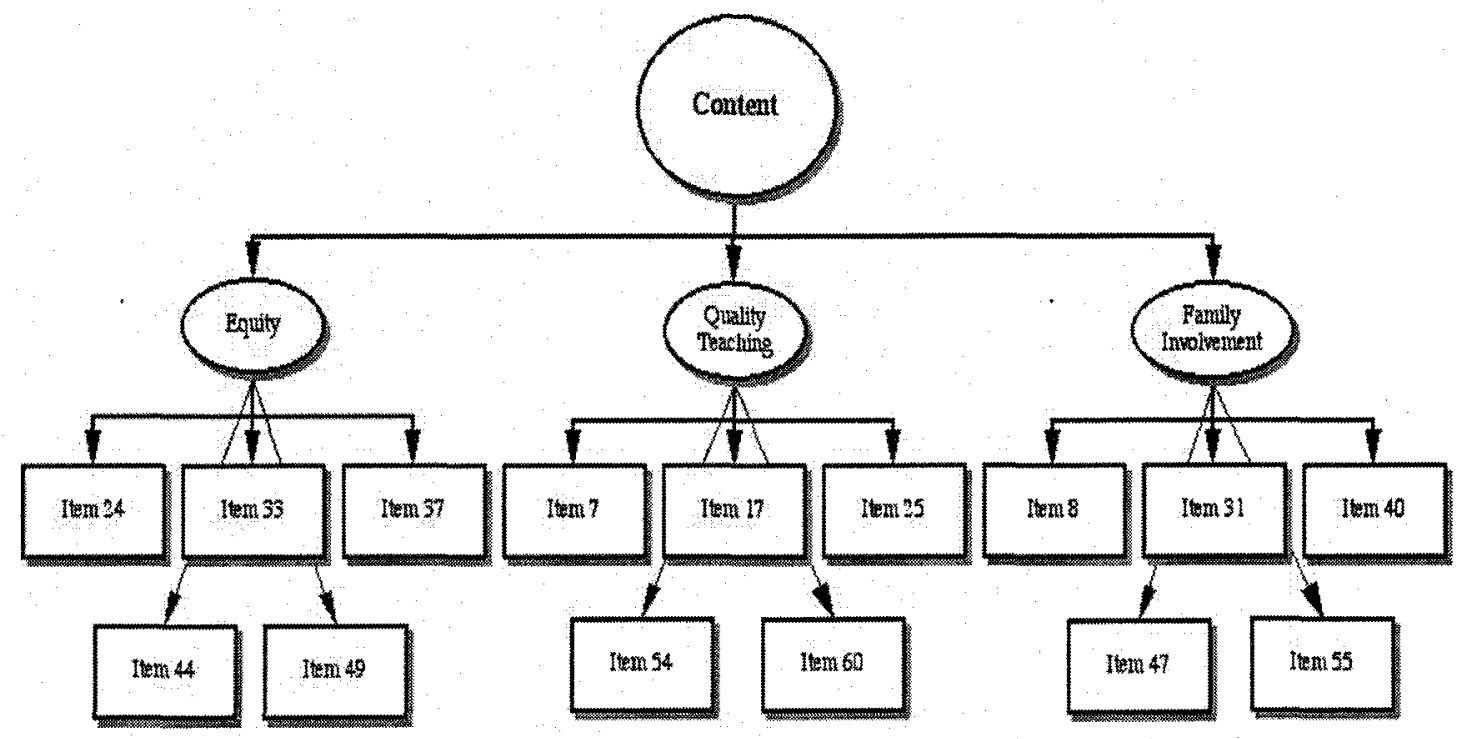




\section{Standards Assessment Inventory (SAI) modifications}

The purpose of the adapted version of the SAI was to measure how serving as a cooperating teacher aligned with the standards of the NSDC. Similar to the SAI, the adapted version used a five-point Likert scale and closed-ended questions. The following model illustrates the logic or rationale on how the items were converted.

Figure 5

Logic model on converting the SAI survey items

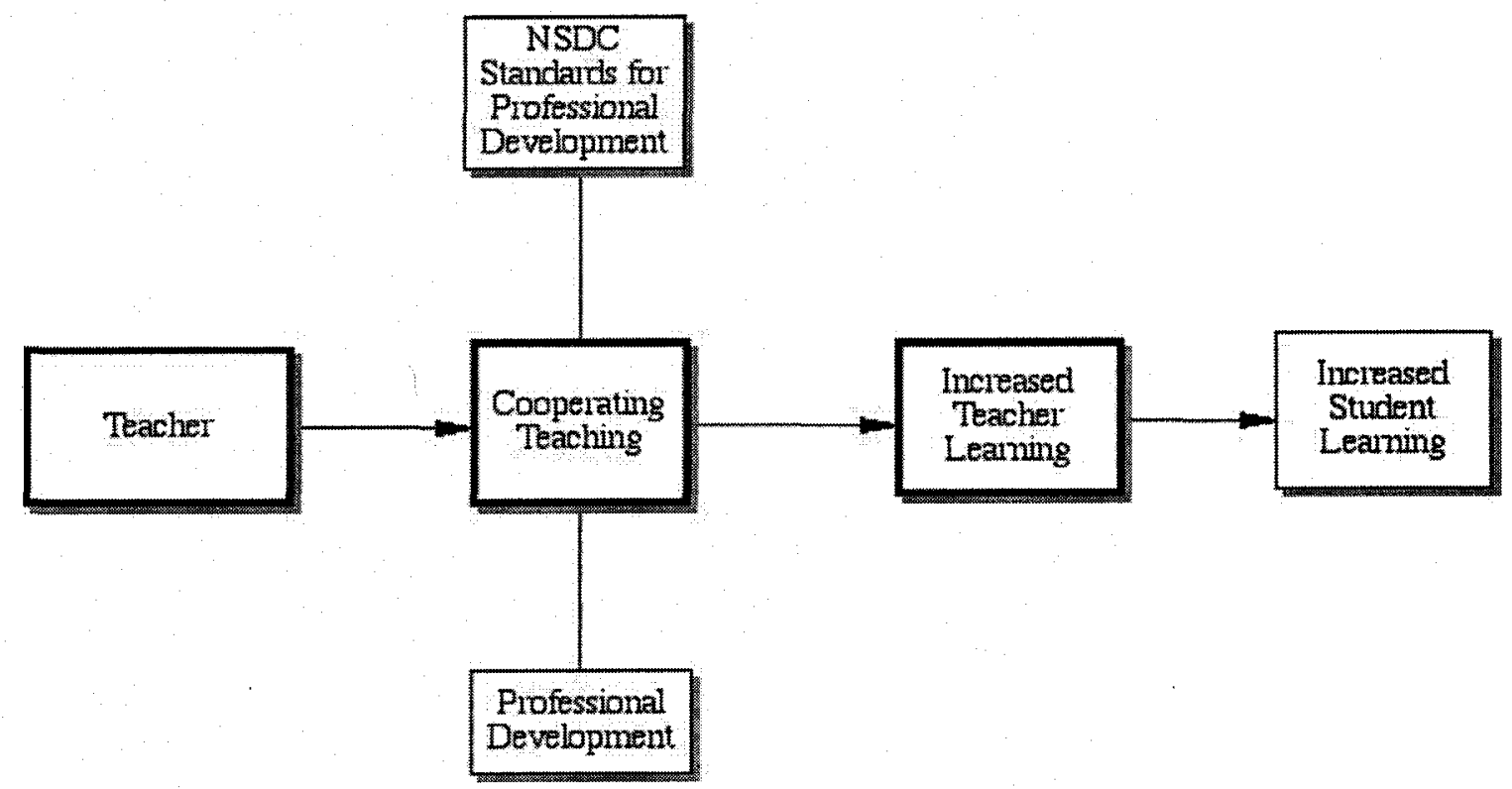

The teacher is involved in the professional development activity of cooperating teaching. The outcome for the teacher is increased teacher learning. The modified SAI survey items measured if there was an increase in teacher learning or if cooperating teaching exemplifies the best practices of professional development as defined by the NSDC. The best practices of professional development are intended to increase teacher learning. The following broad questions served as a guide for modifying each item:

- "Is the survey item intended to measure teacher learning?" 
- "Is the item intended to measure the use of a best practice of professional development?"

If the answer was yes to one of the above questions, the survey item was converted or changed by adding stems such as "Serving as a cooperating teacher..." or "Being a cooperating teacher...." Verbs such as supported, increased, provided, helped, and gained were added to help some items reflect the roles and responsibilities of being a cooperating teacher. The original and modified items have similar wording. However, the modified items have a past perfect tense since they were to measure past perceptions and were intended to reflect the intent of the original item. Appendix A shows all of the SAI survey items and indicates which ones were and were not modified. The following chart (Table 10) illustrates some of these examples.

Table 10

Examples of original and modified items

\begin{tabular}{ll}
\hline \multicolumn{1}{c}{ Original Item } & \multicolumn{1}{c}{ Modified Item } \\
\hline $\begin{array}{l}\text { Teachers use student data when discussing } \\
\text { instruction and curriculum. }\end{array}$ & $\begin{array}{l}\text { As a cooperating teacher, my student } \\
\text { teacher and I have used student data when } \\
\text { discussing instruction and curriculum. }\end{array}$ \\
\hline $\begin{array}{l}\text { Teachers at our school have opportunities } \\
\text { to learn how to use technology to enhance } \\
\text { instruction. }\end{array}$ & $\begin{array}{l}\text { Being a cooperating teacher has provided } \\
\text { me opportunities to learn how to use } \\
\text { technology to enhance my instruction. }\end{array}$ \\
\hline
\end{tabular}

The researcher was able to convert 49 of the 60 SAI survey items to reflect cooperating teaching. The following chart illustrates the number of converted and not converted items by NSDC category and standard. 
Table 11

Number of converted and non-converted SAI items

\begin{tabular}{|c|c|c|c|}
\hline NSDC Category & NSDC Standard & Converted & Not converted \\
\hline \multirow[t]{4}{*}{ Context } & $\begin{array}{l}\text { Learning } \\
\text { communities }\end{array}$ & 4 & 1 \\
\hline & Leadership & 4 & 1 \\
\hline & Resources & 4 & 1 \\
\hline & Total & 12 & 3 \\
\hline \multirow[t]{7}{*}{ Process } & Data driven & 3 & 2 \\
\hline & Evaluation & 4 & 1 \\
\hline & Research based & 3 & 2 \\
\hline & $\begin{array}{l}\text { Design and } \\
\text { strategies }\end{array}$ & 5 & 0 \\
\hline & Learning & 5 & 0 \\
\hline & Collaboration & 4 & 1 \\
\hline & Total & 24 & 6 \\
\hline \multirow[t]{4}{*}{ Content } & Equity & 5 & 0 \\
\hline & Quality Teaching & 5 & 0 \\
\hline & $\begin{array}{l}\text { Family } \\
\text { Involvement }\end{array}$ & 3 & 2 \\
\hline & Total & 13 & 2 \\
\hline \multicolumn{2}{|c|}{ Total of all categories } & 49 & 11 \\
\hline
\end{tabular}

Based on the above chart, the following figures were created for this research to illustrate the new relationship between the modified survey items by NSDC category and standard. Please note that survey item numbers in these figures represent the modified survey. 
Figure 6

Modified Standards Assessment Inventory (SAI)-Context Category

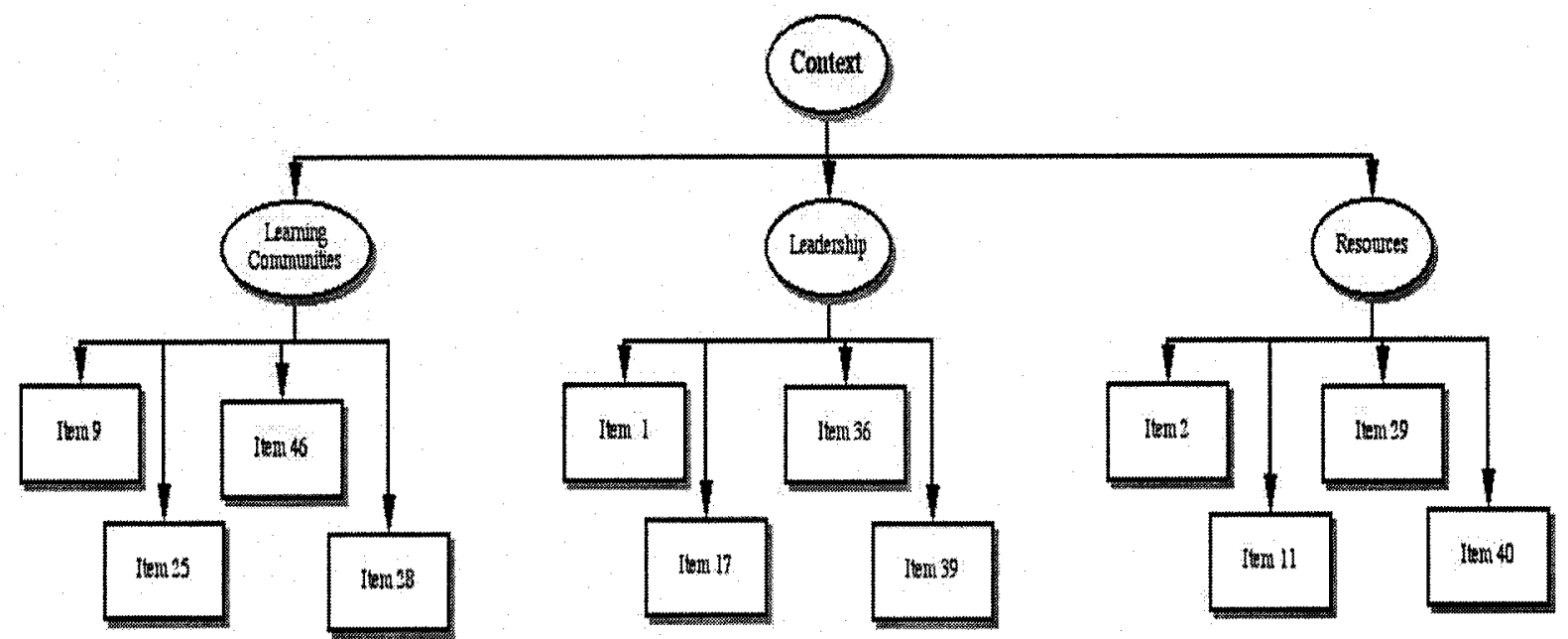

Figure 7

Modified Standards Assessment Inventory (SAI - Process Category

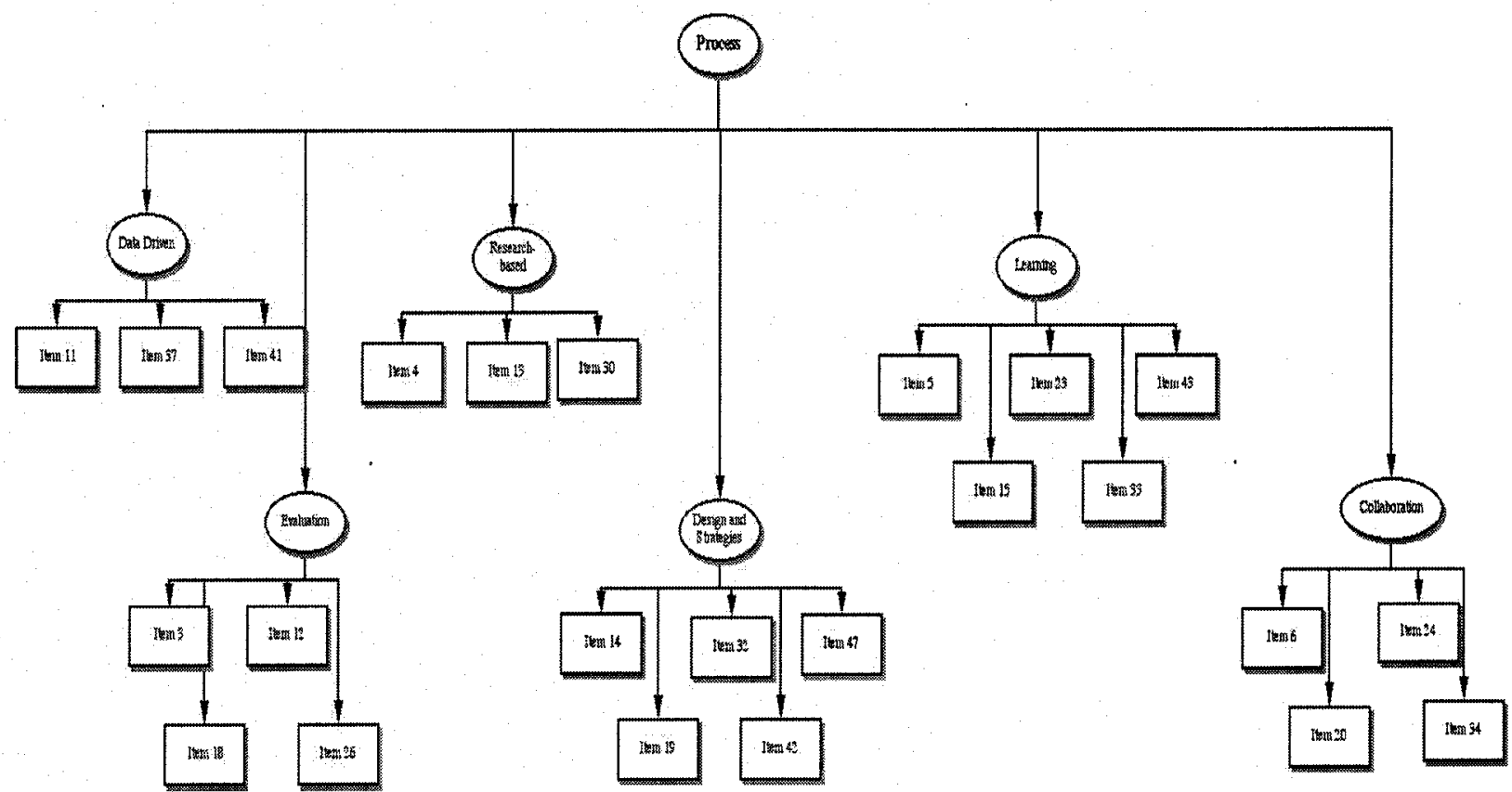


Figure 8

Modified Standards Assessment Inventory (SAI)- Content Category

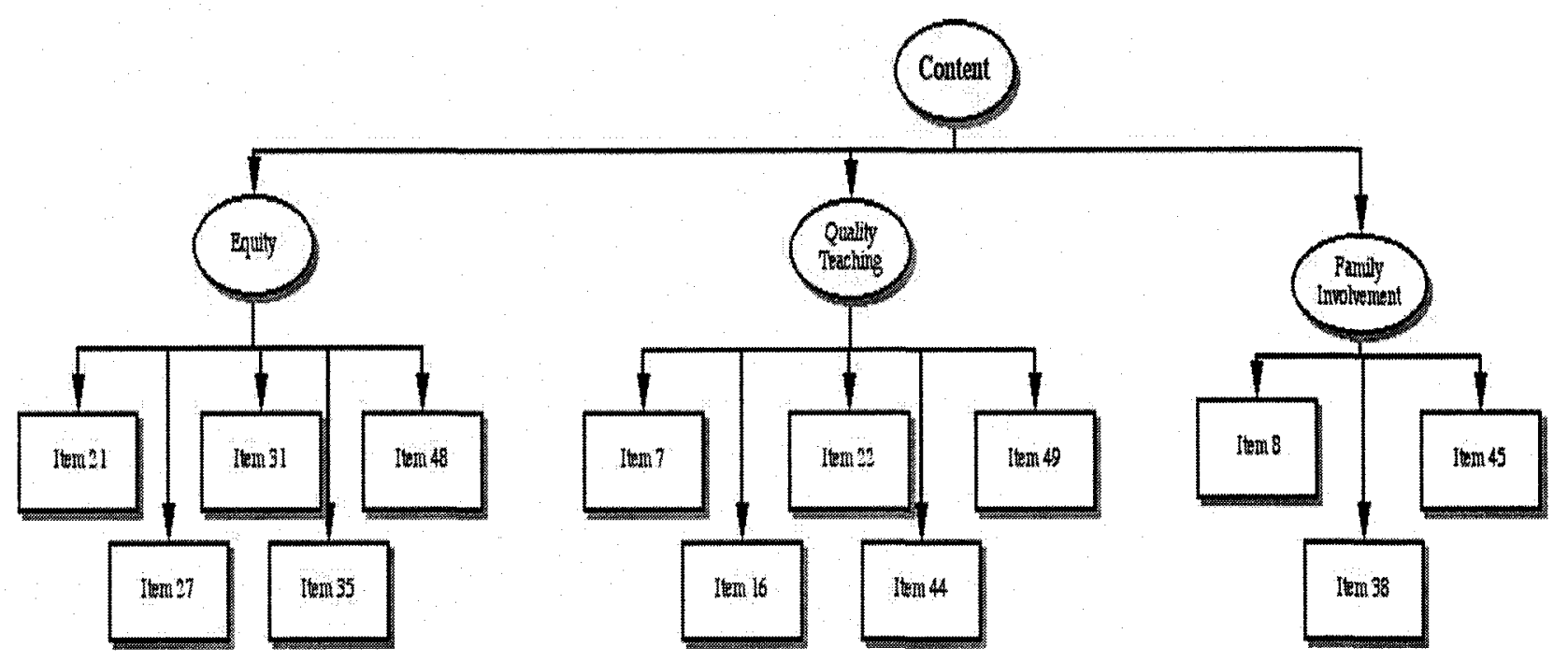

Refining and validating the instrument occurred in two phases. In the first phase, a group of experts with extensive knowledge in professional development and cooperating teaching independently reviewed the instrument for content validity. Each expert was asked if the 49 converted survey items should be eliminated, modified, or kept as written. They were also asked to make wording suggestions. The group felt that none of these 49 items should be eliminated. They offered wording suggestions to help refine these items. These suggestions were incorporated into the survey items.

In the second phase, a group current and former cooperating teachers completed the survey and were asked if survey items, wording, and/or formatting needed clarification. There suggestions and comments were incorporated into the final survey.

The first section of the modified version requested each respondents' demographic and background information. The requested data included:

- gender 
- ethnicity

- grade-level assignment (elementary, middle or high)

- highest degree earned

- years of full-time teaching

- number of supervised student teachers

- type of training to prepare for cooperating teaching (e.g., orientation meeting, mentor training, supervision training)

The second section contained the 49 survey items. The response categories were strongly agree (5), agree (4), neutral (3), disagree (2), and strongly disagree (1). A copy of the survey is found in Appendix B.

\section{Data Collection}

Data collection involves an interaction between the researcher and respondents (Fowler, 2002). To facilitate this process, the participants received a brief letter from a university faculty member that explained the study's purpose and solicited their cooperation. Contacting the participants before the questionnaire is sent can increase the survey response rate (Gall, Gall, \& Borg, 2003).

Approximately a week later, the researcher mailed the cover letter, survey, and a postage paid self-return envelope to the sample population. The cover letter briefly stated the study's purpose and importance. It addressed participant confidentiality and the procedures for completing and returning the survey. Three days prior to the survey's deadline, a third mailing in the form of a postcard served as a thank you note and survey reminder. Copies of the above correspondences are in Appendices C and D. 


\section{Data Analysis}

The demographic information on the survey was analyzed using descriptive statistics and frequency counts. Descriptive statistics were provided for survey items, standards, and each NSDC category. The overall survey mean was also determined and labeled professional development since it represented a combination of the NSDC categories (context, process, and content). A score that showed agreement in the overall average and in each category determined if cooperating teaching is a role that aligns with the NSDC standards.

One way analysis of variance (ANOVA) tests was used to determine if there were differences among cooperating teachers. One analysis used grade level assignment as an independent variable and the other analysis used clinical faculty training as an independent variable. The dependent variables for each test were professional development, context, process, and content. An ANOVA determines if there are significant differences among two or more groups by comparing the groups' mean scores. It can be used when there is one dependent variable and one or more independent variables (Weinfurt, 2005).

Multiple regression analyses were used to predict cooperating teachers' perceptions of this role as a professional development activity based on their:

- experience level (degree earned, years of full time teaching, and number of student teachers supervised)

- preparation (no training, informal meeting, student teacher orientation, mentorship training, or clinical faculty training) 
- demographics (age, grade level assignment, ethnicity, gender, currently has a student teacher, highest degree)

The descriptors in the above classifications (experience, preparation, and demographics) were the predictor variables. The dependent variables for these analyses were professional development, context, process, and content. Multiple regression statistical analysis is widely used in research for examining the combined relationship between two or more predictor variables and a criterion variable (Gall, Gall, \& Borg, 2003). This form of analysis is used for attempting to predict events or behaviors and is used for attempting to explain or understand the nature of a phenomenon (Licht, 2005).

SPSS 14 was the analytical tool. Table 12 outlines the timeframe for data collection and analysis. The next section will show the data analysis matrix.

Table 12

Timeline for data collection and analysis

\begin{tabular}{ll}
\hline Time frame & \\
\hline January 2007 & Seek approval from Human Subjects Committee \\
& Instrument pilot testing \\
& - Expert panel review \\
& Precontacted participants with a letter \\
& A week later-mailed cover letter and survey \\
& 4 to 8 days later, sent survey thank you note/ \\
& reminder \\
\hline February 2007 & Analyzed data and presented \\
& preliminary findings to doctoral committee \\
\hline
\end{tabular}


Data analysis matrix.

The following charts illustrate how the data were analyzed by subquestion and

NSDC category.

Table 13

Data analysis by research questions

\begin{tabular}{lc}
\hline \multicolumn{1}{c}{ Research questions } & \multicolumn{1}{c}{ Analysis } \\
\hline Primary Research Question & Descriptive Statistics \\
Using the standards of the National Staff Development & \\
Council (NSDC) as a survey framework, how do & \\
cooperating teachers perceive this role as a professional & \\
development activity? & \\
\hline
\end{tabular}

1. Does the role of cooperating teaching support the Descriptive Statistics context standards needed for professional development?

NSDC category- Context

2. Does the role of cooperating teaching support the Descriptive Statistics process standards needed for professional development?

NSDC category- Process

3. Does the role of cooperating teaching support the Descriptive Statistics content standards needed for professional development?

\section{NSDC category- Content}

4. To what degree do cooperating teachers at different ANOVA grade levels (elementary, middle, and high) have different perceptions of student teacher supervision as a professional development activity?

5. What is the relationship between cooperating teachers' experience levels (degree earned, years of full time teaching, and number of student teachers supervised) in their perceptions of student teacher supervision as a professional development activity? 
6. What is the relationship between cooperating

Multiple Regression

teachers with different preparation (no training,

informal meeting, student teacher orientation,

mentorship training, or clinical faculty training) in

their perceptions of student teacher supervision as a

professional development activity?

7. What demographic factors help predict how cooperating teachers perceive student teacher supervision as a professional development activity?

Multiple Regression

Table 14

Data analysis by participant demographics and NSDC standards

\begin{tabular}{ll}
\hline Questions & Analysis \\
\hline $\begin{array}{l}\text { What are the demographics of the sample } \\
\text { population? (grade level assignment, gender, } \\
\text { ethnicity, age, highest degree earned, years of full } \\
\text { time teaching, number of student teachers }\end{array}$ & $\begin{array}{l}\text { Descriptive Statistics } \\
\text { supervised, and type of training) }\end{array}$ \\
\hline $\begin{array}{l}\text { NSDC standard- Learning communities } \\
\text { Do cooperating teachers use learning }\end{array}$ & Descriptive Statistics \\
communities? & \\
\hline $\begin{array}{l}\text { NSDC standard- Leadership } \\
\text { Does the role of cooperating teacher provide }\end{array}$ & \\
recognition and support of your leadership? & Descriptive Statistics \\
\hline $\begin{array}{l}\text { NSDC standard- Resources } \\
\text { Do cooperating teachers receive resources that }\end{array}$ & Descriptive Statistics \\
help support their learning and collaboration? & \\
\hline $\begin{array}{l}\text { NSDC standard- Data-driven } \\
\text { Does the role of cooperating teacher provide }\end{array}$ & Descriptive Statistics \\
opportunities to use data driven decisions? & \\
\hline $\begin{array}{l}\text { NSDC standard-Evaluation } \\
\text { Does the role of cooperating teacher provide } \\
\text { opportunities to make evaluative decisions? }\end{array}$ & \\
\hline $\begin{array}{l}\text { NSDC standard- Research-based } \\
\text { Does the role of cooperating teacher provide } \\
\text { opportunities to apply research-based decisions? }\end{array}$ & \\
\hline $\begin{array}{l}\text { NSDC standard- Design and Strategy } \\
\text { Do cooperating teachers design and use learning } \\
\text { strategies appropriate for the intended goal? }\end{array}$ & \\
\hline
\end{tabular}


NSDC standard- Learning

Does the role of cooperating teacher provide

Descriptive Statistics

opportunities to apply knowledge about human

learning and change?

NSDC standard- Collaboration Descriptive Statistics

Does the role of cooperating teacher provide

knowledge on learning collaborative skills?

NSDC standard- Equity Descriptive Statistics

Does the role of cooperating teacher provide

opportunities to understand and appreciate all

students?

NSDC standard- Teacher quality Descriptive Statistics

Does the role of cooperating teacher provide

opportunities to improve teacher quality?

NSDC standard- Family involvement Descriptive Statistics

Does the role of cooperating teacher provide

knowledge in involving families?

\section{Ethical Safeguards}

This research was approved by the Human Subjects Review Committee at the

College of William and Mary and was conducted in a manner that reflected the honor and integrity of the School of Education and the college policies. The anonymity of both of the participants and school systems was protected. The correspondences to the sample population noted that participation was voluntary and confidential. 
Chapter IV: Results

Examining how serving as cooperating teaching aligned with the standards of the National Staff Development Council (NSDC) was the purpose of this study. The researcher adapted the Standards Assessment Inventory (SAI) to measure cooperating teachers' perceptions of how student teacher supervision was linked to these professional development standards. This survey was titled Cooperating Teachers and Professional Development. The NSDC standards represent the best practices of professional development and are divided into 12 standards and 3 categories.

Descriptive statistics and frequency counts were used to show the sample size, survey response rate and population demographics. They displayed cooperating teachers' agreement or disagreement on how this responsibility utilized the NSDC categories and standards. The analysis of variance (ANOVA) results showed if there were differences in cooperating teachers' perceptions based on grade level assignment and participation in clinical faculty training. Multiple regression analyses revealed if there were significant predictors in cooperating teachers' perceptions based on their preparation, demographics, and teaching experience. Statistical Package for Social Sciences (SPSS) 14 was the statistical analysis tool.

\section{Return Rate and Demographic Information}

The Cooperating Teachers and Professional Development survey was mailed to $\mathrm{K}-12$ cooperating teachers in 12 school districts that were within a 50 mile radius of the university. 184 out of the 287 participants responded to this self-administered survey which yielded an overall return rate of $64 \%$. Three of their surveys were eliminated and not included in the data analysis because majority of the survey items were incomplete. 
As seen in Table 15, the response rates based on grade level totals were nearly identical. The survey response rates showed representative groups based on grade level assignment. For example, $40 \%$ of the sample population taught high school and high school teachers represents $40 \%$ of the total number of returned surveys.

Table 15

Frequency and Percentages of Original Sample Size and Response Rate by Grade Level

\begin{tabular}{llllll}
\hline Grade Level & $\begin{array}{l}\text { Original } \\
\text { sample } \\
\text { size }\end{array}$ & $\begin{array}{l}\text { Percentage } \\
\text { of total } \\
\text { sample }\end{array}$ & $\begin{array}{l}\text { Number of } \\
\text { returned } \\
\text { surveys }\end{array}$ & $\begin{array}{l}\text { Survey } \\
\text { response } \\
\text { rate of } \\
\text { grade level }\end{array}$ & $\begin{array}{l}\text { Percentage of } \\
\text { total number of } \\
\text { respondents }\end{array}$ \\
\hline Elementary K-5 & 140 & $48 \%$ & 87 & $62 \%$ & $48 \%$ \\
\hline Middle School 6-8 & 31 & $11 \%$ & 19 & $61 \%$ & $10 \%$ \\
\hline High School 9-12 & 116 & $40 \%$ & 73 & $63 \%$ & $40 \%$ \\
\hline No Response & & & 2 & & $1 \%$ \\
\hline
\end{tabular}

Table 16 shows the response rates based on gender and clinical faculty training. Clinical faculty teachers represented $41 \%$ of the sample population and $61 \%$ of the total number of returned surveys. However, non-clinical faculty teachers or cooperating teachers represented $59 \%$ of the total sample population, but represented only $39 \%$ of the survey respondents.

The over representation of clinical faculty members could be due to a variety of factors. Clinical faculty members may have a greater commitment and connection to university associated with this study. These individuals have completed a graduate level supervision course sponsored by the institution. Clinical faculty members receive the status of being adjunct faculty members and receive a higher honorarium than nonclinical faculty teachers. Other reasons for the over representation include the researcher's previous association with the clinical faculty program and the pre-contact 
letter from the clinical faculty director. Please note that all participants received the same pre-contact and cover letter. No further inquiry was made for the over representation of clinical faculty members.

Although the surveys were returned anonymously, the above reasons could have influenced the results. Clinical faculty teachers may have felt an obligation to make statements that did not reflect their opinions.

Table 16

Frequency and Percentages of Original Sample Size and Response Rate by Gender

\begin{tabular}{lllll}
\hline & $\begin{array}{l}\text { Original } \\
\text { Sample } \\
\text { Size }\end{array}$ & $\begin{array}{l}\text { Percentage of } \\
\text { total sample }\end{array}$ & $\begin{array}{l}\text { Number of } \\
\text { returned } \\
\text { surveys }\end{array}$ & $\begin{array}{l}\text { Response rate } \\
\text { based total number } \\
\text { of respondents }\end{array}$ \\
\hline Gender & & & & $77 \%$ \\
\hline Female & 231 & $77.3 \%$ & 140 & $19 \%$ \\
\hline Male & 56 & $18.8 \%$ & 34 & \\
\hline No Response & & & 7 & $61 \%$ \\
\hline Clinical Faculty & 118 & $41 \%$ & 110 & $39 \%$ \\
\hline Cooperating Teachers & 169 & $59 \%$ & 70 & \\
\hline No Response & & & 11 &
\end{tabular}

The majority of the participants were female (77.3\%), Caucasian $(83.4 \%)$, and ranged in age from 45-54 (32.8\%). The group was almost evenly divided between grades $\mathrm{K}-5(\mathrm{~N}=87)$ and grades 6-12 $(\mathrm{N}=92)$. These were experienced teachers when measured by their education and classroom experience. Most of the respondents had advanced degrees $(60.3 \%)$ and over 20 years of classroom experience (42.5\%). Table 17 shows the frequency and percentages of cooperating teachers by gender, ethnicity, age, highest degree, and classroom experience. 
Table 17

Frequency and Percentages of Participants by Gender, Ethnicity, Age, Highest Degree, and Years of Teaching*

\begin{tabular}{|c|c|c|c|c|c|}
\hline & $f$ & $\%$ & & $f$ & $\%$ \\
\hline & & & & & \\
\hline Gender & & & Highest Degree & & \\
\hline Female & 140 & 77.3 & $\mathrm{BA} / \mathrm{BS}$ & 70 & 38.7 \\
\hline Male & 34 & 18.8 & MA/MS & 82 & 45.3 \\
\hline \multirow[t]{3}{*}{ No Response } & 7 & 3.9 & $\mathrm{MA} / \mathrm{MS}+30$ & 23 & 12.7 \\
\hline & & & Ed.S & 3 & 1.1 \\
\hline & & & Ed.D/Ph.D & 1 & .6 \\
\hline Ethnicity & $f$ & $\%$ & No Response & 2 & 1.1 \\
\hline $\begin{array}{l}\text { African- } \\
\text { American }\end{array}$ & 12 & 6.6 & & & \\
\hline Asian & 2 & 1.1 & & & \\
\hline Caucasian & 151 & 83.4 & Years of teaching & $f$ & $\%$ \\
\hline Hispanic & 5 & 2.8 & 3 to 5 & 5 & 2.8 \\
\hline Other & 4 & 2.2 & 6 to 10 & 40 & 22.1 \\
\hline \multirow[t]{3}{*}{ No Response } & 7 & 3.9 & 11 to 15 & 32 & 17.7 \\
\hline & & & 16 to 20 & 24 & 13.3 \\
\hline & & & $20+$ & 77 & 42.5 \\
\hline Age & $f$ & $\%$ & No Response & 3 & 1.7 \\
\hline $25-34$ & 22 & 12.2 & & & \\
\hline $35-44$ & 50 & 28.2 & & & \\
\hline $45-54$ & 59 & 32.6 & \multicolumn{3}{|c|}{ Participants currently with a student teacher } \\
\hline 55 and over & 48 & 26.5 & Yes & 81 & 44.8 \\
\hline \multirow[t]{2}{*}{ No Response } & 1 & .6 & No & 100 & 55.2 \\
\hline & & & No Response & 0 & 0 \\
\hline & & & & & \\
\hline & & & & & \\
\hline & & & & & \\
\hline
\end{tabular}

* Total for all groups $=181$ 
The respondents had supervised a total of 949 student teachers. This yields an average of 5.2 student teachers per cooperating teacher. The range in number of student teachers supervised was from one to 32 . The largest group had supervised one or two student teachers $(34.8 \%)$ and $81(44.8 \%)$ of the participants were currently supervising a student teacher. Table 18 displays the frequency, percentages and the range of student teachers supervised.

Table 18

Frequency and Percentages of the Student Teachers Supervised by the Participants

\begin{tabular}{lll}
\hline $\begin{array}{l}\text { Student teachers } \\
\text { supervised }\end{array}$ & $f$ & $\%$ \\
\hline $1-2$ & 63 & 34.8 \\
\hline $3-4$ & 40 & 22.1 \\
\hline $5-6$ & 24 & 13.3 \\
\hline $7-8$ & 21 & 11.6 \\
\hline $9-10$ & 18 & 10.0 \\
\hline $11-12$ & 3 & 1.7 \\
\hline $13-14$ & 2 & 1.2 \\
\hline $15-16$ & 3 & 1.7 \\
\hline $17-18$ & - & - \\
\hline $19-20$ & 6 & 3.4 \\
\hline 32 & 1 & .6 \\
\hline Total & 181 & 100 \\
\hline
\end{tabular}


The majority of this sample had participated in a type of cooperating teacher preparation. These results are listed in Table 19. Informal meetings with a college or university representative had been attended by 165 respondents $(91.2 \%)$ and $105(69.1 \%)$ respondents had attended a student orientation meeting(s). The respondents had attended clinical faculty training $(60.8 \%)$ and training on mentoring new teachers $(59.7 \%)$. Eight participants revealed other experiences that prepared them for this responsibility. They included taking graduate courses, attending workshops and conferences, and reading professional journals.

Table 19

Frequency and Percentages of Participants by Cooperating Teacher Preparation

\begin{tabular}{|c|c|c|c|c|c|c|}
\hline & \multicolumn{2}{|c|}{ Yes } & \multicolumn{2}{|c|}{ No } & \multicolumn{2}{|c|}{ No Response } \\
\hline & $f$ & $\%$ & $f$ & $\%$ & $f$ & $\%$ \\
\hline $\begin{array}{l}\text { Informal meeting(s) or } \\
\text { conversation(s) with a } \\
\text { college or university } \\
\text { representative }\end{array}$ & 165 & 91.2 & 15 & 8.3 & 1 & .9 \\
\hline $\begin{array}{l}\text { Student teacher } \\
\text { orientation meeting }(\mathrm{s})\end{array}$ & 125 & 69.1 & 51 & 28.2 & 5 & 2.8 \\
\hline $\begin{array}{l}\text { Clinical faculty } \\
\text { training }\end{array}$ & 110 & 60.8 & 70 & 38.7 & 1 & .6 \\
\hline $\begin{array}{l}\text { Training on how to } \\
\text { mentor new teachers, } \\
\text { provided by a school } \\
\text { division }\end{array}$ & 108 & 59.7 & 69 & 38.1 & 4 & 2.2 \\
\hline Other & 8 & 4.4 & 23 & 12.7 & 150 & 82.9 \\
\hline
\end{tabular}


Analysis of Research Questions

Primary Research Question: Using the standards of the National Staff Development Council (NSDC) as a survey framework, how do cooperating teachers' perceive student teacher supervision as a professional development activity?

Based on the descriptive statistics in Table 20, cooperating teachers' moderately agreed $(M=3.7)$ that student teacher supervision was a professional development activity. This cumulative average was composed of 152 participants because 29 did not complete all survey items. Further analysis showed that 20 respondents did not complete one item, and six respondents did not complete two items. Two respondents did not respond to three items, and one did not respond to five items. The results of all survey items are listed in Appendix E.

Table 20

Descriptive Statistics for Professional Development

\begin{tabular}{|c|c|c|c|c|c|c|c|}
\hline & \multirow[t]{2}{*}{$\mathrm{N}$} & \multicolumn{2}{|c|}{ No Response } & \multirow[t]{2}{*}{ Min. } & \multirow[t]{2}{*}{ Max. } & \multirow[t]{2}{*}{$\mathrm{M}$} & \multirow[t]{2}{*}{$\mathrm{SD}$} \\
\hline & & $\mathrm{N}$ & $\%$ & & & & \\
\hline $\begin{array}{l}\text { Professional } \\
\text { Development }\end{array}$ & 152 & 29 & 16.9 & 2 & 5 & 3.7 & .421 \\
\hline
\end{tabular}

The survey consisted of a five-point scale, where one equals strongly disagree and five equals strongly agree. The words "moderately agreed" were used to describe the cumulative average $(M=3.7)$ because it fell roughly in the mid-point range of 3.5 to 3.99 . As listed in Table 21, seven distinct ranges were developed to help classify the descriptive statistics. This .5 range for the scale was further justified by the standard deviation for the survey results, which was .421 . 
The subsequent questions will show that the averages for the NSDC categories (context, process, and process) fell within the moderately agree range. The following questions will reveal that the average for one standard was in the agree range, eight standards were in the moderately agree range and three standards were in the neutral range. No averages fell in the strongly agree, moderately disagree, disagree, and strongly disagree ranges.

Table 21

Classifications for NSDC Category and Standard Averages

\begin{tabular}{ll}
\hline $\begin{array}{l}\text { Nominal categories for analysis of } \\
\text { survey responses }\end{array}$ & Range Averages \\
\hline Strongly Agree & $4.50-5.00$ \\
\hline Agree & $4.00-4.49$ \\
\hline Moderately Agree & $3.50-3.99$ \\
\hline Neutral & $2.50-3.49$ \\
\hline Moderately Disagree & $2.00-2.49$ \\
\hline Disagree & $1.50-1.99$ \\
\hline Strongly Disagree & $1.00-1.49$ \\
\hline
\end{tabular}

Research Question 1: Does the role of cooperating teaching support the context standards needed for professional development?

This question was addressed through descriptive statistics. Of the 49 survey items, 12 measured if cooperating teaching supported the context standards needed for a professional development activity. These items were evenly divided among the context standards: learning communities, leadership, and resources. The context of professional development involves the organizational and cultural supports and is characterized by who, what, when, where, and why of the professional development.

Based on the classifications described in the previous question, cooperating teachers moderately agreed $(M=3.84)$ that this role supported the context of professional 
development. Cooperating teachers agreed that this activity used learning communities $(M=4.14)$ which entails regularly working with others on issues related to school.

Cooperating teachers moderately agreed that this role provided recognition and support from their leadership $(M=3.74)$ and had resources that help support their learning and collaboration ( $M=3.64)$. Table 22 shows the descriptive statistics for the context category and standards.

Table 22

Descriptive Statistics for Context Category and Standards

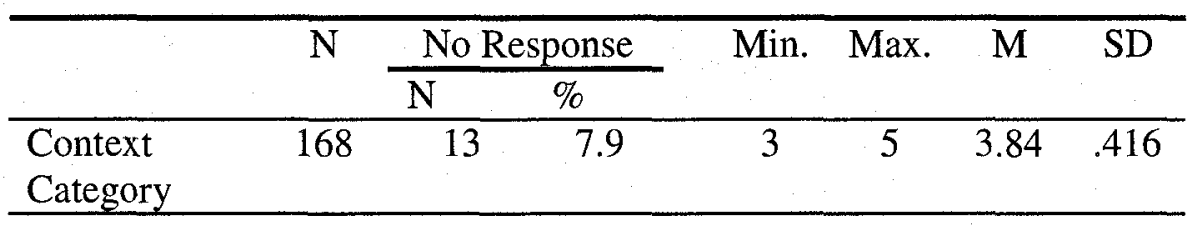

\begin{tabular}{llllllll}
\hline Standards & & & & & & & \\
\hline $\begin{array}{l}\text { Learning } \\
\text { Communities }\end{array}$ & 178 & 3 & 1.7 & 2 & 5 & 4.14 & .455 \\
\hline Leadership & 174 & 7 & 4.5 & 2 & 5 & 3.74 & .703 \\
\hline Resources & 178 & 3 & 1.7 & 2 & 5 & 3.64 & .508 \\
\hline
\end{tabular}


Research Question 2: Does the role of cooperating teaching support the process standards needed for professional development?

Descriptive statistics showed moderate agreement $(M=3.60)$ that cooperating teaching supported the process of professional development. This category had the largest number of survey items $(\mathrm{N}=24)$ and professional development standards $(\mathrm{N}=6)$. The process category was concerned with how the professional development learning activities areas are planned, followed-up, and carried out.

Noted previously, survey averages were categorized into distinct categories. Evaluation, collaborative skills, data driven decision making, and learning are the NSDC standards that fell within the moderately agree range. Serving as a cooperating teacher provided opportunities for making evaluative decisions $(\mathrm{M}=3.72)$ and provided knowledge about learning collaborative skills $(M=3.68)$. This role presented opportunities for making data driven decisions ( $M=3.77)$ and applying knowledge about human learning and change $(M=3.77)$.

However, there was a neutral response regarding how cooperating teaching helped a person make research-based decisions $(M=3.13)$ and how the role created chances for using learning strategies appropriate for an intended goal $(M=3.48)$. Research-based also had the lowest average of the 12 standards. Table 23 shows the descriptive statistics for the process category and standards. 
Table 23

Descriptive Statistics for Process Category and Standards

\begin{tabular}{|c|c|c|c|c|c|c|c|}
\hline & \multirow[t]{2}{*}{$\mathrm{N}$} & \multicolumn{2}{|c|}{ No Response } & \multirow[t]{2}{*}{ Min. } & \multirow[t]{2}{*}{ Max. } & \multirow[t]{2}{*}{$\mathrm{M}$} & \multirow[t]{2}{*}{ SD } \\
\hline & & $\mathrm{N}$ & $\%$ & & & & \\
\hline $\begin{array}{l}\text { Process } \\
\text { Category }\end{array}$ & 169 & 12 & 7.3 & 2 & 5 & 3.60 & .432 \\
\hline \multicolumn{8}{|l|}{ Standards } \\
\hline Data Driven & 181 & 0 & 0 & 2 & 5 & 3.77 & .629 \\
\hline Evaluation & 180 & 1 & 1.1 & 2 & 5 & 3.72 & .546 \\
\hline $\begin{array}{l}\text { Research- } \\
\text { based }\end{array}$ & 180 & 1 & 1.1 & 1 & 5 & 3.13 & .704 \\
\hline $\begin{array}{l}\text { Design and } \\
\text { Strategy }\end{array}$ & 175 & 6 & 3.9 & 2 & 5 & 3.48 & .528 \\
\hline Learning & 177 & 4 & 2.8 & 2 & 5 & 3.77 & .509 \\
\hline Collaboration & 180 & 1 & 1.1 & 2 & 5 & 3.68 & .550 \\
\hline
\end{tabular}


Research Question 3: Does the role of cooperating teaching support the content standards needed for professional development?

Based on the classifications from the previous questions, cooperating teachers moderately agreed $(M=3.67)$ that this role supported the content needed for professional development. This category was measured by 13 survey items. Cooperating teachers moderately agreed that this role provided opportunities for improving teacher quality $(M=3.99)$ and supported their understanding and appreciation for all students $(M=3.67)$. However, there was neutral response to how cooperating teaching provided knowledge on involving families $(M=3.34)$. The results of the content categories and standards are seen in Table 24.

The content category fostered the belief that professional development should transmit knowledge and skills that help educators improve student learning. Content standards advocated that the best practices in professional development should raise educators' content knowledge, instructional strategies and methods for increasing family involvement.

Table 24

Descriptive Statistics for Content Category and Standards

\begin{tabular}{lccccccc}
\hline & $\mathrm{N}$ & \multicolumn{2}{c}{ No Response } & Min. & Max. & M & SD \\
\cline { 3 - 8 } & & $\mathrm{N}$ & $\%$ & & & & \\
\hline Content & 169 & 12 & 7.3 & 2 & 5 & 3.67 & .496 \\
Category & & & & & & & \\
\hline & & & & & & & \\
\hline Standards & & & & & & & \\
\hline Equity & 174 & 7 & 4.5 & 2 & 5 & 3.67 & .597 \\
\hline $\begin{array}{l}\text { Quality } \\
\text { Teaching }\end{array}$ & 178 & 3 & 2.2 & 2 & 5 & 3.99 & .548 \\
\hline $\begin{array}{l}\text { Family } \\
\text { Involvement }\end{array}$ & 178 & 3 & 2.2 & 2 & 5 & 3.34 & .596 \\
\hline
\end{tabular}


Research Question 4: To what degree do cooperating teachers at different grade levels (elementary, middle, and high) have different perceptions of student teacher supervision as a professional development activity?

ANOVA was performed to discover the differences between cooperating teacher perceptions at different grade levels. Cooperating teaching as professional development, and the categories context, process, and content were the dependent variables and grade level was the independent variable. As presented in Table 25, the results indicated that there were no significant differences in cooperating teacher perceptions of professional development, or in context and content categories.

\section{Table 25}

Analysis of Variance for Grade Levels (Elementary, Middle and High)

\begin{tabular}{|c|c|c|c|c|c|c|}
\hline Source & & $\mathrm{SS}$ & $\mathrm{df}$ & MS & $\mathrm{F}$ & Sig. \\
\hline \multirow{3}{*}{$\begin{array}{l}\text { Professional } \\
\text { Development }\end{array}$} & Between Groups & .607 & 2 & .303 & 1.734 & .180 \\
\hline & Within Groups & 25.712 & 147 & .175 & & \\
\hline & Total & 26.319 & 149 & & & \\
\hline \multirow[t]{3}{*}{ Context } & Between Groups & .051 & 2 & .025 & .146 & .865 \\
\hline & Within Groups & 28.421 & 163 & .174 & & \\
\hline & Total & 28.472 & 165 & & & \\
\hline \multirow[t]{3}{*}{ Process } & Between Groups & 1.196 & 2 & .598 & 3.312 & $.039 *$ \\
\hline & Within Groups & 29.605 & 164 & .181 & & \\
\hline & Total & 30.801 & 166 & & & \\
\hline \multirow[t]{3}{*}{ Content } & Between Groups & .695 & 2 & .348 & 1.417 & .245 \\
\hline & Within Groups & 40.224 & 164 & .245 & & \\
\hline & Total & 40.919 & 166 & & & \\
\hline
\end{tabular}


There was a significant difference found in the process category. Post hoc comparisons using the Tukey HSD noted a significant difference was between elementary and high school teachers. Although elementary and middle school teachers had nearly identical scores (Table 26), significant differences were not found between high school and middle school. This may be attributed to the small size of the middle sample. In the process category, there were scores for 84 elementary teachers, 16 middle school teachers, and 67 high school teachers.

Table 26

Descriptive Statistics for Process Category by Grade Level (Elementary, Middle School and High School)

\begin{tabular}{|l|l|l|}
\hline Grades & $\mathrm{N}$ & $\mathrm{M}$ \\
\hline Elementary & 84 & 3.66 \\
\hline Middle & 16 & 3.68 \\
\hline High & 67 & 3.49 \\
\hline
\end{tabular}

Research Question 5: What is the relationship between cooperating teachers' experience levels (degree earned, years of full time teaching, and number of student teachers supervised) in their perceptions of student teacher supervision as a professional development activity?

Four multiple stepwise regression analyses were used to answer this question. The criterion variables were perceptions of cooperating teaching as professional development, and the context, process, and content categories of professional development. In this study, "experience" was defined by highest degree earned, years of full-time teaching, and the number of student teachers supervised. 
Each analysis determined that the number of supervised student teachers/experience supervising student teachers was the significant predictor of how cooperating teachers perceive this role as a professional development activity. This variable also significantly predicted how cooperating teachers view this role as using the context, process, and content standards of professional development. The coefficient of determination $\left(\mathrm{R}^{2}\right)$ indicated how much variance is accounted for by the independent variable. The coefficient of determination for professional development (.124), context (.102), process (.117), and content (.104) showed that experience with supervising student teachers accounted for $10 \%$ to $12 \%$ of how cooperating teaching is perceived. Table 27 shows the details of these analyses.

In stepwise multiple regression analysis, the relationship between the variables determines how each one is added or subtracted as predictors. Variables may be excluded as predictors if they are highly correlated with each other. Degree earned and years of teaching were the variables excluded in each analysis. The results of a bivariate correlation analysis may explain why the variable years of teaching was excluded. The number of supervised student teachers and the excluded variable years of teaching had a correlation of $.550(\mathrm{p}<.001)$. There is generally no rule regarding which relationship between variables is too high. However, researchers tend to agree that correlations greater than .8 present problems (Licht, 1995). 
Table 27

Summary of Stepwise Multiple Regression Analyses for Cooperating Teacher Experience

\begin{tabular}{lllllll}
\hline $\begin{array}{l}\text { NSDC Category } \\
\text { Predictor }\end{array}$ & B & Beta & $\mathbf{R}$ & $\mathbf{R}^{2}$ & $\begin{array}{c}\text { Model } \\
\text { Adjusted } \\
\mathbf{R}^{2}\end{array}$ & F \\
$\begin{array}{l}\text { Professional Development } \\
\text { Number of supervised } \\
\text { student teachers }\end{array}$ & .030 & .352 & .352 & .124 & .118 & $20.311^{*}$ \\
$\begin{array}{l}\text { Context Category } \\
\text { Number of supervised } \\
\text { student teachers }\end{array}$ & .028 & .319 & .319 & .102 & .096 & $18.017^{*}$ \\
$\begin{array}{l}\text { Process Category } \\
\text { Number of supervised } \\
\text { student teachers }\end{array}$ & .031 & .342 & .342 & .117 & .112 & $21.088^{*}$ \\
$\begin{array}{l}\text { Content Category } \\
\text { Number of supervised } \\
\text { student teachers }\end{array}$ & .034 & .322 & .322 & .104 & .100 & $18.250^{*}$ \\
\hline
\end{tabular}


Research Question 6: What is the relationship between cooperating teachers with different preparation (no training, informal meeting, student teacher orientation, mentorship training, or clinical faculty training) in their perceptions of student teacher supervision as a professional development activity?

This question was also addressed through four stepwise multiple regression analyses that the criterion variables perceptions of cooperating teaching as professional development, and the context, process, and content categories of professional development., Informal meeting, student teacher orientation, clinical faculty training, and mentorship training were the independent variables in each analysis. The results are listed in Table 28.

Each analysis showed negative beta weights for the predictor variables. This indicated that these predictors have a negative influence on how cooperating teaching is perceived. The analyses that used perceptions of cooperating teaching as professional development, and the process category as criterion variables had nearly identical results. Both results showed that mentorship training and clinical faculty training were negative predictors. Informal meeting and student teacher orientation meeting were the excluded variables in these analyses.

When context was the dependent variable, the results indicated that mentorship training was significant negative predictor of how the organizational supports of professional development are perceived. The coefficient of determination $\left(\mathrm{R}^{2}\right)$ equaled .105 , which indicated that variable explained $11 \%$ of the variance in the context category. The excluded variables of this analysis were clinical faculty training, mentorship training, informal meeting, and student orientation meeting. 
Clinical faculty training was the significant negative predictor when content was the criterion variable. Mentorship training, informal meetings, and student teacher orientation were the excluded variables.

Table 28

Summary of Stepwise Multiple Regression Analysis for Cooperating Teacher Preparation

\begin{tabular}{|c|c|c|c|c|c|c|}
\hline & & & & & Model & \\
\hline $\begin{array}{c}\text { NSDC Category } \\
\text { Predictor(s) }\end{array}$ & B & Beta & $\mathbf{R}$ & $\mathbf{R}^{2}$ & $\begin{array}{l}\text { Adjusted } \\
\qquad \mathbf{R}^{2}\end{array}$ & $\bar{F}$ \\
\hline $\begin{array}{l}\text { Professional } \\
\text { Development }\end{array}$ & & & .361 & .130 & .118 & $10.913^{*}$ \\
\hline $\begin{array}{l}\text { Mentorship training } \\
\text { Clinical faculty } \\
\text { training }\end{array}$ & $\begin{array}{l}-.203 \\
-.196\end{array}$ & $\begin{array}{l}-.235 \\
-.229\end{array}$ & & & & \\
\hline $\begin{array}{l}\text { Context Category } \\
\text { Mentorship training }\end{array}$ & -.275 & -.325 & .325 & .106 & .100 & $19.121^{*}$ \\
\hline $\begin{array}{l}\text { Process Category } \\
\text { Mentorship training } \\
\text { Clinical faculty } \\
\text { training }\end{array}$ & $\begin{array}{l}-.203 \\
-.182 \\
\end{array}$ & $\begin{array}{l}-.227 \\
-.206\end{array}$ & .335 & .113 & .102 & $10.334 *$ \\
\hline $\begin{array}{l}\text { Content Category } \\
\text { Clinical faculty } \\
\text { training }\end{array}$ & -.285 & -.280 & .280 & .079 & .073 & $13.998 *$ \\
\hline
\end{tabular}

Research Question 7: What demographic factors help predict how cooperating teachers perceive student teacher supervision as a professional development activity?

Stepwise multiple regression analyses were used to answer this question. In the first analysis, age, gender, and degree were the independent variables in each analysis. The analysis results for the criterion variables context, process, and perceptions of 
cooperating teaching as professional development showed that age was the significant negative predictor variable for each of these categories. The participants were asked to select age ranges from: $25-34,35-44,45-54$, and 55 plus. However, the coefficient of determination $\left(\mathrm{R}^{2}\right)$ shows that age accounts for only $3 \%$ to $4 \%$ of the variance. The analysis for the criterion variable, content, excluded all variables. These results are presented in Table 29.

Table 29

Summary of Stepwise Multiple Regression Analysis for Demographics

\begin{tabular}{|c|c|c|c|c|c|c|}
\hline & & & \multicolumn{4}{|c|}{ Model } \\
\hline $\begin{array}{l}\text { NSDC Standards } \\
\text { Predictor(s) }\end{array}$ & $\mathbf{B}$ & Beta & $\mathbf{R}$ & $\mathbf{R}^{2}$ & $\begin{array}{l}\text { Adjusted } \\
\mathbf{R}^{\mathbf{2}}\end{array}$ & $\mathbf{F}$ \\
\hline $\begin{array}{l}\text { Professional } \\
\text { Development }\end{array}$ & & & & & & \\
\hline Age & .074 & .179 & .179 & .032 & .025 & $4.738 *$ \\
\hline Context Category & & & & & & \\
\hline Age & .079 & .191 & .191 & .036 & .030 & $5.976 *$ \\
\hline $\begin{array}{l}\text { Process Category } \\
\text { Age }\end{array}$ & .068 & .157 & .157 & .025 & .018 & $4.002 *$ \\
\hline $\begin{array}{l}\text { Content Category } \\
\text { All variables excluded }\end{array}$ & - & - & - & - & - & - \\
\hline
\end{tabular}

In Table 30, stepwise multiple regression analysis was used to help determine if there were significant predictors using a different combination of independent variables: grade level, gender, highest degree, and currently has a student teacher. All of these variables were excluded in the analyses that used context, content, and perceptions of professional development as the criterion variables. In the analysis with the criterion 
variable of process, grade level was the significant negative predictor variable. However, the coefficient of determination $\left(\mathrm{R}^{2}\right)$ shows that it accounts for only $3 \%$ of the variance.

Table 30

Summary of Stepwise Multiple Regression Analysis for Demographics

\begin{tabular}{lllllll}
\hline Predictor(s) & B & Beta & $\mathrm{R}$ & $\mathrm{R}^{2}$ & $\begin{array}{c}\text { Adjusted } \\
\mathrm{R}^{2}\end{array}$ & $\mathrm{~F}$ \\
\hline Process Category & & & & & & \\
\hline Grade Level & -.078 & -.170 & .170 & .029 & .023 & $4.692^{*}$ \\
\hline
\end{tabular}

$* \mathrm{p}<.05$

The following research question was identified after the data collection. The researcher realized that comparing the perceptions clinical faculty teachers and cooperating teachers would add more depth and understanding to the data. Noted earlier, clinical faculty teachers represent $61 \%$ of the survey population and are cooperating teachers who have completed a graduate level course in supervision.

Research Question: To what degree do clinical faculty and cooperating teachers have different perceptions of student teacher supervision as a professional development activity?

As described in Table, 31, clinical faculty teachers had higher averages than cooperating teachers in all categories. ANOVA was used to determine if these averages were significantly different from each other. As displayed in Table 32, the ANOVA results indicated that clinical faculty teachers have significantly higher averages than cooperating teachers in the areas of process, content, and perceptions of cooperating teaching as professional development. However, the results did not indicate a significant 
difference in the context category. A t-test could have also been used for this analysis and yielded the same results.

Table 31

Descriptive Statistics of Clinical Faculty and Cooperating Teachers

\begin{tabular}{llccccc}
\hline & & $\mathrm{N}$ & Mean & Min. & Max & $\begin{array}{c}\text { Std. } \\
\text { Dev. }\end{array}$ \\
\hline $\begin{array}{l}\text { Professional } \\
\text { Development }\end{array}$ & Clinical Faculty & 88 & 3.80 & 3 & 5 & .379 \\
\hline & Cooperating Teachers & 63 & 3.56 & 2 & 5 & .441 \\
\hline Context & & & & & & \\
\hline & Clinical Faculty & 98 & 3.90 & 3 & 5 & .378 \\
\hline & Cooperating Teachers & 69 & 3.75 & 3 & 5 & .453 \\
\hline Process & & & & & & \\
\hline & Clinical Faculty & 100 & 3.69 & 3 & 5 & .396 \\
\hline & Cooperating Teachers & 68 & 3.47 & 2 & 5 & .455 \\
\hline Content & & & & & & \\
\hline & Clinical Faculty & 102 & 3.79 & 3 & 5 & .477 \\
\hline & Cooperating Teachers & 66 & 3.50 & 2 & 5 & .481 \\
\hline
\end{tabular}


Table 32

Analysis of Variance of Clinical Faculty and Cooperating Teachers

\begin{tabular}{|c|c|c|c|c|c|c|}
\hline Source & & SS & df & MS & $\mathbf{F}$ & Sig. \\
\hline \multirow[t]{3}{*}{$\begin{array}{l}\text { Professional } \\
\text { Development }\end{array}$} & $\begin{array}{l}\text { Between } \\
\text { Groups }\end{array}$ & 2.163 & 2 & 1.082 & 6.556 & $.002 *$ \\
\hline & $\begin{array}{l}\text { Within } \\
\text { Groups }\end{array}$ & 24.583 & 149 & .165 & & \\
\hline & Total & 26.746 & 151 & & & \\
\hline \multirow[t]{3}{*}{ Context } & $\begin{array}{l}\text { Between } \\
\text { Groups }\end{array}$ & .972 & 2 & .486 & 2.879 & .059 \\
\hline & $\begin{array}{l}\text { Within } \\
\text { Groups } \\
\end{array}$ & 27.867 & 165 & .169 & & \\
\hline & Total & 28.839 & 167 & & & \\
\hline \multirow[t]{3}{*}{ Process } & $\begin{array}{l}\text { Between } \\
\text { Groups }\end{array}$ & 2.034 & 2 & 1.017 & 5.751 & $.004 *$ \\
\hline & $\begin{array}{l}\text { Within } \\
\text { Groups } \\
\end{array}$ & 29.358 & 166 & .177 & & \\
\hline & Total & 31.393 & 168 & & & \\
\hline \multirow[t]{3}{*}{ Content } & $\begin{array}{l}\text { Between } \\
\text { Groups }\end{array}$ & 3.357 & 2 & 1.678 & 7.341 & $.001 *$ \\
\hline & $\begin{array}{l}\text { Within } \\
\text { Groups } \\
\end{array}$ & 37.952 & 166 & .229 & & \\
\hline & Total & 41.309 & 168 & & & \\
\hline
\end{tabular}


Chapter V: Summary, Discussion, and Recommendations

First, the reader will find a summary of the research findings and view there connection to this study's conceptual framework. The research findings will be discussed as they relate to the independent variables and to other studies on cooperating teaching. In closing, research implications and recommendations for future study will be addressed. Summary of Findings

This study examined cooperating teachers' perceptions on how student teacher supervision was aligned with the standards of the National Staff Development Council (NSDC). The participants completed a survey entitled Cooperating Teachers and Professional Development, which the researcher adapted from the Standards Assessment Inventory (SAI). The Cooperating Teacher and Professional Development Survey had 49 survey items that were intended to measure how serving as a cooperating teacher aligned with the NSDC standards. The SAI has 60 items intended to measure how a school's professional development aligned with the NSDC standards. The researcher did not convert 11 items from the SAI because they failed to measure an increase in teacher learning or measure a best practice of professional development as related to serving as a cooperating teacher.

The survey was completed by 181 out of the 287 sample population. Descriptive statistics and frequency counts were used to measure population demographics and analyzed how cooperating teaching aligned with the NSDC categories and standards. Analysis of variance (ANOVA) tests were used to show differences in group means and multiple regression analyses determined the significant predictor variables for determining cooperating teachers' perceptions. 
The findings are summarized as follows:

1. The survey's overall average showed that cooperating teachers moderately agreed that supervising student teachers was a professional development activity $(M=3.7)$. Cooperating teachers also moderately agreed that this role supported the context $(M=3.84)$, process $(M=3.60)$ and content $(M=3.67)$ needed for professional development. These averages were based on a one-to-five scale. Strongly disagree was equivalent to a 1 and a 5 equaled strongly agree. Distinct ranges were developed to classify these averages. Averages that fell within the range of 3.50-3.99 were classified as moderately agree.

2. ANOVA results showed that cooperating teachers at different grade levels had no significant differences in their perceptions of this role as a professional development activity. These results also showed no significant differences in the mean scores in the context and content professional development categories. However, elementary school teachers had significantly higher scores than high school teachers in process category of professional development. These differences were based on a post hoc comparisons using Tukey HSD. This finding should be noted with caution because the Tukey HSD did not reveal differences between high school and middle school teachers. Yet middle school $(\mathrm{M}=3.68)$ and elementary school teachers $(M=3.66)$ had nearly equivalent scores in the process category.

3. Clinical faculty teachers had higher perceptions of supervising student teachers as a professional development activity than non-clinical faculty teachers. These 
differences were significant in all categories except context. The results were based on a one way ANOVA.

4. Multiple regression analyses showed that the number of supervised student teachers or experience with student teachers was a significant predictor of how cooperating teachers perceive this role as a professional development activity. This independent variable also significantly predicted cooperating teachers' perceptions in the NSDC categories of context, process, and content.

5. Clinical faculty and mentorship training are the types of cooperating teacher preparations that negatively influence or predicts how cooperating teaching is viewed as a professional development activity. These types of training also negatively influence how this role uses the process standards. Mentorship training had a negative influence on cooperating teachers' perceptions in the context category and clinical faculty training was the negative predictor for the content category. These results were based on multiple regression analyses.

6. Based on multiple regression analysis, the participants' age was a demographic variable that positively predicted how cooperating teaching was viewed as a professional development activity.

\section{Discussion of Findings}

The discussion of these research findings will be linked to the conceptual framework of this study. The findings will be discussed in how they relate to cooperating teacher experience, preparation, and demographics. They will also be compared to other studies that have addressed the professional development benefits of cooperating teaching. 


\section{Conceptual Framework}

The conceptual framework of this study advanced that cooperating teaching is a professional development activity according to the NSDC standards. Professional development is an ongoing process that provides educators continuous improvements in their knowledge through activities that cause critical reflection. Individuals are engaged in issues related to school and student achievement. The best practices of professional development are represented in the NSDC standards. Professional development needs to be evaluated to reveal the strengths and weakness of a program or activity. The information generated from evaluations can help make improvements and/or judgments on the program's worth.

The roles and activities of cooperating teaching are related to mentoring, assessing, guiding, modeling, and coaching. They help student teachers transition into the world of education and are connected to instruction, content, curriculum and student achievement. These responsibilities can also translate into a professional development experience for the cooperating teacher. The participants in this study evaluated their experiences using a survey adapted from the NSDC.

The results of that survey, Cooperating Teacher and Professional Development, support this study's conceptual framework. Cooperating teachers moderately agreed that student teacher supervision is aligned with the categories of the NSDC: context, process, and content. This role had the contextual support structures for a professional development activity. This responsibility was supported by ongoing teams who meet regularly to discuss ways to improve student learning. Cooperating teachers have support from school administrators and their learning occurs during the school day. 
Serving as a cooperating teacher provided a process that supports how their learning activities are planned, organized, and carried out. This role provided opportunities for a teacher to use data for determining student learning needs and using various sources for guiding student improvements. This responsibility has helped increase an individual's collaborative skills and provided opportunities for interaction through reflection, observation, and dialogue. To a limited degree, being a cooperating teacher involved in a variety of learning strategies that included examining student work, coaching, and collaborating on designing lessons.

Being a cooperating teacher provided chances for an individual to develop content knowledge, a deeper understanding of an academic discipline, and chances for learning instructional approaches. This responsibility helped educators to refine their teaching skills and increased their professional knowledge. This role supported a person's ability to help meet the needs of diverse learners and to a limited degree helps supports them with family involvement. Cooperating teaching helped individuals learn assessment strategies and deepened their understanding of curriculum content.

\section{Cooperating Teacher Demographics and Experience}

The demographic variables of this survey were grade level, gender, highest degree earned, age, range, and current supervision of a student teacher. Based on these variables, cooperating teachers' age was a small but significant predictor in how they perceive their role as a professional development activity. Cooperating teachers with more life experience may appreciate and see the professional benefits of discovering and learning fresh and new ideas. Cooperating teacher preparation and experience have stronger predictor variables. 
In this study, cooperating teacher experience was defined by the variables of degree earned, years of full-time teaching, and the number of student teachers supervised. The number of supervised student teachers emerged as the predictor that determines how cooperating teachers view this role as a professional development activity and how this role incorporated the context, process, and content standards.

The variables of highest degree earned and years of full time teaching were excluded in all analyses. It should be noted that there was a moderate correlation between the variables years of full time teaching and number of supervised student teachers. Variables that are highly correlated with each other may exclude each other as predictors.

Highest degree earned and years of full-time teaching may have been excluded as experience variables because the word experience infers a by-product of practice or participation with something or someone. This inference may suggest that fulfilling the requirements of a degree or completing the duties of teaching is not the experience cooperating teachers need to see the benefits of this role.

Cooperating teachers benefit from supervising one student teacher. These findings also suggest that cooperating teachers continue to benefit from multiple interactions with different student teachers. This finding may be attributed to the individual differences among student teachers. Each student teacher brings different strengths and abilities that are incorporated in the cooperating teachers' practice. Other studies on cooperating teachers note how interactions with student teachers increase an individual's professional development. Working with student teachers validates the experiences teachers have gained over their teaching career (Koskela \& Ganser, 1995). Interacting with student 
teachers can cause cooperating teachers to pay more attention to their teaching practices and curriculum decisions (Landt, 2002).

\section{Cooperating Teacher Preparation}

A need exists for preparing cooperating teachers to supervise student teachers. Preparation helps cooperating teachers provide specific and objective feedback and can prevent them from having unrealistic student teacher expectations (Giebelhaus \& Bowman, 2002; Kent, 2001). Informal meeting(s) or conversation(s) with a college or university representative, student teacher orientation meeting (s), mentorship training, and clinical faculty training are methods of cooperating teacher preparation. The respondents were asked if they had participated any of the above activities.

Informal meetings and student orientation meetings briefly acquaint cooperating teachers with their roles and responsibilities in the teacher field experiences. They tend to just give an overview of who, what, when, where, and why of student teaching. Mentorship training provides strategies linked to coaching, assessing, and developing a positive rapport with the mentee. It can help cooperating teachers because it provides techniques on helping beginning teachers develop instructional planning and classroom management skills which can be used for student teachers.

Clinical faculty training is a graduate level supervision course offered by the university associated with this study that prepares experienced teachers for the roles and responsibilities of cooperating teaching. It can help them learn and apply mentoring strategies and skills and can positively increase the effects of their observation and conferencing skills. 
Preparation can help increase cooperating teachers' sense of efficacy because it helps them to realize that they are giving student teachers the best possible guidance. Preparation also leads to positive effects because of the support it provides (Borko \& Mayfield, 1995). An increased sense of efficacy can help individuals gain professional benefits of the activities that are involved in.

In contrast to the apparent benefits of cooperating teacher preparation, mentorship and clinical faculty training emerged as predictors that negatively affect how cooperating teaching is seen as a professional development activity. Because the survey did not request the specifics of the participants' mentorship training, it is difficult to determine why this variable emerged as a negative predictor in this study. However, this may have occurred because the participants perceive and associate mentorship training with helping beginning teachers. The participants may also view mentoring and mentorship training as a professional obligation that helps novice teachers transition to education.

In addition to the above information, we do know that the clinical faculty training associated with this university occurs during a two week period in the summer and is followed by four sessions throughout the school year. Clinical faculty teachers may feel that the training and collaboration with other clinical faculty teachers has a greater connection to their professional development than supervising student teachers. Experienced teachers do attend clinical faculty training as a precursor for their experience with student teachers. However, similar to mentoring, they may be more motivated as cooperating teachers due to their professional commitments rather than interest in their own professional development (Sinclair, 2006). 
Ramanthan and Wilkins-Canter (1997) comment that preparing cooperating teachers should be placed in the broader context of their professional development. This implies that cooperating teacher preparation, such as courses and workshops, should also be connected to developing the professional competencies of these experienced teachers. Preparation should help cooperating teachers understand their duties and increase their professional knowledge.

Cooperating Teachers Grade Level Assignment

Cooperating teachers in elementary school had significantly higher perceptions than high school teachers on how this role meets the process standards of professional development. Although these results are noted with caution, differences may be attributed to the different needs of the students and the different structure the school days. The process category is concerned with how learning activities are planned, organized, and carried out. The students and structure of an elementary school day require these teachers to provide more guidance and nurturing than high school teachers. The activities of an elementary school day may require more planning and organizing than high school. Due to these reasons, elementary cooperating teachers probably have more interactions with the student teacher on making data driven decisions and using activities that have collaborative lesson planning and coaching.

\section{Relating Findings from this Study to Other Research}

Studies that have addressed the professional development benefits gained from cooperating teaching tend to note the affective traits of why this role is a professional growth experience. They mention how cooperating teachers benefit from the student teachers' enthusiasm towards student learning (Kiraz, 2004; Koskela \& Ganser, 1995) 
and from seeing the student teachers' positive effect on the students (Gibbs \& Montoya, 1994). Supervising student teachers helps to reaffirm values and provides a broader connection to the world of education (Arnold, 2002). Being a cooperating teacher offers the professional satisfaction of seeing another person gain confidence in their teaching abilities (Ganser, 1997) and lessens teacher isolation (Holm, 2004; Landt, 2002).

This study sought to distinguish itself by viewing the role of cooperating teaching through the lens of the best practices of professional development as defined by the NSDC. To connect this study's findings to other studies on cooperating teaching and professional development, the researcher reviewed them using a content analysis approach. This approach was selected to connect the themes of these studies qualitative studies to findings to this quantitative study.

For the content analysis, the rationale statements of each NSDC standard served as the unit of analysis. They were written by the NSDC and provided a detailed description and examples on how the standards can be incorporated in a school. For example, these studies were examined for cooperating teachers' use of disaggregated data with the student teacher to help monitor student learning and determine learning priorities. This description is part of the data-driven standard.

Table 33 reveals the results of this analysis. These studies that address cooperating teacher and professional development were mentioned in a previous chapter of this document. Most of them noted characteristics of the quality teaching, learning, and learning communities' standards. A few studies noted characteristics of the equity and collaboration. The chart does show standards that were not readily addressed in these studies. These standards include leadership, evaluation and the family involvement 
standards. The standards that were not readily investigated could be topics of future research. Ideas for future research will be discussed in a later portion of this chapter.

Table 33

Cooperating Teacher Studies and their Alignment to the National Staff Development Council (NSDC) Standards

\begin{tabular}{|c|c|c|c|c|c|c|c|c|c|c|c|}
\hline 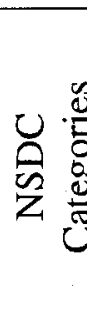 & $\begin{array}{c}\text { NSDC } \\
\text { Standards }\end{array}$ & 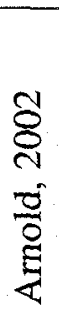 & 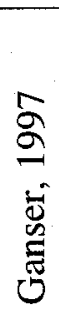 & 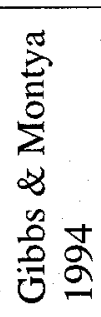 & 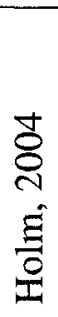 & 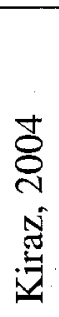 & 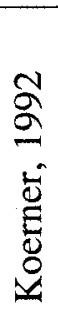 & 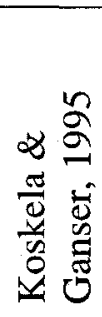 & 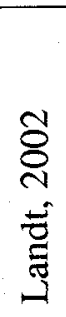 & 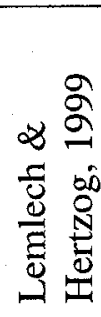 & 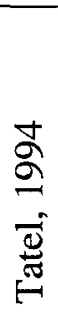 \\
\hline \multirow{3}{*}{ 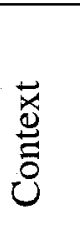 } & $\begin{array}{l}\text { Learning } \\
\text { Communities }\end{array}$ & 0 & 0 & & 0 & 0 & & & 0 & 0 & \\
\hline & Leadership & & & & & & & & & & \\
\hline & Resources & & & & & & & & & & \\
\hline \multirow{6}{*}{ 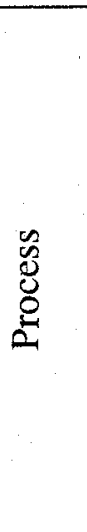 } & Data Driven & & & & & & & & & & \\
\hline & Evaluation & & & & & & & & & & \\
\hline & $\begin{array}{l}\text { Research- } \\
\text { based }\end{array}$ & & & & & & & & & & \\
\hline & $\begin{array}{l}\text { Design and } \\
\text { Strategies }\end{array}$ & & & & & & & & & & \\
\hline & Learning & 0 & 0 & 0 & 0 & 0 & 0 & 0 & O & 0 & \\
\hline & Collaboration & & & & & 0 & & & 0 & & \\
\hline \multirow{3}{*}{ 节 } & Equity & & & & & & & & & 0 & 0 \\
\hline & $\begin{array}{l}\text { Family } \\
\text { Involvement }\end{array}$ & & & & & & & & & & \\
\hline & $\begin{array}{l}\text { Quality } \\
\text { Teaching }\end{array}$ & 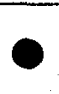 & & & & & & & & & \\
\hline
\end{tabular}

Table 33 shows the studies that have descriptors of the quality teaching standard.

Professional development that use this standard help educators learn a variety of 
assessment strategies. These activities can help educators incorporate research-based instructional strategies and increase their content knowledge and understanding. Being a cooperating teacher helps an individual learn assessment techniques (Tatel, 1994) and gain instructional techniques (Holm, 2004; Kiraz, 2004). The role provides a mechanism for making thoughtful and new changes in teaching practice (Koskela \& Ganser, 1995; Landt, 2002). Landt (2002) reports that supervising student teachers provides a connection to a university or college. This connection provides them the latest research on instructional strategies.

Characteristics of the learning standards are found in cooperating teacher research. Learning is a process standard that is connected to change and human learning. It recognizes that reflection on ideas or procedures moves educators to deeper understandings. Various studies on cooperating teachers discuss how this role increases their reflective abilities. Koerner (1992) comments that being a cooperating teaching promotes reflections as a self-practitioner and reflections on the teaching. It causes a person to examine him or herself as a professional and review how the classroom is organized.

Cooperating teacher research reports that student teacher observation is a mechanism for initiating reflection. It also helps teachers to discover things about their own students and teaching and creates a desire to question teaching strategies and approaches. Through observation, they notice classroom routines, witness student behavior, and gain more knowledge on how students interact with each other (Gibbs \& Montoya, 1994; Kiraz, 2004; Landt, 2002;Lemlech \& Hertzog, 1999). 
Studies on cooperating teachers have discussed components of the learning communities' standard. Learning communities organize ongoing teams that meet regularly to discuss school related issues. Cooperating teachers are provided frequent opportunities to work with another person and have ongoing conversations related to student learning, critiquing student work, and solving teaching concerns. This role lessens teacher isolation and provides an avenue for professional dialogue on teacher planning and classroom organization. (Arnold, 2002; Kiraz, 2004; Landt, 2002).

A limited number of research studies have related the equity standard to cooperating teaching. Equity is a content standard that prepares educators to have an appreciation for all students and have high expectations for student performance. It promotes understanding students' individual differences and knowing their cultural backgrounds. Cooperating teaching helps individuals to have a greater appreciation of students' needs and interests and helps promote beliefs of having positive expectations for student behavior and assignments (Lemlech \& Hertzog, 1999).

\section{Summary of Conclusions}

1. The results of this research imply that student teacher supervision is a professional growth opportunity for cooperating teachers and therefore should be considered an alternative form of professional development. Alternative forms of professional development engage educators in activities related to genuine problem solving and questions. They also connect a person to student learning, instruction, and content (Little, 1993). 
2. The results help school administrators see that this responsibility increases teacher learning. This demonstrates that student teachers are more than an extra set of hands for a classroom and school. Student teachers are a catalyst for increasing teacher knowledge and reflection.

3. In contrast to the apparent benefits of cooperating teacher preparation, mentorship and clinical faculty training are negative predictors for determining how this role is perceived as a professional development activity. Clinical faculty teachers may view the training has having more of an effect on their professional development than supervising student teachers.

4. Cooperating teachers benefit from multiple student teachers over a period of time. Each student teacher has a variety of strengths and attributes that are incorporated into the cooperating teachers' practice.

5. These results help schools of education at colleges and universities see that cooperating teachers receive professional development benefits from supervising student teachers.

\section{Areas of Further Attention}

Survey results indicated that serving as cooperating teachers used all of the standards of the NSDC. However, the family involvement $(M=3.34)$ and research-based $(M=3.13)$ standards had the lowest mean scores. Based on the range of 3.49 to 2.50 , these scores were in the neutral range. The following recommendations could be incorporated into the student teaching experience to help cooperating teachers better utilize these standards. 
1. Require that student teachers complete an action research project with cooperating teacher assistance. The research-based standard recommends that teachers investigate improvements in practice and the effectiveness of strategies through action research. Action research promotes continuous learning, problem solving and reflection. It helps teachers investigate their professional practices to help them make improvements and understand their work. Cooperating teacher and student teacher participation in action research helps answer and investigate questions that are personally and professionally beneficial to both parties (Levin \& Rock, 2003).

2. Require student teachers to create a plan to increase family involvement based on the specifics of the cooperating teachers' classroom. Creating an effective plan requires a knowing the cultural backgrounds and challenges of the students and their families. These potential action steps could list communication strategies and involve using technology as a communication tool. These components are part of the family involvement standard. This plan would be developed with the cooperating teachers' assistance.

\section{Future Research}

The purpose of this research was to see how student teacher supervision aligned with the NSDC standards. The results indicated support for each of these standards. Noted in an earlier section, studies have addressed components of the learning communities, quality teaching, and learning standards. Some studies have noted characteristics of the equity and collaboration standards. However, future research should 
involve more support and investigation on making deeper connections between serving as a cooperating teaching and the NSDC standards.

For example, research connecting the leadership standard to cooperating teaching could investigate, "How does your building administrator support your teacher learning as a cooperating teacher?" A component of the leadership standard supports developing the leadership abilities of educators. Another question could ask, "How does or how has this role increased your leadership skills and knowledge?

Another example could involve connecting clinical faculty training or supervision training to the collaboration skills standard. This standard recognizes the need for educators to learn the knowledge and skills needed for collaboration. Questions for consideration include, "What (if any) strategies gained through cooperating teacher training increased your ability to collaborate with your student teacher? "Did the collaborative skills gained through cooperating teaching assist you in other areas? If so, in what ways?

Future research also involves investigating if there is an ideal number of a supervised student teacher or ideal experience level with student teachers that creates the most professional development benefits for the teacher. This idea could extend to years of teaching experience. Is there an optimal number or range of teaching experience that helps an individual receives the most professional benefits of cooperating teaching? This could help schools of education in selecting or recruiting cooperating teachers. 


\section{References}

Abdal-Haqq, I. (1996). Making time for teacher professional development. Washington, D.C.: ERIC Clearinghouse on Teaching and Teacher Education.(ERIC Reproduction Service No. ED400259).

Arnold, P. (2002). Cooperating teachers' professional growth through supervision of student teachers and participation in a collegial study group. Teacher Education Quarterly, 29(2), 123-132.

Awaya, A., McEwan, H., Heyler, D., Linsky, S., Lum, D., and Wakukawa, P. (2003) Mentoring as a journey. Teaching and Teacher Education, 19, 45-56.

Ball, D. L., \& Cohen, D. K. (1999). Developing practice, developing practitioners: Toward a practice-based theory of professional education. In L. DarlingHammond \& G. Sykes (Eds.), Teaching as a learning profession: Handbook of policy and practice (pp. 3-32). San Francisco: Jossey-Bass, Inc.

Bellanca, J. (1995). Designing professional development for change. Palatine, IL: Skylight Publishing.

Boreen, J., Johnson, M. K., Niday, D., \& Potts, J. (2000). Mentoring beginning teachers: Guiding, reflecting, coaching. York, ME: Stenhouse Publishers.

Borich, G. (2000). Effective teaching methods (4th ed.). Upper Saddle River, NJ: Prentice-Hall, Inc.

Borko, H. \& Mayfield, V. (1995). The roles of the cooperating teacher and university supervisor in learning to teach. Teaching \& Teacher Education,11(5), 501-518.

Boudreau, P. (1999). The supervision of a student teacher as defined by cooperating teachers. Canadian Journal of Education, 24(4), 454-459. 
Bourque, L. B. \& Fielder, E. P. (2003). How to conduct self-administered and mail surveys ( $2^{\text {nd }}$ ed.). Newbury Park, CA: Sage Publications

Birman, B., Desimone, L., Porter, A., \& Garet, M. (2000) Designing professional development that works. Educational Leadership, 57 (8) 28-33.

Brown, B. L. (2002). Professional development for career educators. Columbus, $\mathrm{OH}$ : ERIC Clearinghouse on Adult Career and Vocational Education. (ERIC Reproduction No. ED472602).

Bryant, F. B. \& Yarnold, P. R. (2005). Principal-components analysis and exploratory and confirmatory factor analysis. In L. G. Grimm Yarnold (Eds.), Reading and understanding multivariate statistics. Washington, D. C.: American Psychological Association.

Caruso, J. J. (1998). What cooperating teacher case studies reveal about their phases of development as supervisors of student teachers. European Journal of Teacher Education, 21(1), 119-132.

Chalies, S., Ria, L., Bertone, S., Trohel, J., \& Durand, M. (2004). Interactions between preservice and cooperating teachers and knowledge construction during postlesson interviews. Teaching and Teacher Education, 20, 765-781.

Clarke, A. (2001). Characteristics of co-operating teachers. Canadian Journal of Education, 26(2), 237-256.

College of William and Mary (2005). Handbook for practica and student teaching experiences. Williamsburg, VA; Author.

Conner, K., Killmer, N., McKay, J., \& Whigham, M. (1993). Cooperating teacher effectiveness and training: Two views. Action in Teacher Education, 15(2), 72-78. 
Conner, K. R., \& Kilmer, N. (2001). Elementary and secondary cooperating teacher effectiveness: Is these a difference? (ERIC Document Reproduction Service No. ED461640). Chicago, IL: Mid-Western Educational Research Association.

Creswell, J. W. (2003). Research design: Qualitative, quantitative and mixed methods approaches (2nd ed.). Thousand Oaks, CA: Sage Publications.

Creswell, J. W. (2005). Educational research: Planning, conducting, and evaluating quantitative and qualitative research. Upper Saddle River, NJ: Pearson Education, Inc.

Darling-Hammond, L. \& McLaughlin, M. (1995). Policies that support professional development in an era of reform. Phi Delta Kappan, 76(8), 957-604.

Dever, M. T., Hager, K. D., \& Klein, K. (2003). Building the university/public school partnership: A workshop for mentor teachers. The Teacher Educator, 38(4), 245255.

Diaz-Maggioli, G. (2004). Teacher-centered professional development. Alexandra, VA: Association for Supervision and Curriculum Development.

Ediger, M. (1994). Problems in supervising student teachers. Education, 114(4), 628-631.

Elmore, R. F. (2002). Bridging the gap between standards and achievement: The imperative for professional development in education: Albert Shanker Institute Retrieved November 17, 2005, from http://www.shankerinstitute.org/Downloads/Bridging_Gap.pdf

Evertson, C. M., \& Smithey, M. W. (2000). Mentoring effects on proteges' classroom practice: An experimental field study. The Journal of Educational Research, 
93(5), 294-304.

Feiman-Nemser, S. (1990). Teacher preparation: Structural and conceptual alternatives. In Handbook of research on teacher education: A project of the association of teacher educators (pp. 212-233). New York: Macmillan Publishing Company.

Fowler, F. J. (2002). Survey research methods (3rd ed.). Thousand Oaks, CA: Sage Publications.

Fraenkel, J. R., \& Wallen, N. E. (2001). Educational research: A guide for the process. Mahwah, NJ: Lawrence Erbaum Associates.

Gall, M. D., Gall, J. P., \& Borg, W. R. (2003). Educational research: An introduction (7 ${ }^{\text {th }}$ ed.). Boston: Allyn and Bacon.

Gall, M. D., \& Vojtek, R. O. (1994). Planning for effective staff development: Six research based models. Eugene, OR: University of Oregon.

Ganser, T. (1996). The cooperating teacher role. Teacher Educator, 31, 283-191.

Ganser, T. (1997). The contribution of service as a cooperating teacher and mentor teacher to the professional development of teachers (ERIC Document Reproduction Service No. ED408279). Chicago, IL: American Educational Research Association.

Ganser, T. \&Wham, M. (1998). Voices of cooperating teachers: Professional contributions and personal satisfaction. Teacher Education Quarterly, 25, 43-53.

Ganser, T. (2002) How teachers compare the roles of cooperating teacher and mentor. The Educational Forum, 66(4), 45-51.

Garland, C., \& Shippy, V. (1995). Guiding clinical experiences: Effective supervision in teacher education. Norwood, NJ: Ablex Publishing Corporation. 
Gareis, C. R. (2005). Fighting the "rising tide" of the de-professionalization of teaching; The Clinical Faculty Program at the College of William and Mary. Annual Conference of the Consortium for Research in Education and Teacher Evaluation. Memphis, TN.

Garet, M. S., Porter, A. C., Desimone, L., Birman, B., \& Yoon, K. S. (2001). What makes professional development effective? Results from a national sample of teachers. American Educational Research Journal, 38(4), 915-945.

Gibbs, L. J., \& Montoya, A. L. (1994). The student teaching experience: Are student teachers the only ones to benefit? (ERIC Document Reproduction Service No. ED373025). Altanta, GA: Association of Teacher Educators.

Giebelhaus, C. R., \& Bowman, C. L. (2002). Teaching mentors: Is it worth the effort? The Journal of Educational Research, 95(4), 246-254.

Glickman, C. D., \& Bey, T. M. (1990). Supervision. In Handbook of research on teacher education: A project of the association of teacher educators (pp. 549-568). New York: MacMillan Publishing Company.

Glickman, C., Gordon, S., Ross-Gordon, J. (2001). Supervision and instructional leadership: A developmental approach (5 $5^{\text {th }}$ ed.). Boston: Allyn and Bacon. Guskey, T. R. (2000). Evaluating professional development. Thousand Oaks, CA: Corwin Press, Inc.

Guskey, T. R. (2002a). Does it make a difference? Evaluating professional development Educational Leadership, 59(6), 45-51.

Guskey, T. R. (2002b). Professional development and teacher change. Teachers and Teaching: Theory and Practice, 8(3/4), 381-391. 
Guskey, T. R. \& Sparks, D. (1991). What to consider when evaluating staff development. Educational Leadership. 49 (3), 73-76.

Guskey, T. R., \& Sparks, D. (2002). Linking professional development to improvements in student learning (ERIC Reproduction No. ED464112). New Orleans, LA: American Educational Research Association.

Guskey, T. R. (2003a). Professional development that works: What makes professional development effective? Phi Delta Kappan, 84(10), 748-750.

Guskey, T. R. (2003b). The characteristics of effective professional development: A synthesis of lists (ERIC Reproduction No. ED478380). Chicago, IL: American Educational Research Association.

Guyton, E., \& McIntyre, D. J. (1990). Student teaching and school experiences. In W. R. Houston (Ed.), Handbook of research on teacher education: A project of the association of teacher educators (pp. 514-534). New York: Macmillian Publishing Company.

Hawley, W. D., \& Valli, L. (1999). The essentials of effective professional development: A new consenus. In L. Darling-Hammond \& G. Sykes (Eds.), Teaching as a learning profession: Handbook of policy and practice (pp. 127-150). San Francisco: Jossey-Bass, Inc.

Hirsch, S. (2001). We're growing and changing. Journal of Staff Development, 22(3). Retrieved June 12, 2006, from http://nsdc.org/library/publications/jsd/hirsh223.pdf

Holm, M. S. (2004). Supervision of student teachers: A professional development experience for cooperating teachers. Dissertation Abstracts International 
$65,10 \mathrm{~A}$.

Hunt, G., Touzel, T., \& Wiseman D. (1999). Effective teaching: Preparation and implementation ( $3^{\text {rd }}$ ed.). Springfield, Il: Charles C. Thomas.

Janas, J. (1996). Mentoring the mentor: A challenge for staff development. Journal of Staff Development, 17(4).

Justen, J. E., McJunkin, M., \& Strickland, H. (1999). Supervisory beliefs of cooperating teachers. The Teacher Educator, 34(3), 173-180.

Kahn, B. (2001). Protrait of success: Cooperating teachers and the student teaching experience. Action in Teacher Education, 22(4), 48-58.

Kelleher, J. (2003). Professional development that works: A model for assessment-driven development. Phi Delta Kappan, 84(10), 751-756.

Kent, A. (2004). Improving teacher quality through professional development. Education, 124(3), 427-432.

Kent, K. I. (2001). Supervision of student teachers: Practices of cooperating teachers prepared in a clinical supervision course. Journal of Curriculum and Supervision, $16(3), 228-244$.

Kerka, S. (1996). Journal writing and adult learning. (ERIC Document Reproduction Service No. ED 399413). Columbus, OH: ERIC Clearinghouse on Adult Career and Vocational Education.

Kiraz, E. (2004). Unexpected impact of practicum: Experts learn from the novice. Teacher Education and Practice, 17(1), 71-88.

Kirkpatrick, D. L. (1996). Evaluating training programs: The four levels. San Francisco: Berrett-Koehlers Publishers. 
Koerner, M. E. (1992). The cooperating teacher: An ambivalent participant in student teaching. Journal of Teacher Education, 43(1), 46-56.

Korinek, L. A. (1989). Teacher preferences for training and compensation for field supervision. Journal of Teacher Education, 40, 46-51.

Kosela, R. \& Ganser, T. (1995) Exploring the role of cooperating teacher in relationship to personal career development. (ERIC Document Reproduction Service No. ED 3800445).

Landt, S. M. (2002). Cooperating teachers and professional development (ERIC Document Reproduction Service No. ED466799).

Lemlech, J. K., \& Hertzog, H. H. (1999). Reciprocal teaching and learning: What do master teachers and student teachers learn from each other? (ERIC Document Reproduction Service No. ED 429975). Montreal, Canada: American Educational Research Association.

Levin, B. B., \& Rock, T. C. (2003). The effects of collaborative action research on preservice and experienced teacher partners in professional development schools. Journal of Teacher Education, 54(2), 135-149

Licht, M. H. (2005). Multiple Regression and Correlation. In L. G. Grimm \& P. R. Yarnold (Eds.), Reading and understanding multivariate statistics. Washington, D.C.: American Psychological Association.

Little, J. W. (1993). Teachers' professional development in a climate of educational reform. Educational Evaluation and Policy Analysis. 15(2), 129-151.

Loucks-Horsley, S., Hewson, P. W., Love, N., \& Stiles, K. E. (1998). Designing professional development for teachers of science and mathematics. Thousand 
Oaks, CA: Corwin Press.

McEwan, E. K. (2002). Ten traits of highly effective teachers: How to hire, coach, and mentor successful teachers. Thousand Oaks, CA: Corwin Press, Inc.

McIntyre, D. J. \& Killian, J. E. (1987). The influence of supervisory training for cooperating teachers on preservice teachers' development during early field experiences. Journal of Educational Research, 80(51), 277-282.

Moir, E. (2005). Launching the Next Generation of Teachers: The New Teacher Center?

Model for Quality Induction and Mentoring. In H. Portner (Ed.). Teacher mentoring and induction: The state of the art and beyond. Thousand Oaks, CA: Corwin Press. Inc.

Morris, M., Chrispeels, J., \& Burke, P. (2003). Professional development that works: The power of two: Linking external and internal teacher's professional development. Phi Delta Kappan, 84(10), 764-767.

Murphy, J. (2005). Connecting teacher leadership and school improvement. Thousand Oaks, CA: Corwin Press.

National Staff Development Council (2001). Standards for staff development. Retrieved February 24, 2006 from www.nsdc.org/standards/index.cfm.

Osunde, E. O. (1996). The effect on student teachers of the teaching behaviors of cooperating teachers. Education, 116(4), 612-620.

Portner, H. (2003). Mentoring new teachers. Thousand Oaks, CA; Corwin Press. Ramanathan, R., \& Wilkins-Canter, E. (1997). Training for cooperating teachers and university supervisors in their role as evaluator in early field experiences (ERIC Document Reproduction Service No. ED414260). Chicago, IL: Mid-Western 
Educational Research Association.

Roy, P. (2004a). Move beyond workshops with NSDC standards. Results. National Staff

Development Council. Retrieved June 12, 2006, from

http://nsdc.org/library/publications/results/res9-04.cfm

Roy, P. (2004b). The three elements of the standards. Results. National Staff

Development Council. Retrieved June 12, 2006, from

http://nsdc.org/library/publications/results/res 11-04roy.cfm

Rudney, G. L., \& Guillaume, A. M. (2003). Maximum mentoring: An action guide for teacher trainers and cooperating teachers. Thousand Oaks, CA: Corwin Press, Inc.

Southwest Educational Development Laboratory (2003). National Staff Development Council Standards Assessment Inventory: Summary report of instrument development process and psychometric properties. Retrieved June 12, 2006, from http://www.sedl.org/es/samples/2003_NSDC_SumRpt.pdf.

Sparks, D., \& Hirsch, S. (1997). A new vision for staff development. Alexandria, VA: Association for Supervision and Curriculum Development.

Sparks, D., \& Hirsch, S. (2000). A national plan for improving professional development Retrieved March 30, 2006 from http://nsdc.org//hibrary/authors/NSDCPlan.cfm.

Sparks, D., \& Loucks-Horsley, S. (1989). Five models of staff development for teachers. Journal of Staff Development, 10(4), 35-51.

Speck, M., \& Knipe, C. (2001). Why can't we get it right? Professional development in our schools. Thousand Oaks, CA: Sage Publication.

Sudzina, M., Giebelhaus, C., \& Coolican, M. (1997). Mentor or tormentor: The role of 
the cooperating teacher in student teacher success or failure. Action in Teacher Education, 18(4), 23-35.

Stallings, J. A., \& Kowalski, T. (1990). Research on professional development schools. In W. R. Houston (Ed.), Handbook on research teacher education: A project of the association teacher educators (pp. 251-263). New York: MacMillian Publishing Company.

Tatel, E. S. (1994). Improving classroom practice: Ways experienced teachers change after supervising student teachers (ERIC Document Reproduction Service No. 372066). New Orleans, LA: American Educational Research Association.

Trubowitz, S. (2004). The why, how, and what of mentoring. Phi Delta Kappan, 86(1), 59.

Warden, J. E. (1986). Establishing partnerships between the business community and rural schools. (ERIC Document Reproduction Service No. ED287650). Las Cruces, NM: ERIC Clearinghouse on Rural Education and Small Schools

Weasmer, J., \& Woods, A. M. (2003). The role of the host teacher in the student teaching experience. The Clearing House, 76(4), 174-177.

Weinfurt, K. P. (2005). Multivariate analysis of variance. In L. G. Grimm \& P. R. Yarnold (Eds.), Reading and understanding multivariate statistics. Washington, D. C.: American Psychological Association.

Wilkins-Canter, E. A. (1997). The nature and effectiveness of feedback given by cooperating teachers to student teachers. Teacher Educator, 32(4), 235-249.

Woolley, S. L. (1997). What student teachers tell us (ERIC Document Reproduction Service No. ED430963). Washington, D. C.: Association of Teacher Educators. 
Yost, R. (2002). I think I can: Mentoring as a means of enhancing teacher efficacy.

Clearing House. 75(4), 195-97. 
Appendix A 
NSDC Category -Context

NSDC standard-- Learning Communities

\begin{tabular}{|c|c|c|c|}
\hline Original Item & Item intent & Modified Item & $\begin{array}{c}\text { Non- } \\
\text { converted }\end{array}$ \\
\hline $\begin{array}{l}\text { 9. The teachers in my school meet as a } \\
\text { whole staff to discuss ways to improve } \\
\text { teaching and learning. }\end{array}$ & $\begin{array}{l}\text { teachers meeting to discuss ways to } \\
\text { improve teaching and learning }\end{array}$ & $\begin{array}{l}\text { 9. The student teacher and I have met to } \\
\text { discuss ways to improve teaching and } \\
\text { learning. }\end{array}$ & \\
\hline $\begin{array}{l}\text { 29. We observe each other's classroom } \\
\text { instruction as one way to improve our } \\
\text { teaching. }\end{array}$ & $\begin{array}{l}\text { observing each other's classroom } \\
\text { instruction as one way to improve our } \\
\text { teaching. }\end{array}$ & $\begin{array}{l}29 . \text { Observing the student teachers' } \\
\text { instruction has been one way I have } \\
\text { improved my teaching. }\end{array}$ & \\
\hline $\begin{array}{l}\text { 32. Beginning teachers have } \\
\text { opportunities to work with more } \\
\text { experienced teachers at our school. }\end{array}$ & $\begin{array}{l}\text { do beginning teachers work with } \\
\text { experienced teachers at our school. }\end{array}$ & & $*$ \\
\hline $\begin{array}{l}\text { 34. We receive feedback from our } \\
\text { colleagues about classroom practices. }\end{array}$ & $\begin{array}{l}\text { receiving feedback from our } \\
\text { colleagues about classroom practices }\end{array}$ & $\begin{array}{l}\text { 34. I have received feedback from my } \\
\text { student teacher(s) about classroom } \\
\text { practices. }\end{array}$ & \\
\hline $\begin{array}{l}\text { 56. Teachers examine student work with } \\
\text { each other. }\end{array}$ & $\begin{array}{l}\text { teachers examining student work with } \\
\text { each other. }\end{array}$ & $\begin{array}{l}\text { 56. The student teacher and I have } \\
\text { examined student work with each other. }\end{array}$ & \\
\hline
\end{tabular}

\section{NSDC Category -Context}

NSDC standard-- Leadership

\begin{tabular}{|c|c|c|c|}
\hline Original Item & Item intent & Modified Item & $\begin{array}{c}\text { Non- } \\
\text { converted }\end{array}$ \\
\hline $\begin{array}{l}\text { 1. Our principal believes teacher learning } \\
\text { is essential for achieving our school } \\
\text { goals. }\end{array}$ & $\begin{array}{l}\text { principal beliefs' that teacher learning } \\
\text { is essential for achieving our school } \\
\text { goals }\end{array}$ & $\begin{array}{l}\text { 1. My principal believes that teacher } \\
\text { learning through cooperating teaching is } \\
\text { essential for achieving our school goals. }\end{array}$ & \\
\hline $\begin{array}{l}\text { 10. Our principal's decisions on school- } \\
\text { wide issues and practices are influenced } \\
\text { by faculty input. }\end{array}$ & $\begin{array}{l}\text { principal's decisions are influenced by } \\
\text { faculty input }\end{array}$ & & * \\
\hline $\begin{array}{l}\text { 18. Our principal is committed to } \\
\text { providing teachers with opportunities to } \\
\text { improve instruction (e.g. observations, }\end{array}$ & $\begin{array}{l}\text { principal's commitment in providing } \\
\text { teachers with opportunities to improve } \\
\text { instruction }\end{array}$ & $\begin{array}{l}\text { 18. My principal has been committed to } \\
\text { providing teachers opportunities to } \\
\text { improve instruction through the }\end{array}$ & \\
\hline
\end{tabular}




\begin{tabular}{|l|l|l|}
\hline feedback, collaborating with colleagues). & $\begin{array}{l}\text { supervision of student teachers (e.g. } \\
\text { observations, feedback, collaborating with } \\
\text { colleagues). }\end{array}$ \\
\hline $\begin{array}{l}\text { 45. Our principal fosters a school culture } \\
\text { that is focused on instructional } \\
\text { improvements. }\end{array}$ & $\begin{array}{l}\text { principal fostering a school culture } \\
\text { that is focused on instructional } \\
\text { improvements }\end{array}$ & $\begin{array}{l}\text { 45. My principal believes that supervising } \\
\text { student teachers fosters a school culture } \\
\text { that is focused on instructional } \\
\text { improvements. }\end{array}$ \\
\hline $\begin{array}{l}\text { 48. I would use the word, empowering, to } \\
\text { describe my principal. }\end{array}$ & $\begin{array}{l}\text { principal empowering teachers } \\
\text { to describe my principal's facilitation of } \\
\text { cooperating teaching. }\end{array}$ \\
\hline
\end{tabular}

\begin{tabular}{|c|c|c|c|}
\hline NSDC Category -Context & standard-- Resources & & \\
\hline Original Item & Item intent & Modified Item & $\begin{array}{c}\text { Non- } \\
\text { converted }\end{array}$ \\
\hline $\begin{array}{l}\text { 2. Fellow teachers, trainers, facilitators } \\
\text { and/or consultants are available to help us } \\
\text { implement new instructional practices at } \\
\text { our school. }\end{array}$ & $\begin{array}{l}\text { having help in implementing new } \\
\text { instructional practices at school }\end{array}$ & $\begin{array}{l}\text { 2. My student teacher(s) has been } \\
\text { available to help me implement new } \\
\text { instructional practices at our school. }\end{array}$ & \\
\hline $\begin{array}{l}\text { 11. Teachers at our school have } \\
\text { opportunities to learn how to use } \\
\text { technology to enhance instruction. }\end{array}$ & $\begin{array}{l}\text { having opportunities to learn how to } \\
\text { use technology to enhance instruction }\end{array}$ & $\begin{array}{l}\text { 11. Being a cooperating teacher has } \\
\text { provided me the opportunity to learn how } \\
\text { to use technology to enhance my } \\
\text { instruction. }\end{array}$ & \\
\hline $\begin{array}{l}\text { 19. Substitutes are available to cover our } \\
\text { classes when we observe each other's } \\
\text { classes or engage in other professional } \\
\text { development opportunities. }\end{array}$ & $\begin{array}{l}\text { using substitutes to cover our classes } \\
\text { when we observe each other }\end{array}$ & & $*$ \\
\hline $\begin{array}{l}\text { 35. In our school we find creative ways } \\
\text { to expand human and material resources. }\end{array}$ & $\begin{array}{l}\text { finding creative ways to expand } \\
\text { human and material resources. }\end{array}$ & $\begin{array}{l}\text { 35. Being a cooperating teacher has } \\
\text { helped me to find creative ways to expand } \\
\text { human and material resources. }\end{array}$ & \\
\hline $\begin{array}{l}\text { 49. School goals determine how } \\
\text { resources are allocated. }\end{array}$ & $\begin{array}{l}\text { determining if resources are allowed } \\
\text { due to school goals }\end{array}$ & $\begin{array}{l}\text { 49. School goals determine how } \\
\text { resources are allotted to support } \\
\text { cooperating teachers and student teachers. }\end{array}$ & \\
\hline
\end{tabular}


NSDC Category -Process

NSDC Standard--Data Driven

\begin{tabular}{|c|c|c|c|}
\hline Original Item & Item intent & Converted item & $\begin{array}{c}\text { Non- } \\
\text { converted } \\
\text { item }\end{array}$ \\
\hline $\begin{array}{l}\text { 12. Teachers at our school learn how to } \\
\text { use data to assess student learning } \\
\text { needs. }\end{array}$ & $\begin{array}{l}\text { learning how to use data to assess } \\
\text { student learning needs }\end{array}$ & $\begin{array}{l}\text { 12. Serving as a cooperating teacher, has } \\
\text { supported my ability to learn how to use } \\
\text { data to assess student learning needs. }\end{array}$ & \\
\hline $\begin{array}{l}\text { 26. Teachers at our school determine } \\
\text { the effectiveness of our professional } \\
\text { development by using data on student } \\
\text { improvement. }\end{array}$ & $\begin{array}{l}\text { using data on student improvement to } \\
\text { determine effectiveness of professional } \\
\text { development }\end{array}$ & & $*$ \\
\hline $\begin{array}{l}\text { 39. Teachers use student data to plan } \\
\text { professional development programs. }\end{array}$ & $\begin{array}{l}\text { use student data to plan professional } \\
\text { development programs }\end{array}$ & & $*$ \\
\hline $\begin{array}{l}\text { 46. Teachers use student data when } \\
\text { discussing instruction and curriculum. }\end{array}$ & $\begin{array}{l}\text { using student data when discussing } \\
\text { instruction and curriculum. }\end{array}$ & $\begin{array}{l}\text { 46. As a cooperating teacher, my student } \\
\text { teacher and I have used student data when } \\
\text { discussing instruction and curriculum. }\end{array}$ & \\
\hline $\begin{array}{l}\text { 50. Teachers analyze classroom data } \\
\text { with each other to improve student } \\
\text { learning. }\end{array}$ & $\begin{array}{l}\text { analyzing classroom data with each } \\
\text { other to improve student learning }\end{array}$ & $\begin{array}{l}\text { 50. As a cooperating teacher, my student } \\
\text { teacher and I analyze classroom data with } \\
\text { each other to improve student learning. }\end{array}$ & \\
\hline
\end{tabular}

\begin{tabular}{|c|c|c|c|}
\hline \multirow{2}{*}{$\begin{array}{l}\text { NSDC Category -Process } \\
\text { Original Item }\end{array}$} & C Standard & \multirow[b]{2}{*}{ Modified Item } & \\
\hline & Item intent & & $\begin{array}{l}\text { Non- } \\
\text { converted }\end{array}$ \\
\hline $\begin{array}{l}\text { 3. We design evaluations of our } \\
\text { professional development activities } \\
\text { prior to the professional development } \\
\text { program or set of activities. }\end{array}$ & $\begin{array}{l}\text { designing evaluations of our } \\
\text { professional development activities } \\
\text { prior to the professional development }\end{array}$ & $\begin{array}{l}\text { 3. I have evaluated what I would like to } \\
\text { gain from this experience prior to the } \\
\text { student teacher(s) arrival. }\end{array}$ & \\
\hline $\begin{array}{l}\text { 13. We use several sources to evaluate } \\
\text { the effectiveness of our professional } \\
\text { development on student learning (e.g. }\end{array}$ & $\begin{array}{l}\text { evaluating the effectiveness of our } \\
\text { professional development on student } \\
\text { learning }\end{array}$ & $\begin{array}{l}\text { 13. As a cooperating teacher, I have used } \\
\text { several sources to evaluate the } \\
\text { effectiveness of this experience on student }\end{array}$ & \\
\hline
\end{tabular}




\begin{tabular}{|c|c|c|c|}
\hline $\begin{array}{l}\text { classroom observation, teacher surveys, } \\
\text { conversations with principals or } \\
\text { coaches). }\end{array}$ & & $\begin{array}{l}\text { learning (e.g. classroom observation, } \\
\text { teacher surveys, conversations with } \\
\text { principals or coaches). }\end{array}$ & \\
\hline $\begin{array}{l}\text { 20. We set aside time to discuss what } \\
\text { we learned from our professional } \\
\text { development experiences. }\end{array}$ & $\begin{array}{l}\text { setting aside time to discuss what was } \\
\text { learned from the professional } \\
\text { development experiences. }\end{array}$ & $\begin{array}{l}\text { 20. My student teacher and I have set } \\
\text { aside time to discuss what I have learned } \\
\text { from this professional development } \\
\text { experience. }\end{array}$ & \\
\hline $\begin{array}{l}\text { 30. At our school, evaluations of } \\
\text { professional development outcomes are } \\
\text { used to plan for professional } \\
\text { development choices. }\end{array}$ & $\begin{array}{l}\text { evaluating professional development to } \\
\text { plan for other professional choices. }\end{array}$ & $\begin{array}{l}\text { 30. Evaluating the outcomes of my } \\
\text { experiences as a cooperating teacher has } \\
\text { helped me to plan for other professional } \\
\text { choices. }\end{array}$ & \\
\hline $\begin{array}{l}\text { 51. We use students' classroom } \\
\text { performance to assess the success of } \\
\text { teachers' professional development } \\
\text { experiences. }\end{array}$ & $\begin{array}{l}\text { using students' classroom performance } \\
\text { to assess the success of teachers' } \\
\text { professional development experiences }\end{array}$ & & * \\
\hline
\end{tabular}

NSDC Category-Process
\begin{tabular}{|l|l|l|l|}
\hline Original Item & $\begin{array}{l}\text { Non- } \\
\text { converted }\end{array}$ \\
\hline $\begin{array}{l}\text { 4. Our school uses educational research } \\
\text { to select programs. }\end{array}$ & $\begin{array}{l}\text { using educational research to select } \\
\text { programs }\end{array}$ & $\begin{array}{l}\text { 4. As a cooperating teacher I have used } \\
\text { educational research to select programs. }\end{array}$ & $\begin{array}{l}\text { 14. I made the decision to participate as a } \\
\text { cooperating teacher based on research that } \\
\text { shows evidence of improved student } \\
\text { performance. }\end{array}$ \\
\hline $\begin{array}{l}\text { 14. We make decisions about } \\
\text { professional development based on } \\
\text { research that shows evidence of } \\
\text { improved student performance. } \\
\text { development based on student } \\
\text { performance }\end{array}$ & $\begin{array}{l}\text { looking at evidence of effective school } \\
\text { programs before adapting them }\end{array}$ & $*$ \\
\hline $\begin{array}{l}\text { improvements efforts to adapt, we look } \\
\text { at evidence of effectiveness of } \\
\text { programs in other schools. }\end{array}$ & $\begin{array}{l}\text { 36. When considering school } \\
\text { improvements programs we ask } \\
\text { whether the program has resulted in } \\
\text { student achievement gains. }\end{array}$ & $\begin{array}{l}\text { asking whether the program has resulted } \\
\text { in student achievement gains }\end{array}$ & $\begin{array}{l}\text { 36. When I considered being a } \\
\text { cooperating teacher I asked if this } \\
\text { experience has resulted in student } \\
\text { achievement gains. }\end{array}$ \\
\hline
\end{tabular}




\begin{tabular}{|l|l|l|l|}
\hline $\begin{array}{l}\text { 41. The school improvement programs } \\
\text { we adopt have been effective with } \\
\text { student populations similar to ours. }\end{array}$ & $\begin{array}{l}\text { adopting school programs that are } \\
\text { effective with similar student } \\
\text { populations }\end{array}$ & $*$ \\
\hline
\end{tabular}

\section{NSDC Category - Process NSDC Standard- Design and Strategies}

\begin{tabular}{|c|c|c|c|}
\hline Original Item & Item Intent & Converted Item & $\begin{array}{c}\text { Non- } \\
\text { converted }\end{array}$ \\
\hline $\begin{array}{l}\text { 15. At our school teacher learning is } \\
\text { supported through a combination of } \\
\text { strategies (e.g. workshops, peer } \\
\text { coaching, study groups, joint planning } \\
\text { of lessons, and examination of student } \\
\text { work) }\end{array}$ & $\begin{array}{l}\text { supporting teacher learning through a } \\
\text { combination of strategies }\end{array}$ & $\begin{array}{l}\text { 15. As a cooperating teacher, my learning } \\
\text { has been supported through a combination } \\
\text { of strategies (e.g. workshops, peer } \\
\text { coaching, study groups, joint planning of } \\
\text { lessons, and examination of student } \\
\text { work). }\end{array}$ & \\
\hline $\begin{array}{l}\text { 22. We design improvement strategies } \\
\text { based on clearly stated outcomes for } \\
\text { teacher and student learning. }\end{array}$ & $\begin{array}{l}\text { designing improvement strategies based } \\
\text { on clearly stated outcomes for teacher } \\
\text { and student learning }\end{array}$ & $\begin{array}{l}22 . \text { Serving as a cooperating teacher at my } \\
\text { school is a designed improvement strategy } \\
\text { based on clearly stated outcomes for } \\
\text { teacher learning. }\end{array}$ & \\
\hline $\begin{array}{l}\text { 38. Teacher professional development } \\
\text { is part of our school improvement plan. }\end{array}$ & $\begin{array}{l}\text { measuring if teaching professional } \\
\text { development is part of the school's } \\
\text { improvement plan }\end{array}$ & $\begin{array}{l}\text { 38. Teacher professional development } \\
\text { including serving as a cooperating teacher } \\
\text { is part of our school's improvement plan. }\end{array}$ & \\
\hline $\begin{array}{l}\text { 52. Teachers' prior knowledge and } \\
\text { experience are taken into consideration } \\
\text { when designing staff development at } \\
\text { our school. }\end{array}$ & $\begin{array}{l}\text { using teacher prior knowledge and } \\
\text { experience to design staff development }\end{array}$ & $\begin{array}{l}\text { 52. My prior knowledge and experience } \\
\text { has been taken into consideration when } \\
\text { designing my learning opportunities with } \\
\text { the student teacher }\end{array}$ & \\
\hline $\begin{array}{l}\text { 57. When we adopt school } \\
\text { improvement initiatives we stay with } \\
\text { them long enough to see if changes in } \\
\text { instructional practice and student } \\
\text { performance occur. }\end{array}$ & $\begin{array}{l}\text { seeing if adopted initiatives change } \\
\text { instructional practices and student } \\
\text { performance over time. }\end{array}$ & $\begin{array}{l}\text { 57. At my school, we have adopted } \\
\text { serving as a cooperating teacher as an } \\
\text { option for teachers long enough to see if } \\
\text { changes in instructional practice and } \\
\text { student performance occur. }\end{array}$ & \\
\hline
\end{tabular}


NSDC Category-Process

NSDC Standard- Learning

\begin{tabular}{|c|c|c|c|}
\hline Original Item & Item intent & Converted Item & $\begin{array}{c}\text { Non } \\
\text { Converted }\end{array}$ \\
\hline $\begin{array}{l}\text { 5. We have } \\
\text { opportunities to practice } \\
\text { new skills gained during } \\
\text { staff development }\end{array}$ & $\begin{array}{l}\text { having opportunities to practice new skills } \\
\text { gained during staff development }\end{array}$ & $\begin{array}{l}\text { 5. As a cooperating teacher I have had } \\
\text { opportunities to practice the new skills that I have } \\
\text { gained through this experience. }\end{array}$ & \\
\hline $\begin{array}{l}\text { 16. We receive support } \\
\text { implementing new skills } \\
\text { until they become a } \\
\text { natural part of } \\
\text { instruction. }\end{array}$ & $\begin{array}{l}\text { receiving support with implementing new skills } \\
\text { until they become a natural part of instruction. }\end{array}$ & $\begin{array}{l}\text { 16. As a cooperating teacher, I have received } \\
\text { support implementing new skills until they } \\
\text { become a natural part of instruction. }\end{array}$ & \\
\hline $\begin{array}{l}\text { 27. Our professional } \\
\text { development promotes } \\
\text { deep understanding of a } \\
\text { topic. }\end{array}$ & promoting deep understanding of a topic. & $\begin{array}{l}\text { 27. Being a cooperating teacher, has promoted a } \\
\text { deeper understanding of a topic I teach. }\end{array}$ & \\
\hline $\begin{array}{l}\text { 42. At my school, } \\
\text { teachers learn through a } \\
\text { variety of methods (e.g. } \\
\text { hands-on activities, } \\
\text { discussion, dialogue, } \\
\text { writing, demonstrations } \\
\text { practice with feedback, } \\
\text { group problem solving). }\end{array}$ & learning through a variety of methods & $\begin{array}{l}\text { 42. As a cooperating teacher, I have learned } \\
\text { through a variety of methods (e.g. hands-on } \\
\text { activities, discussion, dialogue, writing, } \\
\text { demonstrations practice with feedback, group } \\
\text { problem solving). }\end{array}$ & \\
\hline $\begin{array}{l}\text { 53. At our school, } \\
\text { teachers can choose the } \\
\text { type of professional } \\
\text { development they } \\
\text { receive (e.g., study } \\
\text { group, action research, } \\
\text { observation). }\end{array}$ & $\begin{array}{l}\text { choosing the type of professional development } \\
\text { teachers receive }\end{array}$ & $\begin{array}{l}\text { 53. Being a cooperating teacher is one of the } \\
\text { many types of professional development } \\
\text { opportunities (e.g., study group, action research, } \\
\text { observation) that I can choose from. }\end{array}$ & \\
\hline
\end{tabular}


NSDC Category-Process

NSDC Standard-Collaboration

\begin{tabular}{|c|c|c|c|}
\hline Original Item & & Converted item & $\begin{array}{c}\text { Non- } \\
\text { converted }\end{array}$ \\
\hline $\begin{array}{l}\text { 6. Our faculty learns } \\
\text { about effective ways to } \\
\text { work together. }\end{array}$ & learning effective ways to work together & $\begin{array}{l}\text { 6. Being a cooperating teacher has helped me to } \\
\text { learn effective ways to work with others. }\end{array}$ & \\
\hline $\begin{array}{l}\text { 23. My school structures } \\
\text { time for teachers to } \\
\text { work together to } \\
\text { enhance student } \\
\text { learning. }\end{array}$ & $\begin{array}{l}\text { Structuring time to work together to enhance } \\
\text { student learning. }\end{array}$ & $\begin{array}{l}\text { 23. My school structures time for cooperating } \\
\text { teachers to work with other teachers to enhance } \\
\text { student learning. }\end{array}$ & \\
\hline $\begin{array}{l}28 . \text { Our school's } \\
\text { teaching and learning } \\
\text { goals depend on staff's } \\
\text { ability to work well } \\
\text { together. }\end{array}$ & $\begin{array}{l}\text { teaching and learning dependent on working } \\
\text { well with staff together }\end{array}$ & $\begin{array}{l}\text { 28. My teaching and learning as a cooperating } \\
\text { teacher has been dependent on how well the } \\
\text { student teacher and I work together. }\end{array}$ & \\
\hline $\begin{array}{l}\text { 43. Our school leaders } \\
\text { encourage sharing } \\
\text { responsibility to achieve } \\
\text { school goals. }\end{array}$ & $\begin{array}{l}\text { encouraging the sharing of the responsibility to } \\
\text { achieve school goals }\end{array}$ & $\begin{array}{l}\text { 43. Being a cooperating teacher has encouraged } \\
\text { me to share the responsibility of achieving school } \\
\text { goals. }\end{array}$ & \\
\hline $\begin{array}{l}\text { 58. Our principal models } \\
\text { effective collaboration. }\end{array}$ & modeling effective collaboration & & $*$ \\
\hline
\end{tabular}

NSDC Category-- Content NSDC standard-- Equity

\begin{tabular}{|l|l|l|l|}
\hline Original Item & Item intent & Modified Item & $\begin{array}{l}\text { Non- } \\
\text { Converted }\end{array}$ \\
\hline $\begin{array}{l}\text { 24. At our school, we } \\
\text { adjust instruction and } \\
\text { assessment to meet the } \\
\text { needs of diverse } \\
\text { learners. }\end{array}$ & $\begin{array}{l}\text { adjusting instruction and assessment to meet the } \\
\text { needs of diverse learners }\end{array}$ & $\begin{array}{l}\text { 24. Being a cooperating teacher has helped me to } \\
\text { adjust instruction and assessment to meet the } \\
\text { needs of diverse learners. }\end{array}$ & \\
\hline
\end{tabular}




\begin{tabular}{|c|c|c|}
\hline $\begin{array}{l}\text { 33. Teachers show } \\
\text { respect for all of the } \\
\text { student subpopulations } \\
\text { in our school (e.g. poor, } \\
\text { minority) }\end{array}$ & $\begin{array}{l}\text { showing respect for all of the student } \\
\text { subpopulations in our school }\end{array}$ & $\begin{array}{l}\text { 33. Serving as a cooperating teacher has helped } \\
\text { me to show respect for all of the student } \\
\text { subpopulations in our school (e.g. poor, } \\
\text { minority). }\end{array}$ \\
\hline $\begin{array}{l}\text { 37. Teachers at our } \\
\text { school expect high } \\
\text { academic achievement } \\
\text { for all of our students. }\end{array}$ & $\begin{array}{l}\text { expecting high academic achievement for all of } \\
\text { our students }\end{array}$ & $\begin{array}{l}\text { 37. Being a cooperating teacher has supported my } \\
\text { expectations of high academic achievement for } \\
\text { all of our students. }\end{array}$ \\
\hline $\begin{array}{l}\text { 44. We are focused on } \\
\text { creating positive } \\
\text { relationships between } \\
\text { teachers and students. }\end{array}$ & $\begin{array}{l}\text { focusing on creating positive relationships } \\
\text { between teachers and students }\end{array}$ & $\begin{array}{l}\text { 44. Serving as a cooperating teacher has } \\
\text { increased my focus on creating positive } \\
\text { relationships with my students. }\end{array}$ \\
\hline $\begin{array}{l}\text { 59. Teachers receive } \\
\text { training on curriculum } \\
\text { and instruction for } \\
\text { students at different } \\
\text { levels of learning. }\end{array}$ & $\begin{array}{l}\text { receiving training on curriculum and instruction } \\
\text { for students at different levels of learning }\end{array}$ & $\begin{array}{l}\text { 59. Being a cooperating teacher has supported my } \\
\text { training on curriculum and instruction for } \\
\text { students at different levels of learning. }\end{array}$ \\
\hline
\end{tabular}

NSDC Category-- Content

NSDC standard-- Quality Teaching

\begin{tabular}{|l|l|l|l|}
\hline Original Item & Item intent & $\begin{array}{c}\text { Non- } \\
\text { converted }\end{array}$ \\
\hline $\begin{array}{l}\text { 7. Teachers are provided } \\
\text { opportunities to learn } \\
\text { how to involve families } \\
\text { in their children's } \\
\text { education. }\end{array}$ & $\begin{array}{l}\text { providing opportunities to learn how to involve } \\
\text { families in their children's education }\end{array}$ & $\begin{array}{l}\text { 7. Being a cooperating teacher has provided me } \\
\text { the opportunities to learn how to involve families } \\
\text { in their children's education. }\end{array}$ & \\
\hline $\begin{array}{l}\text { 17. The professional } \\
\text { development that I } \\
\text { participate in models } \\
\text { instructional strategies } \\
\text { that I will use in my }\end{array}$ & $\begin{array}{l}\text { participating in professional development that } \\
\text { models the instructional strategies that I will } \\
\text { use in my classroom }\end{array}$ & $\begin{array}{l}\text { 17. The professional development of cooperating } \\
\text { teaching has provided me models of instructional } \\
\text { strategies that I can use in my classroom. }\end{array}$ & \\
\hline
\end{tabular}




\begin{tabular}{|c|c|c|}
\hline classroom. & & \\
\hline $\begin{array}{l}25 \text {. We use research- } \\
\text { based instructional } \\
\text { strategies. }\end{array}$ & using research-based instructional strategies. & $\begin{array}{l}\text { 25. As a cooperating teacher, I have used } \\
\text { research-based instructional strategies. }\end{array}$ \\
\hline $\begin{array}{l}\text { 54. Our school's } \\
\text { professional } \\
\text { development helps me } \\
\text { learn about effective } \\
\text { student assessment } \\
\text { techniques. }\end{array}$ & $\begin{array}{l}\text { learning about effective student assessment } \\
\text { techniques. }\end{array}$ & $\begin{array}{l}\text { 54. The professional development of cooperating } \\
\text { teaching has helped me learn about effective } \\
\text { student assessment techniques. }\end{array}$ \\
\hline $\begin{array}{l}60 . \text { Our administrators } \\
\text { engage teachers in } \\
\text { conversations about } \\
\text { instruction and student } \\
\text { learning. }\end{array}$ & $\begin{array}{l}\text { engaging in conversations about instruction and } \\
\text { student learning }\end{array}$ & $\begin{array}{l}\text { 60. The student teacher(s) and I have been } \\
\text { engaged in conversations about instruction and } \\
\text { student learning. }\end{array}$ \\
\hline
\end{tabular}

NSDC Category Content

\begin{tabular}{|l|l|l|c|}
\hline Original Item & $\begin{array}{c}\text { Ntem intent } \\
\text { Non- } \\
\text { converted }\end{array}$ \\
\hline $\begin{array}{l}\text { 8. Teachers are provided } \\
\text { opportunities to learn } \\
\text { how to involve families } \\
\text { in their children's } \\
\text { education. }\end{array}$ & $\begin{array}{l}\text { providing opportunities to learn how to involve } \\
\text { families in their children's education. }\end{array}$ & $\begin{array}{l}\text { 8. Being a cooperating teacher has provided me } \\
\text { the opportunity to learn how to involve families } \\
\text { in their children's education. }\end{array}$ & \\
\hline $\begin{array}{l}\text { 31.Communicating our } \\
\text { school mission and goals } \\
\text { to families and } \\
\text { community members is } \\
\text { a priority. }\end{array}$ & $\begin{array}{l}\text { communicating to families about school } \\
\text { mission and goals }\end{array}$ & & $*$ \\
\hline $\begin{array}{l}\text { 40. School leaders work } \\
\text { with community } \\
\text { members to help student } \\
\text { achieve academic goals. }\end{array}$ & $\begin{array}{l}\text { working to achieve academic goals with school } \\
\text { leaders }\end{array}$ & & $*$ \\
\hline
\end{tabular}




\begin{tabular}{|c|c|c|}
\hline $\begin{array}{l}\text { 47. Our principal models } \\
\text { how to build } \\
\text { relationships with } \\
\text { students' families. }\end{array}$ & $\begin{array}{l}\text { principal modeling how to building } \\
\text { relationships with student's families }\end{array}$ & $\begin{array}{l}\text { 47. As a cooperating teacher, I have modeled how } \\
\text { to build relationships with students' families. }\end{array}$ \\
\hline $\begin{array}{l}\text { 55. Teachers work with } \\
\text { families to help them } \\
\text { support students' } \\
\text { learning at home. }\end{array}$ & $\begin{array}{l}\text { working with families to help them support } \\
\text { students' learning at home }\end{array}$ & $\begin{array}{l}\text { 55. Being a cooperating teacher has helped me to } \\
\text { work with families to support students' learning } \\
\text { at home. }\end{array}$ \\
\hline
\end{tabular}


Appendix B 


\section{Cooperating Teachers and Professional Development}

Section One - Part A: Please complete the following statements that best describe you. This information will help with the data analysis.
Grade level:
Elementary K-5
Middle School 6-8
High School 9-12
Gender:
Female
Male
Ethnicity:
African-American
Asian
Caucasian
Hispanic
Other
Age:
O $25-34$
O $35-44$
O $45-54$
$55+$

\section{Highest \\ degree:}
Years of full-
time teaching:

\section{BA or BS}
$\mathrm{MA}$ or MS
MA/MS + 30
Od.S
Ed.D/Ph.D

Section One - Part B: Please answer the following questions.

Do you have a student teacher this school year? Yes No

In your teaching career, how many student teachers have you supervised?

(include William and Mary and students from other colleges and universities)

Have you participated in any of the following types of training to prepare you for serving as a cooperating teacher? Read each statement and check the appropriate box.

\begin{tabular}{|l|l|l|}
\hline $\begin{array}{l}\text { Informal meeting(s) or conversation(s) with a college or university } \\
\text { representative }\end{array}$ & Yes & No \\
\hline Student teacher orientation meeting(s) by a college or university & & \\
\hline Student teacher orientation meeting(s) by a school division & & \\
\hline Clinical faculty training by the College of William and Mary & & \\
\hline Clinical faculty training by another college or university & & \\
\hline Training on how to mentor new teachers, provided by a school division & & \\
\hline Other & & \\
\hline
\end{tabular}


Directions: Based on your cumulative experience of serving as a cooperating teacher, please circle the answer that best reflects your opinion for each statement. (This survey was adapted from the NSDC Standards Assessment Inventory and is used with permission.)

\section{Scale}

$\mathrm{SD}=$ Strongly Disagree $\quad \mathrm{D}=$ Disagree $\quad \mathrm{N}=$ Neutral $\quad \mathrm{A}=$ Agree $\quad \mathrm{SA}=$ Strongly Agree

\section{My principal believes that teacher learning through cooperating teaching is essential for achieving our school goals.}

2. My student teacher(s) has helped me think about implementing new instructional practices at our school. 3. Thave evaluated what I would like to gain from this experience prior to the student teacher(s) arrival

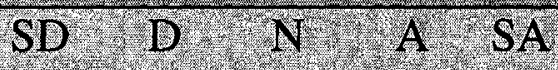
4. As a cooperating teacher I have used educational research to select school programs.

5. As a cooperating teacher I have had opportunities to practice the new skills that I have gained through this experience.

6. Being a cooperating teacher has helped me to learn effective ways to work with others

7. Being a cooperating teacher has provided me the opportunity to gain a deeper understanding of the subjects I teach

8. Being a cooperating teacher has provided me the opportunity to learn how to involve families in their children's education.

9. The student teacher ( $s$ ) and I have met regularly to discuss ways to improve teaching and learning

SD $\quad$ D $\quad N \quad$ A $\quad$ SA 10. Being a cooperating teacher has provided me the opportunity to learn how to use technology to enhance my instruction.

11. Serving as a cooperating teacher, has supported iny ability to learn how to use data to assess student learning needs.

12. As a cooperating teacher, I have used several sources to evaluate the effectiveness of this experience on student learning (e.g. classroom observation, teacher surveys, conversations with principals or coaches).

13. One criterion that I considered in my decision to participate as a cooperating teacher was based on research that shows evidence of improved student performance. 14. As a cooperating teacher, my learning has been supported through a combination of strategies (e.g. SD $D=N=A-S A$ $\mathrm{SD} \quad \mathrm{D} \quad \mathrm{N} \quad \mathrm{A}$ SA

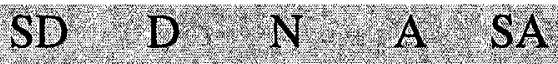
SD $-A, A-S A$ $(x, 1)=$

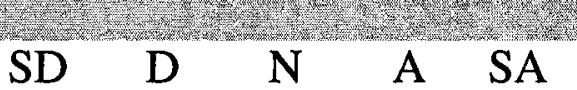
workshops, peer coaching, study groups, joint planning of 


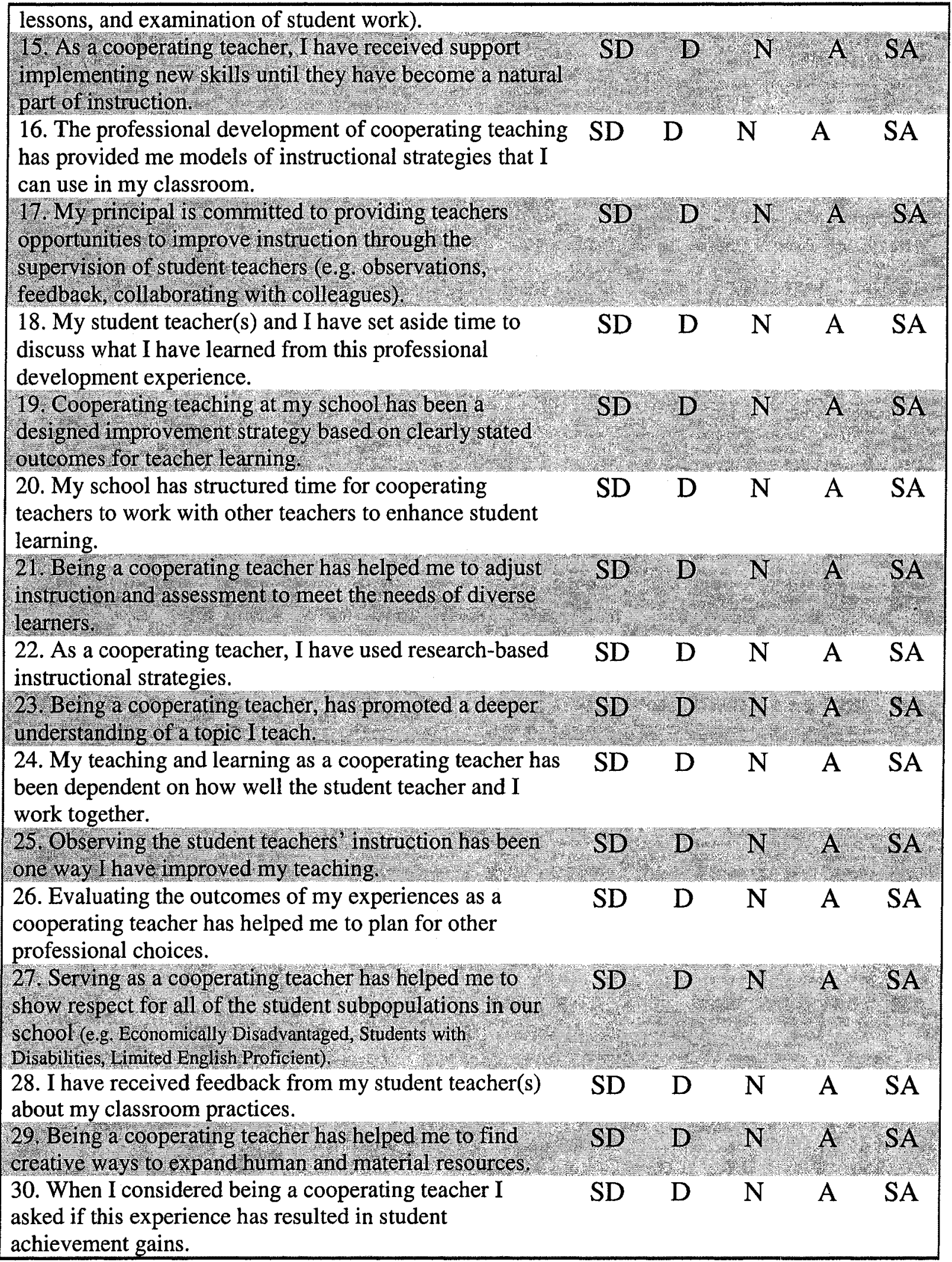




\begin{tabular}{|c|c|c|c|c|c|}
\hline $\begin{array}{l}\text { 31. Being a cooperating teacher has supported my } \\
\text { expectations of high academic achievement for all of our } \\
\text { students. }\end{array}$ & $\mathrm{SD}$ & & & & $\mathrm{SA}$ \\
\hline $\begin{array}{l}\text { 32. Teacher professional development including, serving } \\
\text { as a cooperating teacher, is part of our school's } \\
\text { improvement plan. }\end{array}$ & SD & D & $\mathbf{N}$ & A & SA \\
\hline $\begin{array}{l}\text { 33. As a cooperating teacher, I have learned through a } \\
\text { variety of methods (e.g. hands-on activities, discussion, } \\
\text { dialogue, writing, demonstrations practice with feedback, } \\
\text { group problem solving). }\end{array}$ & $\mathrm{SD}$ & & & & \\
\hline $\begin{array}{l}\text { 34. Being a cooperating teacher has encouraged me to } \\
\text { share the responsibility of achieving school goals. }\end{array}$ & SD & $\mathrm{D}$ & $\mathrm{N}$ & A & SA \\
\hline $\begin{array}{l}\text { 35. Serving as a cooperating teacher has increased my } \\
\text { focus on creating positive relationships with my students. }\end{array}$ & SD & & & & \\
\hline $\begin{array}{l}\text { 36. My principal believes that supervising student } \\
\text { teachers has fostered a school culture that is focused on } \\
\text { instructional improvements. }\end{array}$ & SD & D & $\mathrm{N}$ & A & SA \\
\hline $\begin{array}{l}\text { 37. As a cooperating teacher, my student teacher ( } \mathrm{s} \text { ) and I } \\
\text { have used student data when discussing instruction and } \\
\text { curriculum. }\end{array}$ & SD & & & & \\
\hline $\begin{array}{l}\text { 38. As a cooperating teacher, I have modeled how to } \\
\text { build relationships with students' families. }\end{array}$ & SD & $\mathrm{D}$ & $\mathrm{N}$ & A & SA \\
\hline $\begin{array}{l}\text { 39. Empowering describes my principal's facilitation of } \\
\text { cooperating teaching. }\end{array}$ & $\mathrm{SD}$ & D & & & \\
\hline $\begin{array}{l}\text { 40. School goals have determined how resources are } \\
\text { allotted to support cooperating teachers and student } \\
\text { teachers. }\end{array}$ & SD & $\mathrm{D}$ & $\mathrm{N}$ & $A$ & SA \\
\hline $\begin{array}{l}\text { 41. As a cooperating teacher, my student teacher ( } \mathrm{s} \text { ) and I } \\
\text { have analyzed classroom data with each other to improve } \\
\text { student learning. }\end{array}$ & SD & & & & SA \\
\hline $\begin{array}{l}\text { 42. My prior knowledge and experience have been taken } \\
\text { into consideration when designing my learning } \\
\text { opportunities with the student teacher. }\end{array}$ & SD & D & $\mathbf{N}$ & A & SA \\
\hline $\begin{array}{l}\text { 43. Being a cooperating teacher has been one of the many } \\
\text { types of professional development opportunities (e.g. } \\
\text { study group, action research, observation) that } 1 \text { can } \\
\text { choose from. }\end{array}$ & & $\mathrm{D}$ & & & SA \\
\hline $\begin{array}{l}\text { 44. The professional development of cooperating teaching } \\
\text { has helped me learn about effective student assessment } \\
\text { techniques. }\end{array}$ & SD & D & $\mathrm{N}$ & A & SA \\
\hline $\begin{array}{l}\text { 45. Being a cooperating teacher has helped me to work } \\
\text { with families to support students' learning at home. }\end{array}$ & $\mathrm{SD}$ & & & & $S A$ \\
\hline $\begin{array}{l}\text { 46. The student teacher (s) and I have had regularly } \\
\text { examined student work with each other. }\end{array}$ & SD & D & $N$ & A & SA \\
\hline 47. At iny school, we have adopted serving as a & $\mathrm{SD}$ & D & $\mathrm{N}$ & A & SA \\
\hline
\end{tabular}


cooperating teacher as an option for teachers long enough to see if changes in instructional practice and student performance occur.

48. Being a cooperating teacher has supported my

SD $\quad \mathrm{D} \quad \mathrm{N} \quad \mathrm{A} \quad \mathrm{SA}$ training on curriculum and instruction for students at different levels of learning.

49. The student teacher $(\mathrm{s})$ and I have been engaged in conversations about instruction and student learning.

Scale

$\mathrm{SD}=$ Strongly Disagree $\quad \mathrm{D}=$ Disagree $\quad \mathrm{N}=$ Neutral $\quad \mathrm{A}=$ Agree $\quad \mathrm{SA}=$ Strongly Agree

Thank you for your time and willingness in completing this survey. Please use the enclosed envelope for returning this form. 
Appendix C

Pre-Contact Letter 
Letter on William and Mary Letterhead

February 21, 2007

Dear Cooperating Teacher,

I am soliciting your help and expertise in a study of cooperating teachers. In about a week, Trina Spencer, a doctoral candidate, will send you a survey entitled, "Cooperating Teachers and Professional Development." The intent of her study is to determine how serving as a cooperating teacher may contribute to an individual's professional development.

The survey will take approximately 20 to 30 minutes to complete. The survey is anonymous and your responses will be confidential. I anticipate that Trina's study may add to our knowledge and understanding of the experiences of cooperating teachers.

Thank you in advance for your cooperation. If you have questions concerning this study, Trina may be contacted by e-mail at $\mathbf{x x x}$.

Sincerely,

Christopher R. Gareis, Ed. D.

Assistant Professor of Educational Leadership

Clinical Faculty Program Director

The College of William and Mary

THIS PROJECT WAS FOUND TO COMPLY WITH APPROPRIATE ETHICAL STANDARDS AND WAS EXEMPTED FROM THE NEED FOR FORMAL REVIEW BY THE COLLEGE OF WILLIAM AND MARY PROTECTION OF HUMAN SUBJECTS COMMITTEE (Phone 757-221-3966) ON 2007-02-06 AND EXPIRES ON 2008-02-06. You are required to notify Dr. Ward, chair of the EDIRC, at 757-221-2358 (EDIRC-L@ wm.edu) and Dr. Deschenes, chair of the PHSC at 757-221-2778 (PHSC-L@wm.edu) if any issues arise during this study. 
Appendix D

Survey Cover Letter and Survey Reminder 


\section{Letter on William and Mary Letterhead} Survey Cover Letter

February 28, 2007

Dear Cooperating Teacher,

A week ago, hopefully you received a letter from Dr. Chris Gareis about my study on cooperating teachers. My research study will focus on how cooperating teaching may contribute to an individual's professional development. As a graduate student, my involvement with the Clinical Faculty program at the College of William and Mary led to this interest on cooperating teachers.

Please assist me by completing the attached survey that has been adopted from the National Staff Development Council (NSDC). It will take approximately 20 to 30 minutes to complete. The survey is intended to measure how supervising student teachers affect an individual's professional development. Your input will add to limited data on this topic and help us discover how this experience contributes to teacher learning.

Your participation is voluntary and confidential. You will not be personally identified in the study. Use the self-addressed stamped envelope and return the survey by March 14, 2007. Please keep the dollar as a token of my appreciation for participating in this study.

If you wish to receive this study's results, send me an e-mail (xx) with your contact information. Questions pertaining to the survey may also be sent to me.

Thank you in advance for your assistance and cooperation.

Sincerely,

Trina L. Spencer

Doctoral Candidate

College of William and Mary

THIS PROJECT WAS FOUND TO COMPLY WITH APPROPRIATE ETHICAL STANDARDS AND WAS EXEMPTED FROM THE NEED FOR FORMAL REVIEW BY THE COLLEGE OF WILLIAM AND MARY PROTECTION OF HUMAN SUBJECTS COMMITTEE (Phone 757-221-3966) ON 2007-02-06 AND EXPIRES ON 2008-02-06. You are required to notify Dr. Ward, chair of the EDIRC, at 757-221-2358 (EDIRC-L@wm.edu) and Dr. Deschenes, chair of the PHSC at 757-221-2778 (PHSC-L@wm.edu) if any issues arise during this study. 
Appendix D

Thank you note and reminder postcard

Dear Cooperating Teacher,

Thank you for completing the survey on cooperating teaching and professional development. I appreciate your willingness and the time taken from your busy schedule.

If you have not returned the survey, please do so by Wednesday, March 14, 2007. Your participation is voluntary and your responses will be confidential.

Sincerely,

Trina Spencer

Doctoral Candidate

College of William and Mary

THIS PROJECT WAS FOUND TO COMPLY WITH APPROPRIATE ETHICAL STANDARDS AND WAS EXEMPTED FROM THE NEED FOR FORMAL REVIEW BY THE COLLEGE OF WILLIAM AND MARY PROTECTION OF HUMAN SUBJECTS COMMITTEE (Phone 757-221-3966) ON 2007-02-06 AND EXPIRES ON 2008-02-06. You are required to notify Dr. Ward, chair of the EDIRC, at 757-221-2358 (EDIRC-L@ wm.edu) and Dr. Deschenes, chair of the PHSC at 757-221-2778 (PHSC-L@wm.edu) if any issues arise during this study. 
Appendix E

Survey Item Results 
Results by question

\begin{tabular}{|c|c|c|c|c|c|c|c|}
\hline $1=$ Strongly Disagree & $2=$ Disagree & \multicolumn{2}{|c|}{$3=$ Neutral } & $4=$ Agree & & \multicolumn{2}{|c|}{$5=$ Strongly Agree } \\
\hline & $\begin{array}{c}\text { NSDC } \\
\text { Standard } \\
\text { \&Category }\end{array}$ & $N$ & Missing & Min. & Max. & Mean & Std. Dev \\
\hline $\begin{array}{l}\text { 1. My principal believes } \\
\text { that teacher learning } \\
\text { through cooperating } \\
\text { teaching is essential for } \\
\text { achieving our school } \\
\text { goals. }\end{array}$ & $\begin{array}{l}\text { Leadership } \\
\text { Context }\end{array}$ & 178 & 3 & 1 & 5 & 3.91 & .904 \\
\hline $\begin{array}{l}\text { 2. My student teacher(s) } \\
\text { has helped me think } \\
\text { about implementing new } \\
\text { instructional practices at } \\
\text { our school. }\end{array}$ & $\begin{array}{l}\text { Resources } \\
\text { Context }\end{array}$ & 181 & 1 & 1 & 5 & 4.09 & .770 \\
\hline $\begin{array}{l}\text { 3. I have evaluated what } \\
\text { I would like to gain from } \\
\text { this experience prior to } \\
\text { the student teacher(s) } \\
\text { arrival. }\end{array}$ & $\begin{array}{l}\text { Evaluation } \\
\text { Process }\end{array}$ & 181 & 2 & 1 & 5 & 3.68 & .854 \\
\hline $\begin{array}{l}\text { 4. As a cooperating } \\
\text { teacher I have used } \\
\text { educational research to } \\
\text { select school programs. }\end{array}$ & $\begin{array}{l}\text { Research based } \\
\text { Process }\end{array}$ & 180 & 1 & 1 & 5 & 3.49 & .937 \\
\hline $\begin{array}{l}\text { 5. As a cooperating } \\
\text { teacher I have had } \\
\text { opportunities to practice } \\
\text { the new skills that I have } \\
\text { gained through this } \\
\text { experience. }\end{array}$ & $\begin{array}{l}\text { Learning } \\
\text { Process }\end{array}$ & 180 & 1 & 2 & 5 & 4.08 & .651 \\
\hline $\begin{array}{l}\text { 6. Being a cooperating } \\
\text { teacher has helped me to } \\
\text { learn effective ways to } \\
\text { work with others }\end{array}$ & $\begin{array}{l}\text { Collaboration } \\
\text { Process }\end{array}$ & 181 & 0 & 2 & 5 & 4.18 & .679 \\
\hline $\begin{array}{l}\text { 7. Being a cooperating } \\
\text { teacher has provided me } \\
\text { the opportunity to gain a } \\
\text { deeper understanding of } \\
\text { the subjects I teach. }\end{array}$ & $\begin{array}{l}\text { Quality } \\
\text { Teaching } \\
\text { Content }\end{array}$ & 181 & $\overline{0}$ & 1 & 5 & 3.87 & .945 \\
\hline
\end{tabular}




\begin{tabular}{|c|c|c|c|c|c|c|c|}
\hline $\begin{array}{l}\text { 8. Being a cooperating } \\
\text { teacher has provided me } \\
\text { the opportunity to learn } \\
\text { how to involve families } \\
\text { in their children's } \\
\text { education. }\end{array}$ & $\begin{array}{c}\text { Family } \\
\text { Involvement } \\
\text { Content }\end{array}$ & 181 & 0 & 1 & 5 & 2.83 & .860 \\
\hline $\begin{array}{l}\text { 9. The student teacher } \\
\text { (s) and I have met } \\
\text { regularly to discuss } \\
\text { ways to improve } \\
\text { teaching and learning. }\end{array}$ & $\begin{array}{c}\text { Learning } \\
\text { Communities } \\
\text { Context }\end{array}$ & 180 & 1 & 2 & 5 & 4.57 & .560 \\
\hline $\begin{array}{l}\text { 10. Being a cooperating } \\
\text { teacher has provided me } \\
\text { the opportunity to learn } \\
\text { how to use technology } \\
\text { to enhance my } \\
\text { instruction. }\end{array}$ & $\begin{array}{c}\text { Resources } \\
\text { Context }\end{array}$ & 181 & 0 & 2 & 5 & 3.71 & .952 \\
\hline $\begin{array}{l}\text { 11. Serving as a } \\
\text { cooperating teacher, has } \\
\text { supported my ability to } \\
\text { learn how to use data1 to } \\
\text { assess student learning } \\
\text { needs. }\end{array}$ & $\begin{array}{c}\text { Data Driven } \\
\text { Process }\end{array}$ & 181 & 0 & 1 & 5 & 3.27 & .971 \\
\hline $\begin{array}{l}\text { 12. As a cooperating } \\
\text { teacher, I have used } \\
\text { several sources to } \\
\text { evaluate } 1 \text { the } \\
\text { effectiveness of this } \\
\text { experlience on student } \\
\text { learning (e.g. classroom } \\
\text { observation, teacher } \\
\text { surveys, conversations } \\
\text { with principals or } \\
\text { coaches). }\end{array}$ & $\begin{array}{l}\text { Evaluation } \\
\text { Process }\end{array}$ & 181 & 0 & 1 & 5 & 3.94 & .765 \\
\hline $\begin{array}{l}\text { 13. One criterion that I } \\
\text { considered in my } \\
\text { decision to participate as } \\
\text { a cooperating teacher } \\
\text { was based on research } \\
\text { that shows evidence of } \\
\text { improved student } \\
\text { performance. }\end{array}$ & $\begin{array}{l}\text { Research based } \\
\text { Process }\end{array}$ & 181 & 0 & 1 & 5 & 2.83 & 1.003 \\
\hline
\end{tabular}




\begin{tabular}{|c|c|c|c|c|c|c|c|}
\hline $\begin{array}{l}\text { 14. As a cooperating } \\
\text { teacher, my learning has } \\
\text { been supported through } \\
\text { a combination of } \\
\text { strategies (e.g. } \\
\text { workshops, peer } \\
\text { coaching, study groups, } \\
\text { joint planning of } \\
\text { lessons, and examination } \\
\text { of student work). }\end{array}$ & $\begin{array}{l}\text { Design and } \\
\text { Strategies } \\
\text { Process }\end{array}$ & 181 & 0 & 2 & 5 & 3.90 & .820 \\
\hline $\begin{array}{l}\text { 15. As a cooperating } \\
\text { teacher, I have received } \\
\text { support implementing } \\
\text { new skills until they } \\
\text { have become a natural } \\
\text { part of instruction. }\end{array}$ & $\begin{array}{l}\text { Learning } \\
\text { Process }\end{array}$ & 180 & 1 & 1 & 5 & 3.26 & .855 \\
\hline $\begin{array}{l}\text { 16. The professional } \\
\text { development of } \\
\text { cooperating teaching has } \\
\text { provided me models of } \\
\text { instructional strategies } \\
\text { that I can use in my } \\
\text { classroom. }\end{array}$ & $\begin{array}{l}\text { Quality } \\
\text { Teaching } \\
\text { Content }\end{array}$ & 180 & 1 & 1 & 5 & 3.73 & .851 \\
\hline $\begin{array}{l}\text { 17. My principal is } \\
\text { committed to providing } \\
\text { teachers opportunities to } \\
\text { improve instruction } \\
\text { through the supervision } \\
\text { of student teachers (e.g. } \\
\text { observations, feedback, } \\
\text { collaborating with } \\
\text { colleagues). }\end{array}$ & $\begin{array}{c}\text { Leadership } \\
\text { Context }\end{array}$ & 180 & 1 & 1 & 5 & 3.98 & .862 \\
\hline $\begin{array}{l}\text { 18. My student } \\
\text { teacher(s) and I have set } \\
\text { aside time to discuss } \\
\text { what I have learned } \\
\text { from this professional } \\
\text { development experience. }\end{array}$ & $\begin{array}{c}\text { Evaluation } \\
\text { Process }\end{array}$ & 180 & 1 & 1 & 5 & 3.67 & 1.029 \\
\hline $\begin{array}{l}\text { 19. Cooperating } \\
\text { teaching at my school } \\
\text { has been a designed } \\
\text { improvement strategy } \\
\text { based on clearly stated } \\
\text { outcomes for teacher } \\
\text { learning. }\end{array}$ & $\begin{array}{c}\text { Design and } \\
\text { Strategies } \\
\text { Process }\end{array}$ & 180 & 1 & 1 & 5 & 3.07 & .957 \\
\hline
\end{tabular}




\begin{tabular}{|c|c|c|c|c|c|c|c|}
\hline $\begin{array}{l}20 . \text { My school has } \\
\text { structured time for } \\
\text { cooperating teachers to } \\
\text { work with other teachers } \\
\text { to enhance student } \\
\text { learning. }\end{array}$ & $\begin{array}{l}\text { Collaboration } \\
\text { Process }\end{array}$ & 181 & 0 & 1 & 5 & 3.05 & 1.199 \\
\hline $\begin{array}{l}\text { 21. Being a cooperating } \\
\text { teacher has helped me to } \\
\text { adjust instruction and } \\
\text { assessment to meet the } \\
\text { needs of diverse } \\
\text { learners. }\end{array}$ & $\begin{array}{l}\text { Equity } \\
\text { Content }\end{array}$ & 178 & 4 & 1 & 5 & 3.60 & .941 \\
\hline $\begin{array}{l}\text { 22. As a cooperating } \\
\text { teacher, I have used } \\
\text { research-based } \\
\text { instructional strategies. }\end{array}$ & $\begin{array}{l}\text { Quality } \\
\text { Teaching } \\
\text { Content }\end{array}$ & 181 & 0 & 2 & 5 & 4.08 & .752 \\
\hline $\begin{array}{l}\text { 23. Being a cooperating } \\
\text { teacher, has promoted a } \\
\text { deeper understanding of } \\
\text { a topic I teach. }\end{array}$ & $\begin{array}{l}\text { Learning } \\
\text { Process }\end{array}$ & 180 & 1 & 1 & 5 & 3.74 & .874 \\
\hline $\begin{array}{l}\text { 24. My teaching and } \\
\text { learning as a cooperating } \\
\text { teacher has been } \\
\text { dependent on how well } \\
\text { the student teacher and I } \\
\text { work together. }\end{array}$ & $\begin{array}{l}\text { Collaboration } \\
\text { Process }\end{array}$ & 181 & 0 & 1 & 5 & 3.65 & 1.036 \\
\hline $\begin{array}{l}25 . \text { Observing the } \\
\text { student teachers' } \\
\text { instruction has been one } \\
\text { way I have improved my } \\
\text { teaching. }\end{array}$ & $\begin{array}{c}\text { Learning } \\
\text { Communities } \\
\text { Context }\end{array}$ & 181 & 0 & $\overline{1}$ & 5 & 4.02 & .756 \\
\hline $\begin{array}{l}\text { 26. Evaluating the } \\
\text { outcomes of my } \\
\text { experiences as a } \\
\text { cooperating teacher has } \\
\text { helped me to plan for } \\
\text { other professional } \\
\text { choices. }\end{array}$ & $\begin{array}{c}\text { Evaluation } \\
\text { Process }\end{array}$ & 181 & 0 & 1 & 5 & 3.58 & .830 \\
\hline $\begin{array}{l}27 . \text { Serving as a } \\
\text { cooperating teacher has } \\
\text { helped me to show } \\
\text { respect for all of the } \\
\text { student subpopulations } \\
\text { in our school (e.g. } \\
\text { Economically }\end{array}$ & $\begin{array}{c}\text { Equity } \\
\text { Content }\end{array}$ & 180 & 1 & 1 & 5 & 3.20 & .861 \\
\hline
\end{tabular}




\begin{tabular}{|c|c|c|c|c|c|c|c|}
\hline $\begin{array}{l}\text { Disadvantaged, Students } \\
\text { with Disabilities, } \\
\text { Limited English } \\
\text { Proficient). }\end{array}$ & & & & & & & \\
\hline $\begin{array}{l}\text { 28. I have received } \\
\text { feedback from my } \\
\text { student teacher(s) about } \\
\text { my classroom practices. }\end{array}$ & $\begin{array}{l}\text { Learning } \\
\text { Communities } \\
\text { Context }\end{array}$ & 181 & 0 & 1 & 5 & 3.76 & .865 \\
\hline $\begin{array}{l}\text { 29. Being a cooperating } \\
\text { teacher has helped me to } \\
\text { find creative ways to } \\
\text { expand human and } \\
\text { material resources. }\end{array}$ & $\begin{array}{c}\text { Resources } \\
\text { Context }\end{array}$ & 180 & 1 & 1 & 5 & 3.71 & .844 \\
\hline $\begin{array}{l}30 . \text { When I considered } \\
\text { being a cooperating } \\
\text { teacher I asked if this } \\
\text { experience has resulted } \\
\text { in student achievement } \\
\text { gains. }\end{array}$ & $\begin{array}{l}\text { Research based } \\
\text { Process }\end{array}$ & 181 & 0 & 1 & 5 & 3.06 & 1.055 \\
\hline $\begin{array}{l}31 . \text { Being a cooperating } \\
\text { teacher has supported } \\
\text { my expectations of high } \\
\text { academic achievement } \\
\text { for all of our students. }\end{array}$ & $\begin{array}{l}\text { Equity } \\
\text { Content }\end{array}$ & 179 & 3 & 1 & 5 & 3.92 & .771 \\
\hline $\begin{array}{l}\text { 32. Teacher professional } \\
\text { development including, } \\
\text { serving as a cooperating } \\
\text { teacher, is part of our } \\
\text { school's improvement } \\
\text { plan. }\end{array}$ & $\begin{array}{l}\text { Design and } \\
\text { Strategies } \\
\text { Process }\end{array}$ & 178 & 4 & 1 & 5 & 3.33 & 1.044 \\
\hline $\begin{array}{l}\text { 33. As a cooperating } \\
\text { teacher, I have learned } \\
\text { through a variety of } \\
\text { methods (e.g. hands-on } \\
\text { activities, discussion, } \\
\text { dialogue, writing, } \\
\text { demonstrations practice } \\
\text { with feedback, group } \\
\text { problem solving). }\end{array}$ & $\begin{array}{l}\text { Learning } \\
\text { Process }\end{array}$ & 179 & 2 & 2 & 5 & 3.94 & .770 \\
\hline $\begin{array}{l}\text { 34. Being a cooperating } \\
\text { teacher has encouraged } \\
\text { me to share the } \\
\text { responsibility of } \\
\text { achieving school goals. }\end{array}$ & $\begin{array}{l}\text { Collaboration } \\
\text { Process }\end{array}$ & 180 & 1 & 2 & 5 & 3.83 & .795 \\
\hline
\end{tabular}




\begin{tabular}{|c|c|c|c|c|c|c|c|}
\hline $\begin{array}{l}35 . \text { Serving as a } \\
\text { cooperating teacher has } \\
\text { increased my focus on } \\
\text { creating positive } \\
\text { relationships with my } \\
\text { students. }\end{array}$ & $\begin{array}{l}\text { Equity } \\
\text { Content }\end{array}$ & 179 & 2 & 1 & 5 & 3.84 & .842 \\
\hline $\begin{array}{l}\text { 36. My principal } \\
\text { believes that supervising } \\
\text { student teachers has } \\
\text { fostered a school culture } \\
\text { that is focused on } \\
\text { instructional } \\
\text { improvements. }\end{array}$ & $\begin{array}{l}\text { Leadership } \\
\text { Context }\end{array}$ & 179 & 2 & 1 & 5 & 3.68 & .865 \\
\hline $\begin{array}{l}\text { 37. As a cooperating } \\
\text { teacher, my student } \\
\text { teacher (s) and I have } \\
\text { used student data when } \\
\text { discussing instruction } \\
\text { and curriculum. }\end{array}$ & $\begin{array}{c}\text { Data Driven } \\
\text { Process }\end{array}$ & 181 & 0 & 2 & 5 & 4.03 & .718 \\
\hline $\begin{array}{l}\text { 38. As a cooperating } \\
\text { teacher, I have modeled } \\
\text { how to build } \\
\text { relationships with } \\
\text { students' families. }\end{array}$ & $\begin{array}{c}\text { Family } \\
\text { Involvement } \\
\text { Content }\end{array}$ & 179 & 2 & 2 & 5 & 4.17 & .666 \\
\hline $\begin{array}{l}\text { 39. Empowering } \\
\text { describes my principal's } \\
\text { facilitation of } \\
\text { cooperating teaching. }\end{array}$ & $\begin{array}{l}\text { Leadership } \\
\text { Context }\end{array}$ & 179 & 2 & 1 & 5 & 3.44 & .912 \\
\hline $\begin{array}{l}\text { 40. School goals have } \\
\text { determined how } \\
\text { resources are allotted to } \\
\text { support cooperating } \\
\text { teachers and student } \\
\text { teachers. }\end{array}$ & $\begin{array}{c}\text { Resources } \\
\text { Context }\end{array}$ & 179 & 2 & 1 & 5 & 3.03 & .803 \\
\hline $\begin{array}{l}\text { 41. As a cooperating } \\
\text { teacher, my student } \\
\text { teacher (s) and I have } \\
\text { analyzed classroom data } \\
\text { with each other to } \\
\text { improve student } \\
\text { learning. }\end{array}$ & $\begin{array}{c}\text { Data Driven } \\
\text { Process }\end{array}$ & 181 & 0 & 2 & 5 & 4.02 & .760 \\
\hline
\end{tabular}




\begin{tabular}{|c|c|c|c|c|c|c|c|}
\hline $\begin{array}{l}\text { 42. My prior knowledge } \\
\text { and experience have } \\
\text { been taken into } \\
\text { consideration when } \\
\text { designing my learning } \\
\text { opportunities with the } \\
\text { student teacher. }\end{array}$ & $\begin{array}{l}\text { Design and } \\
\text { Strategies } \\
\text { Process }\end{array}$ & 181 & 0 & 2 & 5 & 4.32 & .594 \\
\hline $\begin{array}{l}\text { 43. Being a cooperating } \\
\text { teacher has been one of } \\
\text { the many types of } \\
\text { professional } \\
\text { development } \\
\text { opportunities (e.g., study } \\
\text { group, action research, } \\
\text { observation) that I can } \\
\text { choose from. }\end{array}$ & $\begin{array}{l}\text { Learning } \\
\text { Process }\end{array}$ & 181 & 0 & 2 & 5 & 4.15 & .698 \\
\hline $\begin{array}{l}\text { 44. The professional } \\
\text { development of } \\
\text { cooperating teaching has } \\
\text { helped me learn about } \\
\text { effective student } \\
\text { assessment techniques. }\end{array}$ & $\begin{array}{l}\text { Quality } \\
\text { Teaching } \\
\text { Content }\end{array}$ & 180 & 1 & 1 & 5 & 3.63 & .838 \\
\hline $\begin{array}{l}\text { 45. Being a cooperating } \\
\text { teacher has helped me to } \\
\text { work with families to } \\
\text { support students' } \\
\text { learning at home. }\end{array}$ & $\begin{array}{c}\text { Family } \\
\text { Involvement } \\
\text { Content }\end{array}$ & 179 & 2 & 1 & 5 & 3.02 & .887 \\
\hline $\begin{array}{l}\text { 46. The student teacher } \\
\text { (s) and I have had } \\
\text { regularly examined } \\
\text { student work with each } \\
\text { other. }\end{array}$ & $\begin{array}{c}\text { Learning } \\
\text { Communities } \\
\text { Context }\end{array}$ & 179 & 2 & 2 & 5 & 4.26 & .600 \\
\hline $\begin{array}{l}47 . \text { At my school, we } \\
\text { have adopted serving as } \\
\text { a cooperating teacher as } \\
\text { an option for teachers } \\
\text { long enough to see if } \\
\text { changes in instructional } \\
\text { practice and student } \\
\text { performance occur. }\end{array}$ & $\begin{array}{l}\text { Design and } \\
\text { Strategies } \\
\text { Process }\end{array}$ & 179 & 2 & 1 & 5 & 2.84 & .929 \\
\hline $\begin{array}{l}\text { 48. Being a cooperating } \\
\text { teacher has supported } \\
\text { my training on } \\
\text { curriculum and } \\
\text { instruction for students } \\
\text { at different levels of }\end{array}$ & $\begin{array}{c}\text { Equity } \\
\text { Content }\end{array}$ & 181 & 0 & 1 & 5 & 3.75 & .823 \\
\hline
\end{tabular}




\begin{tabular}{|l|c|c|c|c|c|c|c|}
\hline learning. & & & & & & & \\
\hline $\begin{array}{l}\text { 49. The student } \\
\text { teacher(s) and I have } \\
\text { been engaged in } \\
\text { conversations about } \\
\text { instruction and student } \\
\text { learning. }\end{array}$ & $\begin{array}{c}\text { Quality } \\
\text { Teaching } \\
\text { Content }\end{array}$ & 180 & 1 & 2 & 5 & 4.62 & .591 \\
\hline
\end{tabular}

Scale 